\title{
WestVirginiaUniversity
}

THE RESEARCH REPOSITORY @ WVU

Graduate Theses, Dissertations, and Problem Reports

2012

\section{A Question of Life or Death: Suicide and Survival in the Union Army}

Kathleen Anneliese Logothetis

West Virginia University

Follow this and additional works at: https://researchrepository.wvu.edu/etd

\section{Recommended Citation}

Logothetis, Kathleen Anneliese, "A Question of Life or Death: Suicide and Survival in the Union Army" (2012). Graduate Theses, Dissertations, and Problem Reports. 4888.

https://researchrepository.wvu.edu/etd/4888

This Thesis is protected by copyright and/or related rights. It has been brought to you by the The Research Repository @ WVU with permission from the rights-holder(s). You are free to use this Thesis in any way that is permitted by the copyright and related rights legislation that applies to your use. For other uses you must obtain permission from the rights-holder(s) directly, unless additional rights are indicated by a Creative Commons license in the record and/ or on the work itself. This Thesis has been accepted for inclusion in WVU Graduate Theses, Dissertations, and Problem Reports collection by an authorized administrator of The Research Repository @ WVU. For more information, please contact researchrepository@mail.wvu.edu. 


\title{
A Question of Life or Death: Suicide and Survival in the Union Army
}

\author{
Kathleen Anneliese Logothetis
}

\begin{abstract}
Thesis submitted to the Eberly College of Arts and Sciences at West Virginia University
\end{abstract} in partial fulfillment of the requirements for the degree of

Master of Arts

in

History

\author{
Aaron Sheehan-Dean, Ph.D., Chair \\ Brian Luskey, Ph.D. \\ Katherine Aaslestad, Ph.D. \\ Department of History
}

\begin{abstract}
Morgantown, West Virginia
2012
\end{abstract}

Keywords: Civil War; Suicide; Soldier Experience; Union Army Copyright 2012 Kathleen Anneliese Logothetis 


\section{ABSTRACT \\ A Question of Life or Death: Suicide and Survival in the Union Army}

\section{Kathleen Anneliese Logothetis}

Studying the Civil War soldier involves a quest to comprehend how they soldiers understood and managed their war experiences. Under the conditions of soldier life and the horrific violence of Civil War battles, mental trauma and suicide would not be unthinkable consequences. Union soldiers did commit suicide during the war, sometimes in response to the trauma of battle, hospital, or prison camp. However, suicide in fact was a very small percentage of casualties in the Union army, representing less than one percent of the losses during the war.

This thesis examines the dual nature of suicide in the Union army. On one hand, the transformation from civilian into soldier and the traumatic experiences related to military life greatly affected men. The first year of enlistment proved the most difficult, particularly for men between the ages of twenty-six and thirty. One hundred and one cases of suicide are analyzed both contextually and statistically in order to further understand the experience and decisions of the Civil War soldier. On the other hand, the low suicide rate suggests that most soldiers managed their war time experiences. Men relied on a "cultural toolbox" of religious beliefs, established methods of facing and mourning death, ideas about courage and masculinity, and ties to the civilian world to understand and act within their role as a soldier.

By focusing on suicide, the analysis centers on the possibility of failure in negotiating the experience of war, instead of the successes most historians have emphasized. In addition, instead of ideas such as liberty, freedom, and country, soldiers understood their experiences and persevered because of social norms and behaviors. The motivation for suicides as well as the support system which prevented them came from a soldier's interactions as a family and community member, as well as a part of a volunteer army fighting a war. Questions about life and death are not always grandiose; they can come from basic understandings of and connections to one's world. Soldiers felt the impact of both positive and negative influences; using suicide as a focal point allows for an examination of how soldiers negotiated trauma and wartime conditions to survive. 


\section{Table of Contents}

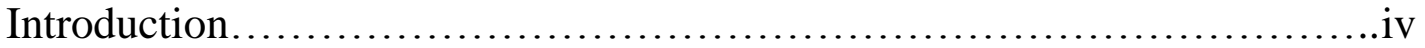

Chapter 1: Prelude to Self-Destruction:

Antebellum Suicide and the Environment of War.....................1

Suicide in the American Mind.......................................2

The Experience of Combat......................................... 12

Mental Stress in the Union Army.....................................19

Chapter 2: "To Be or Not To Be":

Suicide Among Union Soldiers..................................27

Suicides in the Union Army .......................................29

Was Combat Experience Enough to Cause Suicide? ...................50

Chapter 3: "Whether "tis Nobler in the Mind":

The Soldier's "Cultural Toolbox" and Wartime Survival................62

The "Cultural Toolbox" of the Union Soldier.........................64

Conclusion: The "Cultural Toolbox" and Suicide..............................91

Appendix.........................................................97

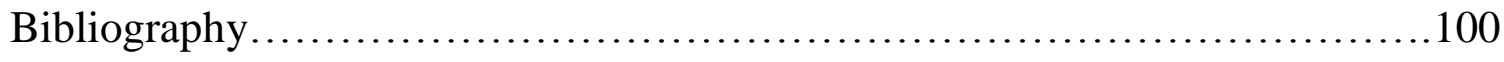




\section{Introduction}

In September 1861, just days after enlisting with the $33^{\text {rd }}$ Illinois Infantry and days before following his unit to the front lines, Henry Johnson drowned himself in a lake. ${ }^{1}$ A wounded soldier lying on Marye's Heights after the Battle of Fredericksburg took his own life to prevent his capture as a prisoner. ${ }^{2}$ In Memphis, an ill soldier "became violently insane" and jumped out a fourth-story window. ${ }^{3}$ Soldiers at Andersonville prison deliberately stepped over the "dead line" hoping to be shot by Confederate guards. ${ }^{4}$ And R. Milton Smiley committed suicide just one month before his regiment mustered out and went home in $1865 .^{5}$ These are not the traditional stories told of death in the Civil War, of battlefield casualties, of dying from the horrific wounds of war, or of the thousands of men who died from disease. These are Union soldiers who, perhaps becoming desperate in their surroundings, took the decision into their own hands to become a casualty of war.

Studying the Civil War soldier involves a quest to comprehend how they understood and managed their war experiences. My research explores the question of

\footnotetext{
${ }^{1}$ Albert O'Connell Marshall, Army Life from a Soldier's Journal: Incidents, Sketches and Record of a Union Soldier's Army Life, in Camp and Field, 1861-1864 (Joliet, IL: A.O. Marshall, 1883. Accessed February 3, 2011, American Civil War Diaries and Letters): 30-31.

2 Thomas H. Evans, "The Cries of the Wounded were Piercing and Horrible," Civil War Times Illustrated 7 (July 1968): 33; George C. Rable, "It Is Well That War Is So Terrible: The Carnage at Fredericksburg," In The Fredericksburg Campaign: Decisions on the Rappahannock, 48-79, edited by Gary Gallagher (Chapel Hill: University of North Carolina Press, 1995): 58.

${ }^{3}$ Charles B. Kimball, History of Battery “A, ” First Illinois Light Artillery Volunteers (Chicago: Cushing Printing Company, 1899. http://babel.hathitrust.org): 51.

${ }^{4}$ Gerald F. Lindermann, Embattled Courage: The Experience of Combat in the American Civil War (New York: The Free Press, 1987): 260; William Marvel, Andersonville: The Last Depot (Chapel Hill: The University of North Carolina Press, 1994): 190.

${ }^{5}$ Illinois. Military and Naval Department, Jasper N. Reece, and Isaac Hughes Elliott, Report of the Adjutant General of the State of Illinois, Volume IV, Containing Reports for the Years 1861-1866 (Springfield, IL: Phillips Bros, State Printers, 1901): 674, GoogleBooks; Terrence J. Winschel, The Civil War Diary of a Common Soldier: William Wiley of the $77^{\text {th }}$ Illinois Infantry (Baton Rouge: Louisiana State University Press, 2001): 175.
} 
whether and why they killed themselves as a result of those experiences. Knowing the conditions of soldier life and the horrific violence of Civil War battles, I expected that the armies would see a relatively large number of suicides during the war years. ${ }^{6}$ Perhaps I also unconsciously grounded this assumption in the experience of the modern military where suicide is a far more frequent occurrence. Veterans from our recent armed conflicts, particularly the Gulf Wars and the conflicts in the Middle East, exhibit high rates of suicide and mental/behavioral issues highlighted by the media. In addition to my own preconceived notions, a survey of antebellum reactions to and discussions of suicide also implied a heightened awareness and growing fear of increased suicide rates.

What I found, however, was that suicide in fact was a very small percentage of casualties in the Union army, representing less than one percent of the losses during the war. $^{7}$ But these cases can provide insight into what soldiers experienced and how they managed their military service during the Civil War. The environment of war, the sights, sounds, feelings, and actions of military service had a definite impact on soldiers. Most were able to survive despite experiencing mental stress, but those who could not withstand the trauma of their service provide a new opportunity to understand the Civil War soldier. The low suicide rate required that I investigate why more cases did not happen and examine what elements restrained soldiers from resorting to desperate action, in addition to the suicides and their causes. As a result, the chapters of this thesis focus on two sides of the same story.

Chapter one delves into the world of the Civil War soldier by discussing the perceptions of suicide in antebellum society and the experience of warfare. Historically,

\footnotetext{
${ }^{6}$ I narrowed my focus to the Union army due to available sources.

${ }^{7}$ For full explanation of the suicide rate see page 27 .
} 
Americans viewed suicide negatively, but in the antebellum years increased discussion of the topic created shifts as the act of suicide was criminalized, sentimentalized, politicized, and medicalized. Becoming a soldier and entering the world of war challenged men's identity and worldview. While most men survived their time in the army, evidence of mental stress and trauma indicates that their experiences had negative effects upon their minds and bodies. This study provides the base for the contextual and statistical analysis in chapter two of details derived from suicides in the Union Army. From these cases I make links between suicide and certain stressors in war (namely battle, injury or illness, and being a prisoner of war), age, and length of service. This chapter concludes by placing Civil War suicides within modern suicide theories; this helps explain why some men committed suicide, and it also begins the discussion of why more men did not.

The third chapter addresses the opposite side of the suicide question: analyzing why the suicide rate was so low among Union soldiers. Civil War soldiers maintained a mental support system of cultural ideas which I label the "cultural toolbox." These "tools" helped soldiers manage and act within the environment of war. Primarily, soldiers relied on religious beliefs, societal norms of dealing with death, concepts of courage and masculinity, and connections with family at home and comrades at war. According to Thomas Joiner's theory of suicide, "thwarted belongingness" was one of three components to a serious suicide threat; feeling connected to others prevented this from developing. Union soldiers maintained connections with fellow soldiers through the bonds of comradeship and the common experiences of war, family members through letters, and society at large by utilizing understood social behaviors that reminded them 
of their civilian identity. Placing the maintenance of such connections within Thomas Joiner's theory possibly explains the low suicide rate seen in the Union Army.

Taking suicide as a focal point in studying the Civil War soldier weaves together several topics that pervious scholars have addressed separately. Societal reactions to suicide, the experience of war, the psychology of suicide, and the cultural expectations of nineteenth-century America all combine in the stories of individuals who made the decision to take their lives while fighting as soldiers in the Union army. While none of these subjects are new, there has been no previous attempt to understand them by studying military suicide. Three historians are currently doing work on nineteenth century suicides outside the military: David Silkenat's recent book on Civil War suicide focuses on the changes in how North Carolinian society felt about the subject, Terri Snyder has researched suicide in the context of slavery, and Diane M. Sommerville's research focuses on post-war suicides in Confederate veterans with connections to financial failure. Drew Gilpin Faust and Mark S. Schantz have both researched death during the Civil War era; even though neither work containes a discussion of suicide, both influenced my understandings of a soldier's civilian-world view of death. In addition, Richard J. Bell writes on the discussions of suicide in antebellum society and argues that antebellum Americans used suicide in discussing many social concerns and the increased dialogue created the perception of a rising suicide epidemic. His work implies that there would be a larger suicide rate during the war because soldiers would have been immersed in these discussions before the war. My work builds off of these historians, and others, to renew the conversation about how Civil War soldiers survived by looking through the lens of who made the decision to commit suicide. 
By focusing on suicide, the analysis centers on the possibility of failure in negotiating the experience of war, instead of the successes most historians have emphasized. My analysis also differs in method from some previous scholars, particularly James McPherson who argues for a more ideological approach to soldiers' motivations and support systems. Instead of ideas such as liberty, freedom, and country, I found that soldiers based their experiences more in social norms and behaviors. My approach is in ways more cultural, but primarily more grounded in human experience. The motivation for suicides as well as the support system which prevented them came from a soldier's interactions as a family and community member, as well as a part of a volunteer army fighting a war. Questions about life and death are not always grandiose; they can come from basic understandings of and connections to one's world. Soldiers felt the impact of both positive and negative influences; using suicide as a focal point allows for an examination of how soldiers negotiated trauma and wartime conditions to survive. 


\section{Chapter 1}

\section{Prelude to Self-Destruction:}

\section{Antebellum Suicide and the Environment of War}

Lieut. Fred Starkey committed suicide at his quarters at Camp Relief; no reason is known for the act, and it is supposed that he was temporarily insane. He was buried in the cemetery at the Soldier's Home on the $14^{\text {th }}$.

A sad occurrence took place in our company a few days since which has cast a gloom over every one. Private Saml. Lindsay committed suicide by shooting himself through the brain with a revolver while laboring under temporary insanity; the ball entering the forehead passed down through the brain and came out the left ear. He was married but a few weeks before enlisting and leaves a young wife and a large circle of friends to mourn his loss. He was a great favorite in the company. In the mail which brought your letter came two for him addressed [sic] in his wifes hand writing; one of them mailed the day he died She little thought then the fate which awaited her. ${ }^{2}$

They brought us the sad news that Henry Johnson, a fine, intelligent young man who had been left in the hospital at Camp Butler, had committed suicide by drowning himself in the small lake at the place. This sad information seemed too incredible for belief. I saw had $[s i c]$ a talk with him just before we came away and he appeared to be in good spirits. He said that he was gaining nicely and would be with us in a few days. When I expressed my regret that he could not go with us he replied in a happy, lively manner and laughingly anticipated the pleasant time he would have going down to Missouri in a nice, comfortable passenger coach, while we would have to go in crowded freight cars ... Some new, discouraging memories and thoughts must have occurred to the young soldier after we came away or he would never have sacrificed his life so vainly. ${ }^{3}$

The words of soldiers who witnessed and wrote about suicides among their peers provide almost all the information we have about soldiers who killed themselves. The soldiers who committed suicide are silent—all we have are records and the accounts of other people. Thus our investigation must also be from the outside looking in, searching

\footnotetext{
${ }^{1}$ Thomas West Smith, The Story of a Cavalry Regiment, "Scotts' 900, ”Eleventh New York Cavalry, From the St. Lawrence River to the Gulf of Mexico, 1861-1865 (Chicago: W.B. Conkey Co., 1897): 73.

${ }^{2}$ Sally Andrews Earnest, ed., Letters of Stephen Tuppet Andrews of the $85^{\text {th }}$ New York Volunteers, Company F, to Miss Margaret Little, Franklinville, New York, August 28, 1861 to March 28, 1865 during the Civil War (Pittsboro, NC: The Town House Press, 1998): 97.

${ }^{3}$ Albert O'Connell Marshall, "Memoir of Albert O’Connell Marshall," 30-31.
} 
for answers about very private matters in sources that have no access to the private thoughts and decisions of a suicidal comrade. More importantly though, the words of soldiers faced with the suicide of a fellow regiment or company member expose their thoughts on suicide and the place of suicide in their society. Each of these accounts contains expressions of sadness, sympathy, or disapproval, and each exhibits different levels of understanding. Reactions by outsiders to soldier suicides varied between sympathy and understanding and confusion and condemnation. A wide range of perspectives on suicide appear through the years of the war, although some men may have developed a sense of understanding during the conflict. The medicalization of suicide in the antebellum period began the transformation of suicide from irrational sin to mental process; however, a soldier's understanding of a suicide built off of the shared experience of war.

This research delves into the experiences of suicidal soldiers, to understand their decisions to kill themselves. It also examines the perspective of the other soldiers-to answer why some did commit suicide but so many others did not. Both sets of soldiers were products of a society with definite, although shifting, views of suicide. This chapter will first examine how antebellum society thought about and used suicide. That context opens up analysis of the experience of the war and how it affected the soldiers fighting it, primarily understanding mental stress created by the war and how it influenced some soldiers to kill themselves.

\section{Suicide in the American Mind}

Understandings of and reactions to suicide underwent a transformation during the antebellum period, primarily concerning the criminalization, sentimentalization, 
politicization, and medicalization of suicide. The public discourse and understandings of suicide developed in the years before the war shaped what Civil War soldiers believed about the topic. Americans' beliefs about suicide developed from early English and religious roots where suicide was a crime and attempted or unsuccessful suicides could be tried and punished as felons. Colonial laws about suicide varied due to different levels of adherence to the laws of England. In most cases, however, there was little difficulty in seeing suicide as an offense against society, family, and God. In some colonies those who succeeded in killing themselves were denied a Christian burial, buried at a crossroads under a pile of stones with a stake driven through their chest, and had all of their goods seized. These severe punishments often led families to hide the suicides of family members, and coroners' juries had to be satisfied with the existence of both intention and motive to rule a suicide felo de se, or a criminal action. There were a few exceptions, such as a physical illness in which the severity of pain could be proven, where a jury might rule a suicide non compos mentis, meaning "not of sound mind," and reduce the punishment. Increasingly, melancholy was accepted in non compos mentis rulings. Religiously, Puritans saw suicide as an act of the Devil and this belief carried over to the early Massachusetts Bay Colony which treated suicides as both a criminal and a sinner. While Puritan leaders preached that suicide was Satan tempting people to reject God, they also saw suicide as an individual choice so Massachusetts punished only those who committed suicide, not their families. Some colonies had softer laws against suicide, and by the late-seventeenth century and early-eighteenth century the common law excuses for suicide had broadened in most areas. Revolutionary trends furthered the process of separating suicide from criminality by emphasizing individuality and personal 
freedom. Applying harsh punishments became increasingly more difficult by investigations to prove that the suicidal person knew the consequences and still voluntarily killed themselves; without knowing the mindset of the person, proving guilt was nearly impossible. ${ }^{4}$

In Enlightenment Europe suicide became a subject of public debate and philosophers put forth opinions both in support of and in opposition to suicide. Traditionalists concerned about a perceived rise in suicide rates attacked deism, freethinking, and the philosophical spirit with arguments that suicide was a crime against God, society, and law. Not only did suicide go against all reason, human nature, and divine will, but it was an act of cowardice. La religion Vengée in 1757 claimed suicide resulted from weakness or madness. ${ }^{5}$ The Dictionaire de Trivoux defined suicide as "the system of cowards, who have neither the patience to endure themselves, not the courage to bear the burden of a misfortune. .." and the Encyclopédie méthodique called it "the act of killing oneself to deliver oneself of an ill one hasn't the courage to bear."6 Among enlightened philosophers, some saw suicide as a rational and legitimate personal option. Montesquieu argued that suicide harmed neither society nor God since society is formed on mutual advantage and if a person no longer gains any advantage from that situation they are free to leave it. Voltaire directed his sarcasm to the punishments directed toward the bodies of suicides and their families and rejected the accusation of cowardice because the instinct of self-preservation is so powerful that only a strong person could overcome

\footnotetext{
${ }^{4}$ Howard I. Kushner, Self-Destruction in the Promised Land: A Psychocultural Biology of American Suicide (New Brunswick: Rutgers University Press, 1989): 17-25; Keith Burgess-Jackson, "The Legal Status of Suicide in Early America: A Comparison with the English Experience," Wayne Law Review 29 , no. 57 (1982): 57-87.

${ }^{5}$ Georges Minois, History of Suicide: Voluntary Death in Western Culture (Baltimore: The Johns Hopkins University Press, 1999): 210-212.

${ }^{6}$ Georges Minois, History of Suicide, 214-215.
} 
it. Similarly, David Hume argued that suicide did not offend God because all beings had been given power to change things to insure their well being and God received death by suicide the same as any other death. In addition, suicide was not an offense against oneself because a person would not throw away a life worth keeping. Holbach claimed that suicide was not a cowardly act because the misfortune and the affliction was real for the person feeling it and in that unhappiness the strength was found to overcome the instinctual fear of death. ${ }^{7}$

On the other hand, some philosophers such as Jean Dumas, John Adams, and Jean-Jacques Rousseau condemned suicide as an immoral and cowardly act. For example, Diderot denounced suicide and said that disgust for life only existed in a deranged or poorly organized head. Diderot's comments illuminate a trend that was occurring throughout Europe during the Enlightenment. Despite debate among philosophers about criminalizing or condemning suicide, both sides agreed that the decision to kill oneself was made by the free rational will of an individual. No longer was suicide the result of Satan's work; instead, many philosophers moved towards the idea that suicide resulted from madness. The shift in emphasis put suicide under medical authority instead of civil or religious authority. This helped decriminalize suicide and transform the suicide into a victim of society and individual psychology. Trials for suicide declined over the eighteenth century and Europe saw more efforts of rehabilitation, such as sending suicidal people to asylums, workhouses or prisons to

\footnotetext{
${ }^{7}$ Georges Minois, History of Suicide, 228-230, 232, 250-251, 253-254; Howard Kushner, Self-Destruction in the Promised Land, 28.
} 
prevent second attempts and the creation of humane societies to prevent suicides by drowning. ${ }^{8}$

Howard Kushner argues that these Enlightenment debates did not affect America even though Americans were familiar with these writers. Indeed, suicide remained a crime in Massachusetts until the late-nineteenth century; however, the penalties were invoked less frequently. The Revolution became the occasion for Virginia, New Jersey, Maryland, North Carolina, and Pennsylvania to change their policies, and juries increasingly returned verdicts of insanity for cases of suicide. Perhaps Kushner recognized a delay between the Enlightenment and the time when those ideas truly influenced America, but by the antebellum period suicide was increasingly decriminalized and placed under the jurisdiction of medicine, as it had been in Europe. ${ }^{9}$

Used as an index of their fellow man's moral health, some antebellum Americans became concerned with what they perceived as a suicide epidemic, particularly influenced by the sentimentalization of suicide in popular culture. The suicide rate for the antebellum years is unknown so it is unclear whether there truly was a rise in actual suicides; however, Americans perceived a rise. Newspaper readership boomed in the antebellum years and increased news coverage brought more attention to crime, especially local crimes. To avoid charges of sensationalism, newspapers published the facts of the crime creating a sense of "human derangement and depravity." Novels were also a concern for middle-age fathers who worried that depictions of suicide would encourage their sons and daughters to copy those actions. Critics condemned Goethe's

\footnotetext{
${ }^{8}$ Howard Kushner, Self-Destruction in the Promised Land, 27; Georges Minois, History of Suicide, 236, 241-246, 283, 286, 300-301.

9 Richard James Bell, "Do Not Despair: The Cultural Significance of Suicide in America, 1780-1840" (PhD Dissertation, Harvard University, 2006): 30-31; Georges Minois, History of Suicide, 241-246; Howard Kushner, Self-Destruction in the Promised Land, 28-32.
} 
popular The Sorrow of Young Werther which they claimed condoned and romanticized suicide and suggested that there were times when self-destruction was acceptable.

Sentimental suicide was a key feature in the plots of many such works with depictions of the young man unrequited in love, the seduced and ruined young woman, and the literary villain. The assumptions that death, destruction, and the corpse itself could be fundamentally beautiful in its own right found voice in romanticism and death poetry, among other mediums. An immensely popular exhibition painting by Rembrandt Peale in 1820 focuses the audience's attention on a central grouping of figures including Death, the corpse of a young man, and an old man supported by Faith. Entitled The Court of Death, the depiction of the young man's body is one of sculptured beauty. These central figures are flanked by the "war unit" and the "pleasure unit," representing those forces which so often cause death and destruction. Among those figures representing the moral evils of indulgence and intemperance is the figure of Suicide. Whether or not the rate of suicides was actually increasing may never be known, but Americans encountered suicide more frequently in their novels, newspapers, and material culture. ${ }^{10}$

As Richard Bell argues, in post-Revolution America self-destruction drove public conversation in many forms because at this time Americans felt a high level of concern about suicide. Even though suicide was largely vilified, most people knew someone who had attempted or committed suicide which gave the subject "cultural currency" in many public debates. Americans interpreted suicide as a selfish act that embodied tensions between individuals and society. With drastic changes occurring in rapid population growth, increasing mobility, and changing economics, certain groups found it in their self

\footnotetext{
${ }^{10}$ Richard James Bell, "Do Not Despair," 3-4, 15-16, 44-45, 54, 65-66, 71-81, 86-88, 93, 95-97; Mark S. Schantz, Awaiting the Heavenly Country: The Civil War and America's Culture of Death (Ithaca: Cornell University Press, 2008): 108, 196-205.
} 
interest to define the boundaries of individual behavior. The behavior of citizens was a political concern, placing suicide at the center of these debates. In the wake of a war for independence self-government had two meanings: free, representative, non-monarchical government based on an informed citizenry and the freedom of individuals to shape their own lives. However, individual interest often went against collective interest and, to some, unregulated individual conduct threatened the foundations of the new Republic. Suicide was a challenge to the Republic's governing ability since it was the most radical expression of selfhood; taking one's life was a flaunting of individualism, a vote of no confidence in the government. ${ }^{11}$

By connecting suicide to the questions of citizenship and government, the act of taking one's life became politicized. Moralists reacted to the perceived epidemic by printing condemnations of the behaviors they believed led to suicide, including deism, disappointed pride, selfishness, short-sightedness, immorality, cruelty, cowardice and lunacy. Ministers used their pulpits to speak out against self-murder and activist movements against gambling, dueling, and drinking used suicide as a comparison to demonize those vices. ${ }^{12}$ These risk-taking behaviors were perceived as destructive to individual and national character due to the abandonment of civil law and industry. Gambling and its financial consequences often led to ruin and suicide, dueling was a double sin of murder and suicide, and long-term drinking was akin to a disease that

\footnotetext{
${ }^{11}$ Richard James Bell, "Do Not Despair,” 3-4, 18, 23-25, 454-456.

${ }^{12}$ Interestingly, the Bible does not say much against suicide. Certain scriptures have been used to support a negative view of slavery-Exodus 20:13, Ecclesiastes 7:17, and 1 Corinthians 6:19-20 are commonly used - however, none of them are in reference to suicide. In addition, there are seven suicide stories in the Bible (Abimelech in Judges 9:52-54, Samson in Judges 16:25-30, Saul and Saul's armourbearer in 1 Samuel 31:4-5, Ahithophel in 2 Samuel 17:23, Zimri in 1 Kings 16:15-20, and Judas in Matthew 27: 3-5); despite an occasional comment about the sin or wickedness of the person in terms of his actions in life, commentary on their mode of death is absent. This analysis is based on reading the King James Version, which was widely used by protestant denominations, and the Douay Version popular with Catholics (based on email communication between the author and George C. Rable, January 18, 2012).
} 
slowly destroyed the body. The anti-gallows movement also used the language of suicide in their arguments against the death penalty. The suicides of prisoners, especially those who were to be executed, cheated the public out of punishing a criminal and undermined the justice system. The anti-gallows movement argued that society had no right to execute its members because under a social contract the individual must surrender that right to the greater good; however, no person had given society the right to end their life. Charles Spear wrote in "The Suicide of a Murderess" in 1845, "If man has no right to kill himself, how can he justly convey that right to another man, or to any body of men." Especially important in the origins of the Civil War, the abolitionists adopted slave suicides as central images in their portrayal of slavery. Depicted as killing themselves to escape excessive punishments, transportation and separation from families, or forced return to slavery, suicide was an acceptable last resort for slaves. These descriptions were meant to outrage readers: the effects of slavery were so bad that suicide- "usually understood as the most morally reprehensible act"—was morally justifiable and heroic. Slave and inmate suicides changed American responses to suicide, but, despite a measure of compassion toward those desperate enough to take their lives, unambiguous opposition led by cultural conservatives remained against suicide. ${ }^{13}$

In addition to shifts in the criminalization, sentimentalization, and politicization of suicide, the antebellum years also witnessed the medicalization of suicide. First in Europe during the Enlightenment and then in America during the antebellum years, suicide became a question of medicine and the focus turned to resuscitating and reforming suicide victims. This was evidenced first by the increasing frequency of

\footnotetext{
${ }^{13}$ Richard James Bell, “Do Not Despair," 99-103, 186-215, 238, 242 (quote), 256, 264, 277, 296, 312, 376, 379-404, 419-420, 435-440, 460.
} 
insanity rulings by coroners' juries in cases of suicide or rulings of "accident" or "misadventure." Previously used in Europe, humane societies were formed in America to prevent suicide by drowning. These societies rewarded people who risked their own lives to rescue others and paid physicians to resuscitate suicide victims, even those who fought against the intervention. These efforts encouraged everyone to be alert to possible suicide attempts. Suicide prevention programs blended the sacred and secular; suicide was still considered a sin by many people so rescuing a suicide victim saved them from both death and eternal damnation. Resuscitation was not enough however; reform became the new focus in the antebellum age. In the early nineteenth century the movement shifted to building asylums to care for the insane, including the suicidally insane, another step of society exerting its control over citizens who would exercise their right to die. ${ }^{14}$

Nineteenth century doctors sought new answers in suicide and mental illness. Originally they believed that any imbalance in a person's physical system could affect the nervous system or blood, producing a symptom of melancholy that if untreated could worsen to insanity. To treat these patients doctors focused on keeping the body balanced using emetics, cathartics, diuretics, and bleeding. By the 1830s, these extreme treatments were tempered with the use of stimulants and sedatives. Contributing to changing attitudes, the popularity of phrenology added to the idea that madness could be a mental disorder. Phrenology, in which a person's characteristics could be read by the features of their skull, argued that environment and behavior could affect specific locations of the brain. Facing rapid changes in the Industrial Revolution, some critics blamed the

\footnotetext{
${ }^{14}$ Richard James Bell, “Do Not Despair,” 33-34, 42, 126-127, 160, 164, 166-170, 183-184; Howard Kushner, Self-Destruction in the Promised Land, 32.
} 
environments of cities for the rising suicide rate. The aspirations nurtured by new opportunities, access to leisure time, the temptations of drugs and alcohol, and the workings of the business world combined with new independence for individuals, economic fluctuations, and poverty in the working class created people who were more likely to commit suicide than their rural counterparts. In this context individuals were malleable and could be changed and influenced. A few doctors argued that sane suicides were possible, but the main focus remained on connecting suicidal insanity with environmental causes. In a negative sense this could produce more suicide victims; however, this also led to the belief that patients could be reformed back into productive citizens, causing asylums to shift away from their previous, more brutal tactics. This change also reflected progressive and humanitarian trends in nineteenth century society. This medicalization of suicide also coincided with the growth of institutional psychiatry as evidenced by the 1844 organization of the Association of Medical Superintendents of American Institutions for the Insane (AMSAII). The members of the AMSAII were not necessarily psychiatrists, but the organization evolved into the American Psychiatric Association of the twentieth-century. While medicalization meant that suicides were treated as victims instead of criminals and increased the clemency and compassion directed towards those contemplating or committing the act, cultural conservatives continued to place suicide among the "shameful illnesses," moving repression of suicide inward to the individual conscience and making it a taboo subject. ${ }^{15}$

\footnotetext{
${ }^{15}$ Georges Minois, History of Suicide, 315, 318-321; Howard Kushner, Self-Destruction in the Promised Land, 34, 37-40, 42, 44-45; Richard James Bell, "Do Not Despair," 459-460.
} 


\section{The Experience of Combat}

Given an atmosphere in which suicide was frequently included in popular culture and public discourse, and in which there was a growing fear of a suicide epidemic, it seems likely that Civil War soldiers and their families were aware of it. For soldiers, leaving home and entering a world far different from civilian life, change would come rapidly and without mercy. Soldiers went through a psychological evolution from civilian to volunteer to soldier as they coped with the challenges of war, each step changing them more and taking them further from their civilian lives. This process included suppressing pre-war identities and creating new ones, identities based on professionalism and a certain amount of callousness in order to survive the war. The gateway to this process was what Gerald Linderman called a "simmering down" that manifested itself in several forms. As volunteers entered into the service they discarded unnecessary equipment and non-essential items to make their gear as light as possible on the long marches. In addition, the first casualties of most regiments were from disease, a "simmering down" process that thinned out the ranks. Initially, soldiers welcomed this process for they saw it as ridding the army of the weak and the cowards: New Yorker George Newcomb noted in 1862, "Eney [sic] new Regt has to go through the culling process before it will become a good and efficient Regt." As the process continued, however, and even the bravest men died, soldiers felt their own vulnerability. ${ }^{16}$

In addition, these men faced what Eric Dean called "a destroying manner of living." Soldiers primarily marched from place to place, sometimes ten or more miles a

\footnotetext{
${ }^{16}$ Gerald F. Linderman, Embattled Courage, 113-116, 245-247; Reid Mitchell, Civil War Soldiers: Their Expectations and Their Experiences (New York: Viking Penguin Inc., 1988): 56-57; Earl J. Hess, The Union Soldier in Battle: Enduring The Ordeal of Combat (Lawrence, KS: The University Press of Kansas, 1997): 157, 185; Mark H. Dunkleman, Brothers One and All: Esprit de Corps in a Civil War Regiment (Baton Rouge: Louisiana State University Press, 2004): 115 (quote).
} 
day, with few or no breaks, often for many days in a row. Impending battle created the necessity for forced marches, with increased length and speed and no room for exhaustion. The elements were another factor as soldiers were often exposed to the weather without enough protection while on the march or being transported, in camp, and in battle. ${ }^{17}$ O.W. Norton complained of one night when the rain "commenced to pour down, and the water ran through our tent, round it, and under it, and we just had to lie in a puddle of it all night ... scarcely a dry spot in the tent." ${ }^{, 18}$ Clothing and tents were sometimes in short supply or bad condition, and at times fires were forbidden for fear the enemy would spot them, depriving soldiers of warmth and hot food. Fighting near Winchester in 1863, Charles Lynch wrote in his diary for June 13: "The night was a very dark, stormy one, with severe lighting and thunder. We were wet through. Not allowed fires as it might draw the enemy's fire. Passed an uncomfortable night."19 The presence of a fire did not necessarily mean comfort, however, as evidenced by a October 1862 diary entry by Cyrus F. Boyd who complained, "Had no blankets with us and we suffered much last night in the cold rain[.] We could not sleep and had to stand up about all night around a little fire which we tried to keep alive." ${ }^{20}$ Charles Wright Wills also complained of the soaking rain and the cold turning his fingers blue, but the consolation was that it stopped the chiggers from biting. Conditions in camp led to uncleanliness and insect infestations, a humiliation for men accustomed to better circumstances. In addition to the chiggers, the "ants also have an affinity for human flesh and are continually

\footnotetext{
${ }^{17}$ Reid Mitchell, Civil War Soldiers, 59-60; Eric T. Dean, Jr., Shook Over Hell: Post-Traumatic Stress, Vietnam, and The Civil War (Cambridge, MA: Harvard University Press, 1997): 46-50.

${ }^{18}$ O.W. Norton to "Sister L," April 21, 1862. SoldierStudies.org, accessed November 12, 2011.

${ }^{19}$ Charles H. Lynch, diary, June 13, 1863. SoldierStudies.org, accessed November 29, 2011.

${ }^{20}$ Mildred Throne, ed. The Civil War Diary of Cyrus F. Boyd, Fifteenth Iowa Infantry, 1861-1863 (Baton Rouge: Louisiana State University Press, 1953): 78.
} 
reconnoitering us," wrote Wills, "I kill about 200,000 per day. Also, knock some 600 worms off of me ... I pick enough etomological specimens off me every day to start a museum." 21 These conditions facilitated the spread and ravages of disease.

Men adapted to their changed lives at different rates, some defining themselves as soldiers quickly, others becoming frightened by the changes they saw in themselves. Men transgressed against their normal behavior and the wishes of family members as the dull experiences of camp life and long winter encampments led some to try many of the vices and entertainments they had staunchly opposed at the beginning of the war. In battle, soldiers welcomed the hardening that allowed them to withstand horrific experiences, but there came a point when they no longer seemed to care about human life. "We passed around, among the dead bodies and wounded soldiers," said Henry C. Lyon of the $34^{\text {th }}$ New York, "apparently no more affected than would we be if we saw a number of Dead Beavers. ${ }^{, 22}$ When writing about artillery fire, O.W. Norton was glad there were no women around for "[e]very time a shell exploded they would jump and think "there goes death and misery to some poor fellow." He and his fellow soldiers no longer thought that way for "we have grown so careless and hardened that we don't heed them." 23 Death was ever-present in the lives of Civil War soldiers and they became indifferent to it, sometimes to the point at which they could function normally, joke, and enjoy pranks in battle or even live among the dead on the battlefield. ${ }^{24}$ "The scenes of blood and strife that I have been called to pass through during the months that are passed,

\footnotetext{
${ }^{21}$ Charles Wright Wills, entry for June 13, 1864. SoldierStudies.org, accessed November 14, 2011; Reid Mitchell, Civil War Soldiers, 59-60; Eric T. Dean, Jr., Shook Over Hell, 51-52.

${ }^{22}$ Mark S. Schantz, Awaiting the Heavenly Country, 106.

${ }^{23}$ O.W. Norton to "Sister L," April 21, 1862. SoldierStudies.org, accessed November 12, 2011.

${ }^{24}$ Earl J. Hess, The Union Soldier in Battle, 82, 146-149; Reid Mitchell, Civil War Soldiers, 69-74; Gerald

F. Linderman, Embattled Courage, 118-123, 241-243; Eric T. Dean, Jr., Shook Over Hell, 211.
} 
and my "baptism in blood," admitted infantryman Warren Freeman, "have nearly destroyed all the finer feelings of my nature." 25

The experience of battle was a major change for most of these new soldiers. Green recruits wanted to get into the fight quickly, worried that the war would end before they saw combat. Stimulated by desires to prove their honor and manhood, new soldiers wanted to experience their first battle in order to prove themselves. Their eagerness would soon change as they experienced the worst anxiety before battle, as they moved into the vicinity of combat. Seeing the wounded streaming to the rear, the refuse of war strewn on the ground, and hearing the sounds of combat while not being personally engaged was tough on men preparing themselves for battle. "It is worse for a soldier to wait for a battle to begin than it is to do the fighting," admitted one man. Artillery bombardments were especially intense for waiting soldiers. "Nothing is more trying to the nerves," wrote infantryman William P. Lyon, "than ... to have to remain silent and motionless under a fire which they are not permitted to return. ${ }^{26}$ The explosion of shells was great and visible to the men, and they could not move or react in any way. An ideal expression of courage was to receive such fire without moving, but many soldiers instinctively ducked at each shell. ${ }^{27}$

Once they entered into the surreal world of combat soldiers stepped into an environment of chaos and disorder. The smoke, terrain, and confusion made it difficult for them to see the enemy, or even where they were going, and, in some cases, made it

\footnotetext{
${ }^{25}$ Warren H. Freeman to father, October 3, 1862. SoldierStudies.org, accessed November 29, 2011. ${ }^{26}$ William P. Lyon to the Racine Advocate, May 10, 1862. SoldierStudies.org, accessed November 12, 2011.

${ }^{27}$ Gerald F. Linderman, Embattled Courage, 21; Eric T. Dean, Jr., Shook Over Hell, 43, 53-54, 63-64; James M. McPherson, For Cause and Comrades: Why Men Fought in the Civil War (New York: Oxford University Press, 1997): 31, 38.
} 
difficult to maintain battle lines and command structure. Coming under fire, especially if a near-miss was experienced, could feel almost unreal. Soldiers were amazed that they could come out of such an environment unscathed, sometimes with bullets having passed so close to have left holes in clothing or equipment. Sounds assaulted their ears, the varying sounds of shot and shell and the sounds of their comrades yelling or dying. Deaths on the battlefield were shocking and disillusioning to many soldiers. Civil War era men were used to death as it occurred in the civilian world: comprehendible, neat, orderly, respectful and surrounded by ceremony and family. The deaths they now witnessed were the opposite: chaotic, random, sudden, and gruesome. ${ }^{28}$

The impact of battlefield fatality could be particularly severe when soldiers witnessed the close range deaths of family members, friends, or close comrades. ${ }^{29}$ Austin Carr of the $82^{\text {nd }}$ New York went to war with a friend from home, and their friendship continued through their military service. Fred was standing in front of Austin in battle when a bullet ripped through his side and bowels, a wound that Austin knew was fatal. Austin leaned over his friend and heard his last words, but had to leave him behind. Expressing a sense of brokenness and anguish at the thought of his friend lying ruined on the battlefield, Austin volunteered for burial duty the next morning in the hope of finding Fred's body. Unlike so many, he was fortunate enough to locate the remains: "And then - there he was - lying so still, my buddy, Fred, He had given all that was possible for a man to give, somehow I felt bitter in my heart against this thing called war." Fred was lucky enough to be buried by a friend in an individual grave on the side of the hill away from the others, unlike most soldiers during the war. Austin would never forget the

\footnotetext{
${ }^{28}$ Earl J. Hess, The Union Soldier in Battle, 9-19, 24-25, 28-29, 38, 47-63; Eric T. Dean, Jr., Shook Over Hell, 57, 63-64, 73-74; Gerald F. Linderman, Embattled Courage, 124-127.

${ }^{29}$ Eric T. Dean, Jr., Shook Over Hell, 73-74.
} 
death of his friend: "I could scarcely bring myself to look upon his crude grave," he wrote, "tears gushed down my face in spite of all my efforts to stop them, and so I bid him goodbye and left him there to sleep. The bitter wound in my heart to last forever." ${ }^{30}$

Many soldiers reported feeling no fear in the midst of battle - the anxiety disappeared and they were able to focus on their tasks, ignoring danger, bodily needs, and the passage of time. While dreading battle as it approached, a New Hampshire private stated that "it isn't long before you won't think or care whether you are in it or not ... for a man in the heat of battle thinks nor cares for nothing but to make the enemy run." As James McPherson points out, this was probably due to a rush of adrenalin produced from the high level of stress resulting from battle. Those men who overcame the initial "flight" reaction, turned into fighting machines so committed to battle that their actions have been labeled combat frenzy, fighting madness, or battle rage. Civil War soldiers did not know about the body's chemical reactions to stress or about adrenaline, but they did recognize when men were "fighting crazy" or performing almost inhuman feats on the battlefield. In the fighting around Petersburg, William Phillips was astonished by his response to battle: "My eyes saw it all, in red and flame, but I could not digest it somehow." Rushing forward, led by "some other power than myself" he ran straight into the Confederate works. ${ }^{31}$ This "combat narcosis" definitely assisted soldiers in battle, making them almost numb to the events around them, even though they were still witnessing and experiencing them. "During that terrible 4 or 5 hours that we were there I had not a thought of fear or anything like fear," wrote a Massachusetts lieutenant about

\footnotetext{
${ }^{30}$ Austin Carr diary (excerpted transcript). Army Heritage and Education Center, Carlisle, PA. The Harrisburg Civil War Round Table Collection, Box 7. The entries in this transcript are undated, so I could not determine which battle Fred died in.

${ }^{31}$ William Beynon Phillips to Annie, July 4, 1864. SoldierStudies.org, accessed November 11, 2011.
} 
Malvern Hill, "on the contrary I wanted to rush them hand to hand." He had been dreading the battle the entire day before, he admitted, "yet it seemed as the moment came all fear and all excitement passed away and I cared no more than I would in a common hail storm." Once soldiers were on the field of battle they relied on the absence of fear and the simplification of battle to a "common hail storm" to do their job. ${ }^{32}$

The absence of fear in battle helped men fight, but it also heightened the reality of the aftermath when they began to inspect the battlefield. The debris of war was scattered over the ground, which itself bore the marks of battle, but the worst sight was the dead and wounded men. There was no time to give each casualty the attention usually given to the dead in civilian life; instead, remains were buried hastily, sometimes in mass graves, or neglected completely. Remains left uncovered for days before burial crews could reach them were almost unrecognizable as men; soldiers detailed to burial duty had to deal with these scenes in addition to the experience of battle. Men described being unnerved and sickened by the sights seen after battle, wishing they would never have to see them again. Some retained mental images of certain deaths that they could not forget. The trauma of these experiences came at a vulnerable time for soldiers, when they were feeling the physical and psychological collapse after the rush of battle. A man's supply of adrenalin is not unlimited; the end of a battle, or even a lull or retreat in the midst of battle, could cause severe reactions as the body tried to restore its chemical balance. The physical and mental impact of what they had just done finally set in; they realized how tired, dirty, sore, and thirsty they were and could feel depression, low morale, and sudden vulnerability. Surveying the damage and feeling physically affected by battle, the fears

\footnotetext{
${ }^{32}$ James M. McPherson, For Cause and Comrades, 39-42 (quote); Eric T. Dean, Jr., Shook Over Hell, 5457.
} 
men had pushed aside in the heat of battle returned even more intensely than before. Men who witnessed battlefield casualties, the treatment of remains, and the very real possibility of an anonymous death felt the inevitability of their own demise, and the fear of the time they too would become a casualty. The impact of a battle could linger for weeks, months, or years as bodies and evidence of combat remained visible to soldiers marching through or camping on old battlefields. Even more personal, names absent at daily roll call were a constant reminder of the losses they had suffered, and those they might suffer in the future. ${ }^{33}$

\section{Mental Stress in the Union Army}

Not every soldier committed suicide or had suicidal thoughts, but most experienced at least a degree of mental trauma. Suicide was an extreme action, but soldiers only reached that point by building off of smaller stressors. The conditions and new experiences of the war were unsettling to the volunteer soldier, and they had to deal with them mentally as well as physically. Some men adapted to the war better than others, but all were affected by what they saw, did, and felt. As Argentinean writer José Narosky said, "In war, there are no unwounded soldiers." Becoming callous to the death and destruction of battle did not mean that soldiers were impervious to its effects. Men had to overcome and reverse their cultural understandings of killing other men to be effective soldiers; for many men it was easier to die than to kill. Men feared dehumanization; feeling like machines could help them withstand battle, but feeling desensitized or disposable was not comfortable. Soldiers came to realize that there were limits to courage, including the fact that it would not protect them from harm. Men

\footnotetext{
${ }^{33}$ Gerald F. Linderman, Embattled Courage, 247-248; Eric T. Dean, Jr., Shook Over Hell, 66-68, 74-75; Earl J. Hess, The Union Soldier in Battle, 29, 37-39, 40-43; James M. McPherson, For Cause and Comrades, 42-43.
} 
realized their own vulnerability and knew their chances of wounds, death, and survival. This acceptance of war's reality could turn a soldier bitter and hopeless, leading some to varying degrees of depression. Soldiers could concentrate on their task during battle, taking advantage of the "hardening" process, but they still witnessed horrible things and reacted to them. ${ }^{34}$

A soldier's own words often betrayed the fact that his experiences affected him even after "hardening" and having time to acclimate to combat and soldier life. Without an official diagnosis or complete understanding of trauma soldiers used terms such as "the blues," "lonesome," "disheartened," "downhearted," "discouraged," "demoralized," “nervous," "played out," "used up," “anxious," “worn down," "worn out," "depressed," "rattled," "dispirited," "sad," "melancholy," and "badly blown" to describe what they were feeling, stemming from a variety of causes. For example, "the blues" could result from the boredom of camp, disease, separation from home, inclement weather and sometimes battle. Cavalryman Henry C. Meyer referred to feeling blue several times in his memoirs; after the Second Battle of Manassas he stated "We all felt rather blue over the loss of comrades in the affair the night before, which had seemed to us so needless," and after an engagement at Aldie he said, "That night was rather a blue time for us." "Demoralized" and "rattled" were most often used when describing the mental collapse of an individual or group while "badly blown" referred primarily to physical collapse with occasional references to mental issues. ${ }^{35}$

\footnotetext{
${ }^{34}$ Drew Gilpin Faust, This Republic of Suffering: Death and the American Civil War (New York: Alfred A. Knopf, 2008): 6, 33-41; Eric T. Dean, Jr., Shook Over Hell, 57; Earl J. Hess, The Union Soldier in Battle, 82-87, 149-153, 156; Gerald F. Linderman, Embattled Courage, 158-159, 245-248; Reid Mitchell, Civil War Soldiers, 58-59.

${ }^{35}$ Eric T. Dean, Jr., Shook Over Hell, 115-116; Henry C. Meyer, Experiences with the New York Cavalry: Under Bayard, Gregg, Kilpatrick, Custer, Raulston \& Newberry 1862-1864 (Oakpost Ltd, 2010): 19, 34.
} 
Despite the murky definitions given by the language used by soldiers, Eric Dean has argued that many of these soldiers suffered from Post-Traumatic Stress Disorder. According to Dean, PTSD, while given that name only after Vietnam, was seen in earlier wars under different definitions, such as "nostalgia," "combat fatigue," and "shell shock." Though using modern terms and definitions in the context of the Civil War may be anachronistic, Dean demonstrates the existence of mental trauma in Civil War soldiers. One example is the case of John Bumgardner of the $26^{\text {th }}$ Indiana Light Artillery, who was knocked down by the concussion of an exploding shell. Recovering himself he was shaken and pale and became morose and sullen for several weeks, in addition to suffering fits of trembling. He would talk about fighting and yell about the enemy approaching when there was no combat present; he was finally sent to an insane asylum in Kentucky. ${ }^{36}$

In some cases, connections to specific symptoms associated with Post-Traumatic Stress Disorder are evident in cases of Civil War soldiers; for example, one symptom of PTSD is reexperiencing trauma through instances of flashbacks or nightmares. James O. Churchill wrote that he would be haunted by a recurring nightmare about his Civil War service: "I would be in battle and charge to the mouth of a cannon, when it would fire and I would be blown to pieces." The case of Albert Frank, fighting around Bermuda Hundred near Richmond, VA, is more severe. While offering the man next to him a drink from the canteen around his neck, the other soldier was decapitated by a shell. That night Frank began to act strangely, running over the breastworks toward the enemy where his fellow soldiers found him huddled, and making shell sounds followed by saying

\footnotetext{
${ }^{36}$ Eric T. Dean, Jr., Shook Over Hell, 7-15, 26-27, 29-30, 66, 70-73.
} 
"Frank is killed." His comrades had to restrain him and eventually sent him to a hospital in Washington under a declaration of insanity. ${ }^{37}$

It did not help that Civil War doctors did not have a good understanding of mental stress and trauma. The Union army recognized insanity as grounds for discharge or exclusion; however, there were no exact guidelines to inform these decisions because more exact diagnoses of insanity would not come until the late nineteenth century. They were, however, becoming aware of the concept of Post-Traumatic Stress Disorder. Prior to the war doctors noticed that victims of railroad accidents experienced "nervous shock" and "hysteria," fear of the place of the accident, sleeplessness, mental depression, loss of energy, stuttering, loss of sexual desire, contraction of the visual field and sleep disturbances, a condition they labeled "railway spine." With the rise of "scientific medicine" in the nineteenth century, moving away from pragmatic or religious explanations, doctors struggled to find the physical changes in the nervous system that would explain these symptoms and be consistent with exact scientific principles. With more study and changes in the theory of treating the mentally ill, the idea began to emerge that the brain was the seat of mental illness and that the symptoms of "railway spine" might be psychological. ${ }^{38}$

These theories did not all translate to the Civil War military in which policies focused on maintaining manpower in the field. Many officials were convinced that any man seeking medical attention or discharge due to a mental or physical disability was a shirker who should be returned to duty. Likewise, doctors saw it as their duty to return shirkers to their units and were on the lookout for feigned insanity in the men seeking

\footnotetext{
${ }^{37}$ Eric T. Dean, Jr., Shook Over Hell, 42, 65-66.

${ }^{38}$ Eric T. Dean, Jr., Shook Over Hell, 27-28, 117.
} 
their attention. Those who did exhibit physical signs of mental trauma were treated for the physical symptoms; if the doctor found "nothing wrong" the men were treated like malingerers. In reality, some, if not many, of these cases may have been recognized as psychiatric casualties from a modern view. However, in the conditions of the Civil War it could be very difficult to tell exactly what a patient was suffering from, whether illness, psychological stress, exhaustion, or a combination of factors. ${ }^{39}$

When faced with blatant cases of mental trauma, doctors struggled to define them without an official diagnosis. Picking up on antebellum definitions, they saw suicide as a result of "insanity" rather than a rational mind. Like the soldiers themselves, doctors had to find words to express what they were seeing in patients, creating four major categories: “insanity," "nostalgia," "irritable heart," and "sunstroke." Insanity could mean rejection from military service or, if already a soldier, admittance into a hospital and/or discharge. This category could be exhibited in three ways: "mania" referred to exhibited agitation or anxiety that could not be attributable to a cause such as a physical symptom or fever; "melancholia" defined depressed or lethargic behavior; and "dementia" was reserved for soldiers who demonstrated a mental deterioration or disordered mental process. The second category, "nostalgia" or "homesickness," was primarily a type of mental deterioration in soldiers far away from home, but it occasionally described post-combat conditions as well. "Trotting heart" did not necessarily pertain to combat experiences, but resulted from exhaustion caused by long periods of exertion. The final category, "sunstroke," was employed similarly to the modern use of "combat fatigue" to reference men who broke down in battle. ${ }^{40}$ This language is seen in the reporting of suicides, on

\footnotetext{
${ }^{39}$ Eric T. Dean, Jr., Shook Over Hell, 118-120, 133-134.

${ }^{40}$ Eric T. Dean, Jr., Shook Over Hell, 116-117, 128-131.
} 
both the official and unofficial levels. Language such as "fit of insanity" (Alexander Anderson, $1^{\text {st }}$ Illinois Artillery), “despondent state of mind” (Andrew J. Bailey, $109^{\text {th }}$ Illinois Infantry), "rendered insane by a sunstroke" (Sylvester Carman, $4^{\text {th }}$ New York Heavy Artillery), “delirium” (Thomas Regan, $95^{\text {th }}$ New York Infantry), “temporarily deranged" (Edward Roche, $1^{\text {st }}$ New York Mounted Rifles), and insanity (Howard C. Mosher, $177^{\text {th }}$ New York Infantry, Thomas J. Pryor, $2^{\text {nd }}$ New York Cavalry, and James E. Wallingsford, $125^{\text {th }}$ Illinois Infantry) was often used in describing suicides. ${ }^{41}$

The policy on military discharges was to maximize manpower in the army, even if soldiers exhibited signs of mental stress. Discharges for insanity could be made only for "manifest" conditions and approval had to be obtained by both the soldier's commanding

\footnotetext{
${ }^{41}$ Alexander Anderson: Illinois. Military and Naval Department, Jasper N. Reece, and Isaac Hughes Elliott, Report of the Adjutant General of the State of Illinois, Volume III, Containing Reports for the Years 1861 1866 (Springfield, IL: Phillips Bros, State Printers, 1901. Google Books): 544; Andrew Bailey: Patrick Brumleve, ed., The Letters of James Evans, $109^{\text {th }}$ Illinois Volunteer Infantry Regiment, August 23, 1862 to April 18, 1863 (Union County Historical \& Genealogy Society, 1996): 2; Sylvester Carman: Augustus Cleveland Brown, The Diary of a Line Officer (1906. Accessed February 3, 2011, American Civil War Diaries and Letters): 90; Annual Report of the Adjutant-General of the State of New York, For the Year 1896. Registers of the Third and Fourth Artillery in the War of the Rebellion (Albany and New York: Wynkoop Hallenbeck Crawford Co., State Printers, 1897): 669, http://dmna.state.ny.us/historic/reghist/civil/rosters/Artillery/4thArtCW_Roster.pdf; accessed 11/7/11; Thomas Regan: Annual Report of the Adjutant-General of the State of New York For the Year 1902. Registers of the Ninety-fourth, Ninety-fifth, Ninety-sixth, Ninety-seventh, Ninety-eighth and Ninety-ninth Regiments of Infantry (Albany: J.B. Lyon Company, State Printers, 1902): 439, http://dmna.state.ny.us/historic/reghist/civil/rosters/Infantry/95th_Infantry_CW_Roster.pdf; Edward Roche: Annual Report of the Adjutant-General of the State of New York For the Year 1895. Registers of the First and Second Veteran Cavalry, First and Second Mounted Rifles, in the War of the Rebellion (Albany and New York: Wynkoop Hallenbeck Crawford Co., State Printers, 1896): 765, http://dmna.state.ny.us/historic/reghist/civil/rosters/cavalry/1stMtdRiflesCW_Roster.pdf; Howard Mosher: Annual Report of the Adjutant-General of the State of New York For the Year 1905. Registers of the One Hundred and Sixty-Eighth, One Hundred and Sixty-Ninth, One Hundred and Seventieth, One Hundred and Seventy-First, One Hundred and Seventy-Second, One Hundred and Seventy-Third, One Hundred and Seventy-Fourth, One Hundred and Seventy-Fifth, One Hundred and Seventy-Sixth and One Hundred and Seventy-Seventh Regiments of Infantry (Albany: Brandow Legislative Printers, 1906): 1153, http://dmna.state.ny.us/historic/reghist/civil/rosters/Infantry/177th_Infantry_CW_Roster.pdf; Thomas J. Pryor: Annual Report of the Adjutant-General of the State of New York For the Year 1893, Volume II. Registers of the $1^{\text {st }}, 2 d, 3 d$ and $4^{\text {th }}$ Regiment of Cavalry, N.Y. Vols. in War of the Rebellion (Albany: James B. Lyon, State Printer, 1894): 599, http://dmna.state.ny.us/historic/reghist/civil/rosters/cavalry/2ndCavCW_Roster.pdf; James E. Wallingsford: Illinois. Military and Naval Department, Jasper N. Reece, and Isaac Hughes Elliott, Report of the Adjutant General of the State of Illinois, Volume VI. Containing Reports for the Years 1861-1866 (Springfield: Journal Company, Printers and Binders, 1900. GoogleBooks): 457.
} 
officer and unit medical officer. However, by 1863 a medical officer in the field could not discharge a man on the basis of insanity; instead, these men went to the Government Hospital for the Insane in Washington, DC where they could be observed by experts. Only about 1,231 men were treated at the Government Hospital for the Insane; the records available for these cases show soldiers who had broken down in battle, gone berserk, or deserted. Most soldiers facing mental stress never made it to Washington. In addition, soldiers suffering from "manifest" insanity and other severe disabilities were not eligible for the Invalid Corps (later renamed the Veteran Reserve Corps), which took men who could no longer fight on the front lines and gave them other duties, such as guard duty, garrison duty, and hospital positions. Instead, some were treated in the field or sent to asylums throughout the states. They were sent from both camp and battlefield for causes ranging from exposure, fear before battle, war excitement, "shock of battle," and the explosions of shells to "fatigue," "sunstroke," and "overexertion." In some cases, if comrades noticed a man who was unable to perform his duties they kept the afflicted in camp, gave him lighter duties, and excused him from combat. Soldiers sometimes took their removal from combat into their own hands, straggling behind, helping a wounded comrade to the rear, or resorting to the more extreme actions of mutiny or self-mutilation. Desertion was another way some men may have sought to remove themselves from the army once they realized they could no longer manage the mental stress; deserters often flew under the radar or remained quiet about their reasons for leaving, but some cases show that mental issues could have been a cause of some desertions. ${ }^{42}$

\footnotetext{
${ }^{42}$ Eric T. Dean, Jr., Shook Over Hell, 118-119, 121, 123-128, 133-134; Earl J. Hess, The Union Soldier in Battle, 85-90.
} 
The most severe expression of mental stress for Civil War soldiers, and the subject to this study, was to kill oneself. Suicide was the ultimate rejection of one's world. The heightened awareness of suicide created in the antebellum age compiled with the intense and dangerous changes experienced in entering the role of a soldier suggests that the Civil War should have seen a substantial number of suicides. That was not the case, however. Suicides were a very small percentage of Union casualties in the Civil War. We will examine a sample of suicides from the Union army based on both contextual and statistical analysis to attempt an understanding of their actions within their environment and experience. 


\section{Chapter 2}

\section{“To Be or Not To Be":}

\section{Suicide Among Union Soldiers}

Far from the feared "suicide epidemic" of the antebellum age, the suicide rate was very low in the Union army. My research has identified 101 soldiers from five Union states who committed suicide within the war years (Figure A), defined as 1861-1866 since some enlistments extended that long. ${ }^{1}$ In total, statistician Thomas F. Barr identified 391 suicides among Union casualties; this means roughly a quarter of identified suicides are addressed in this research. ${ }^{2} 391$ suicides represents less than one percent of the Union casualties during the Civil War, far different than the modern military where suicide has at times been the second leading cause of death for service members. ${ }^{3}$ Why

\footnotetext{
${ }^{1}$ For the most part I found cases of suicide through searching state adjutant reports; these reports were published primarily after the war and contain a listing of the soldiers in each regiment of that state with information such as enlistment, age, residence, promotions, details of service, and death or discharge records. I ended up looking at five Union states-New York, Illinois, California, Connecticut, and Massachusetts - because these were searchable using online resources. When I began I was sure that officials would not want to openly report suicides, but I was surprised to find many comments of "committed suicide" or "killed himself" in the reports along with others using the language of "selfinfliction." In addition, there were others that held more detail: "shot himself," "hung himself," or "downed himself." These are the cases that I have built my research around. Of course, I cannot say that I have found every case of suicide in these five states. Some were not reported as suicides, listed only as deaths, accidents, or drownings, and so would not appear in the searches I did of the adjutant reports. In some cases the adjutant reports listed a soldier's death one way and other sources provided a different story, such as Henry Johnson who's adjutant record states that he drowned while a diary entry reports it as a suicide, or James McMahon where the adjutant report lists him as a suicide but a regimental history reports him only as "died." With the cases I found I tried to flesh them out past the simple statement "committed suicide" by using regimental histories, letters and diaries, and secondary sources. Not only did some of these sources contain more details about specific suicides, they assisted in placing the soldier in his environment to understand what might have influenced his decision.

${ }^{2}$ Thomas F. Barr, "Cost and Compensations of the War," in Military Essays and Recollections: papers read before the Commandery of the State of Illinois, Military Order of the Loyal Legion of the United States, Volume I (Chicago: A.C. McClurg and Company, 1891): 521.

${ }^{3}$ Using Barr's statistics, 391 suicides out of his calculated 359,528 total casualties puts the suicides rate for the Union army as $0.108 \%$; Another set of statistics created by Frederick Phisterer counts 302 suicides out of 304,369 total Union dead, a rate of 0.099\% [Frederick Phisterer, Statistical Record of the Armies of the
} 
the rate was so low for Civil War soldiers is an important question to address; however, we will first examine what these suicides can tell us about the experience of the Civil War soldier.

\begin{tabular}{|c|c|}
\hline$\underline{\text { State }}$ & Number of Identified Suicides \\
\hline California & 8 \\
\hline Connecticut & 6 \\
\hline Illinois & 25 \\
\hline Massachusetts & 1 \\
\hline New York & 60 \\
\hline Unknown & 1 \\
\hline
\end{tabular}

Figure A: Suicide Cases By State

Suicide is a difficult topic to explain into patterns and structures. A private, and sometimes sudden, decision, outside observers might not be able to determine what caused the act. As Emile Durkheim stated in his groundbreaking study on suicide, "One would have to know the psychological condition of the suicide at the moment of forming his resolve, how he prepared to accomplish it, how he finally performed it, whether he were agitated or depressed, calm or excited, anxious or irrational, etc."4 This difficulty is aggravated by a distance of 150 years and in most cases it is impossible to pinpoint the exact causes of suicides. However, it is possible to conjecture answers from data and details collected from these cases; these patterns can tell us about the environment in

United States (New York: Charles Scribner's Sons, 1883): 69-70]; Craig J. Bryan, “The Clinical Utility of a Brief Measure of Perceived Burdonsomeness and Twarted Belongingess for the Detection of Suicidal Military Personnel," Journal of Clinical Psychology 67, no. 10 (2011): 981.

${ }^{4}$ Emile Durkheim, Suicide: A Study in Sociology, translated by John A. Spaulding and George Simpson, edited by George Simpson (Glencoe, IL: The Free Press, 1951): 146. 
which the suicides occurred. ${ }^{5}$ In examining the clues given by this sample of suicides, we will look at patterns evident in the data as well as analyzing possible stressors these men faced during the war. The most important variables seem to be soldiers' proximity to traumatic battlefield experience, injuries or hospital stays, and time as prisoners of war. In addition, I found that age was a factor, the age bracket of 26-30 seeing a higher percentage of suicides. Also influential were the time of year, time within campaign, and amount of enlistment completed.

\section{Suicides in the Union Army}

When looking at possible stressors for mental trauma the most evident is battle; battle and violence are essential elements to war. Soldiers found themselves in a violent and disorienting situation far from the lives they were accustomed to living, and this produced a varying range of reactions, such as those already discussed. Beyond the jarring sensation of experiencing battle, a soldier's position on the battlefield may have also influenced their mental state. The vast majority of these suicides were infantrymen, with cavalrymen, artillerymen, and engineers following in that order (Figure B). ${ }^{6}$ This pattern corresponds with the number of men enlisted in each branch of the military, but it also coincides with the frequency and type of combat each branch experienced. Infantrymen were most likely to be the receivers of both artillery and infantry fire, as well as making attacks or defending positions against attack. Cavalrymen were often used as scouts or in raids, mostly small-scale actions, although they could see action in large

\footnotetext{
${ }^{5}$ Because suicide is a very personal decision in which outside observers may not know the full circumstances it is almost impossible to know precisely why these soldiers killed themselves. What I offer here are possible answers to their actions based off the available sources with the admission that they may not be entirely accurate. I have attempted to piece together available details on the cases with context information to present an argument that highlights these stories while examining soldier experience in the Civil War.

${ }^{6}$ Mounted Rifles as included in the cavalry branch in this statement.
} 
battles as well. However, their combat was usually close-quartered more regularly than infantry combat, which may explain why they followed the infantry in number of suicides. Third in rates of suicide, artillerymen witnessed and participated in large- and small-scale battles, but their involvement included distance. They manned the longestrange weapons, they almost never had to participate in a charge upon the enemy, and they faced close-combat only when their lines of infantry support failed. The rate of suicide among engineers is dramatically smaller.

\begin{tabular}{|c|c|}
\hline Military Branch & Number of Identified Suicides \\
\hline Infantry & 61 \\
\hline Cavalry & 25 \\
\hline Artillery & 10 \\
\hline Engineers & 3 \\
\hline Mounted Rifles & 2 \\
\hline
\end{tabular}

Figure B: Suicide Cases by Military Branch

The Battle of Fredericksburg offers an example of the impact of battle on soldiers; it is the only battle in which multiple suicides within this sample are connected. Union regiments faced high losses and trauma, particularly those who participated in the attacks on Marye's Heights. Defeat weighed heavily on these men. Benjamin Hirst of the $14^{\text {th }}$ Connecticut Infantry, wrote about the complete failure of their attacks in his journal. " $[\mathrm{I}] \mathrm{t}$ was the first time the Rebels had ever seen the Backs of the second Army Corps," he wrote, "and I pray it may be the last one." When writing to his wife Sarah about the severe losses of his regiment, he told her she must consult the newspapers, "as I cannot write at this time." Later he reported to her that his company lost fourteen men out of 
twenty-five. $^{7}$ At least two soldiers are identified as having committed suicide on December 13, 1862 at Fredericksburg. Forty-two year old James Fox witnessed his first engagement with the $32^{\text {nd }}$ New York Infantry at Fredericksburg; they held the center of the Union line, between the two main areas of action. Despite their relative inactivity, they could hear the firing of the fight around them; perhaps this produced anxiety that led James to shoot himself. ${ }^{8}$ It is unknown who the other Fredericksburg suicide was, but we do know that it was a second person because this man shot himself on Marye's Heights, a different portion of the field. ${ }^{9}$ Fredericksburg stood out to soldiers as a particularly traumatic event. Besides the humiliation of defeat and retreat, this battle saw some of the most unequal losses of the war. The Confederate army lost just over 5,000 casualties compared to the Union's 12,500 casualties. Fredericksburg remained in the memories of soldiers who had fought there because of the sheer sense of slaughter that resulted from these casualties, the helplessness of soldiers unable to touch their well-concealed enemy, and the resulting sense of failure.

After the defeat of Fredericksburg, these men faced more disaster in the "Mud March," another attempt by General Ambrose Burnside to attack General Robert E. Lee's Confederates that became mired in a storm. The $14^{\text {th }}$ Connecticut was the rear guard for this march so they had not even left camp when the column became stuck. As a result of the double failure of Fredericksburg and the Mud March morale was very low in the

\footnotetext{
${ }^{7}$ Robert L. Bee, ed., The Boys From Rockville: Civil War Narratives of Sgt. Benjamin Hirst, Company D, $14^{\text {th }}$ Connecticut Volunteers (Knoxville: The University of Tennessee Press, 1998): 68-70, 76.

${ }^{8}$ Annual Report of the Adjutant-General of the State of New York For the Year 1899. Registers of the Twenty-sixth, Twenty-seventh, Twenty-eighth, Twenty-ninth, Thirtieth, Thirty-first and Thirty-second Regiments of Infantry (Albany: James B. Lyon, State Printer, 1900): 925, http://dmna.state.ny.us/historic/reghist/civil/rosters/Infantry/32nd_Infantry_CW_Roster.pdf; Hance Morgan diary. Army Heritage and Education Center, Carlisle, PA. Civil War Times Illustrated Collection, Box 17. ${ }^{9}$ Thomas H. Evans, "The Cries of the Wounded were Piercing and Horrible," 33; George C Rable, "It Is Well That War Is So Terrible," 58.
} 
winter of 1862-1863. A reduced strength of less than one third their original size and a large amount of picket and guard duty intensified the low spirits. These stressors may have been too much for one member of Benjamin Hirst's company; Adam Woldert committed suicide on February 3, $1863 .^{10}$ Another soldier, cavalryman Jason Reed, did not make it to February. Despite being minimally engaged in the battle, he committed suicide near Belle Plain exactly one month after the Battle of Fredericksburg. ${ }^{11}$

The Battle of Fredericksburg drew the curtain on 1862, the second year of the war and the year suicide numbers rose dramatically (Figure C). There are several reasons 1862 might have been marked by higher suicide numbers than the first year of the war. First, the idea that the war would be a quick contest was destroyed at this point; the first battle at Manassas proved that the war would not be short and as 1862 dragged on there was no end in sight. Coupled with that, soldiers enlisted for longer periods of time, adding to the sense that the war would be a drawn-out struggle. Longer enlistments and longer war meant longer time away from home and family, putting stress on relationships and support systems crucial to soldiers. In addition, warfare was escalating in 1862 . The first engagements in 1861 shocked a nation not used to such casualty rates; engagements at Antietam, Shiloh, the Virginia Peninsula, and Fredericksburg made it clear that it would grow much worse.

\footnotetext{
${ }^{10}$ Record of Service of Connecticut men in the army and navy of the United States during the War of Rebellion (Hartford, CT: Press of the Case, Lockwood \& Brainard Co., 1889. Ancestry.com): 566; Robert L. Bee, ed., The Boys From Rockville, 68-70, 76.

${ }^{11}$ Annual Report of the Adjutant-General of the State of New York For the Year 1894. Volume III. Registers of the $9^{\text {th }}, 10^{\text {th }}, 11^{\text {th }}$ and $12^{\text {th }}$ Regiments of Cavalry, N. Y. Vols., in the War of the Rebellion (Albany: James B. Lyon, State Printer, 1895): 579, http://dmna.state.ny.us/historic/reghist/civil/rosters/cavalry/10thCavCW_Roster.pdf; Burton B. Porter, One of the People: His Own Story (Burton B. Porter, 1907): 121-122; N.D. Preston, History of the Tenth Regiment of Cavalry, New York State Volunteers, August, 1861, to August, 1865. (New York: D. Appleton and Company, 1892): 56-58, US Army Heritage and Education Center, Carlisle, PA.
} 


\section{Suicides By Year}

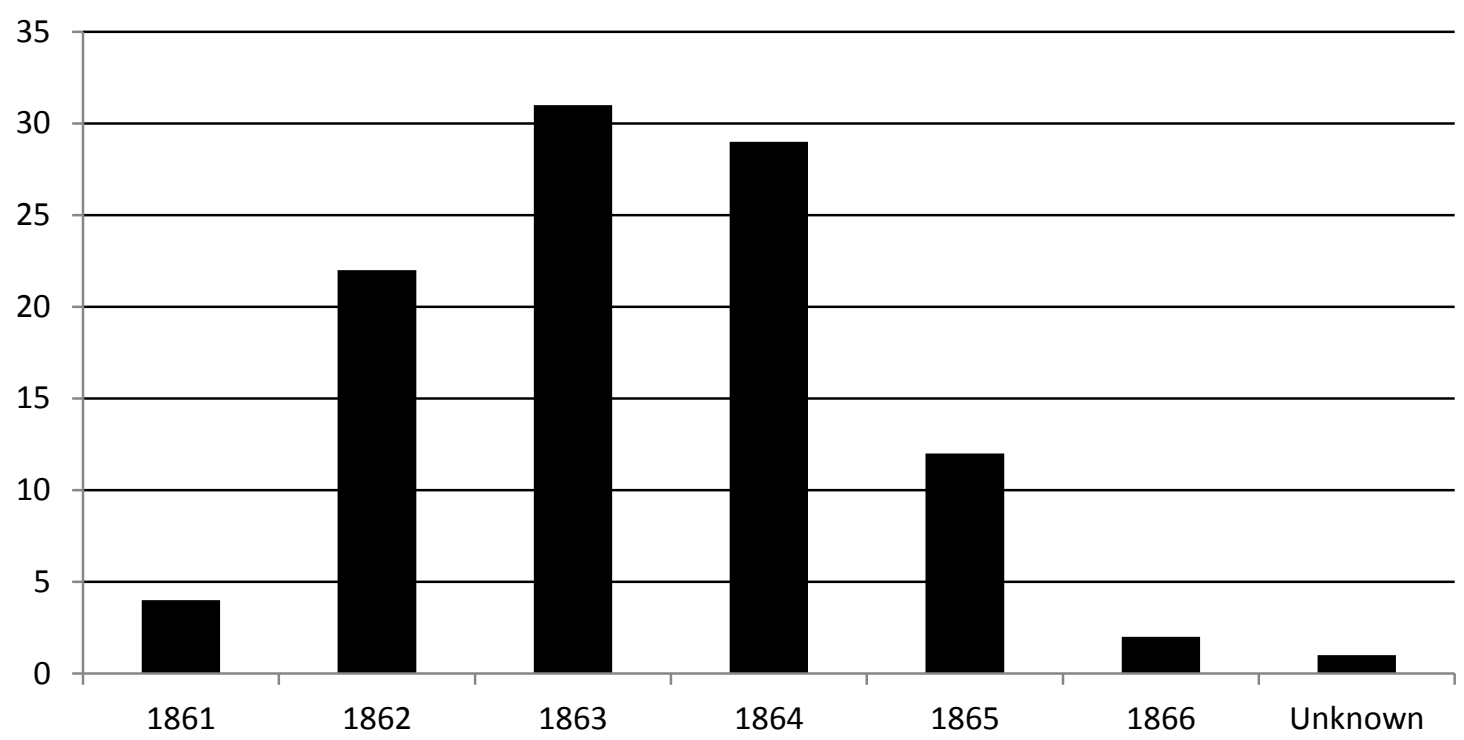

\begin{tabular}{|c|c|}
\hline Year & Number of Identified Suicides \\
\hline 1861 & 4 \\
\hline 1862 & 22 \\
\hline 1863 & 31 \\
\hline 1864 & 29 \\
\hline 1865 & 12 \\
\hline 1866 & 2 \\
\hline Unknown & 1 \\
\hline
\end{tabular}

Figure C: Suicides By Year

Of the suicide cases I identified, the largest numbers came in 1863 and 1864.

Besides a continuation of the issues experienced in 1862, warfare was changing. These years saw the introduction of continuous campaigns; unlike the spaced out battles of the early war years, soldiers now fought continually for weeks or months at a time. In these campaigns battles lasted longer, meaning that soldiers spent more time on the same fields faced with the carnage, wounded, and dead of the previous days, and fought increasingly with assaults on entrenched positions. The terrain of some of these battlefields denied the 
possibility of quick victories and created a confusing and terrifying environment for the men fighting in it. ${ }^{12}$ For example, the terrain of the Wilderness in northern Virginia was a terrifying location in which soldiers fought two battles. Fighting in the woods created confusion during the battle, but it also brought the danger of fire which prompted veteran Frank Wilkeson to recount scenes from the Battle of the Wilderness after the war:

The wounded soldiers lay scattered among the trees. They moaned piteously. The unwounded troops, exhausted with battle, helped their stricken comrades to the rear. The wounded were haunted with the dread of fire. They conjured the scenes of the previous year, when some wounded men were burned to death, and their hearts wellnigh ceased to beat when they thought they detected the smell of burning wood in the air. The bare prospect of fire running through the woods where they lay helpless, unnerved the most courageous of men, and made them call aloud for help. I saw many wounded soldiers in the Wilderness who hung on to their rifles, and whose intention was clearly stamped on their pallid faces. I saw one man, both of whose legs were broken, lying on the ground with his cocked rifle by his side and his ramrod in his hand, and his eyes set on the front. I knew he meant to kill himself in case of fire- - knew it as surely as though I could read his thoughts. ${ }^{13}$

For two days the armies struggled at the Wilderness, resulting in 30,000 casualties. Fires did indeed rage through the woods and claimed the lives of many wounded soldiers who could not get away. A new level of terror was added to battle.

This mode of warfare was grueling on the soldiers, wearing them down continuously. ${ }^{14}$ Writing about the later years of the war, Historian Earl J. Hess wrote that the effect of continuous campaigning on soldiers was dramatic:

Previous pitched battles had been traumatic experiences, but the rank and file had always had an opportunity to recuperate between confrontations. Now they had no time to physically rest or recover their spirits. Campaigning in the field was never easy; now it drove men to the breaking point. Continuous marching, digging entrenchments, skirmishing, repelling or launching frontal assaults, hastily burying the dead, and beginning the cycle of combat all over again was the rule for months. ${ }^{15}$

\footnotetext{
${ }^{12}$ Earl J. Hess, The Union Soldier in Battle, 39-40, 64-65; Gerald Linderman, Embattled Courage, 140-142, 180-182, 201-215.

${ }^{13}$ Frank Wilkeson, Recollections of a Private Soldier in the Army of the Potomac (New York and London: G.P. Putnam's Sons, 1887): 66-67.

${ }^{14}$ Earl J. Hess, The Union Soldier in Battle, 64-65; Eric T. Dean, Jr., Shook Over Hell, 76.
} 
This left the men exhausted and combat inefficient; Oliver Wendell Holmes, Jr. said of Grant's Virginia 1864 campaign that "many a man has gone crazy since this campaign began from the terrible pressure on mind \& body." For men that had enlisted in 1861 or 1862 these continuous campaigns of 1863 and 1864 were coming after years in the field, when the vulnerability created from changes in themselves and their support structure, the weariness of soldiering, and the losses of comrades had already set in. Eric Dean reports that one lesson learned from World War II was that "every man has his breaking point," every man is at risk from environmental stress. Psychiatric staff during that war determined that American troops lost their effectiveness after one hundred days of intermittent exposure to battle, and that breakdown could be expected after about two hundred total days. These totals might not be accurate for the Civil War, but the underlying psychology seems similar. Men broke down after a period of exposure to battle, some more acutely than others. The new style of warfare in the late war period might have accelerated that process. ${ }^{16}$

For Henry Paff of the $77^{\text {th }}$ Illinois Infantry, the 1863 Vicksburg campaign may have led to his breaking point. His regiment was part of the wing of Grant's force sent to capture Vicksburg while the other wing kept Confederate forces pinned in the northern part of the state. Traveling from December 20, 1862 to December 27, 1862, they were then engaged until January 11, 1863, seeing their first real combat and regimental losses. That winter, in addition to the unsanitary, muddy, and disease-ridden existence in camp, Grant pushed through a series of Bayou Expeditions, all of which failed. Once warmer weather returned the regiment was in constant motion, marching, traveling, performing

\footnotetext{
${ }^{15}$ Earl J. Hess, The Union Soldier in Battle, 67.

${ }^{16}$ Earl J. Hess, The Union Soldier in Battle, 67; Eric T. Dean, Jr., Shook Over Hell, 37, 75-76.
} 
picket duty, and fighting in battle from April 16, 1863 when they broke camp at Miliken's Bend to the fall of Vicksburg on July 4, 1863. Despite their victory, however, the men were not allowed to rest and they were back on the move the next day. When assigned to guard the wagon train on July 10, the men relished the opportunity for an "easier" duty; however, their major, perhaps seeking some personal glory, ensured his men were transferred back to the front lines the next day. They first held a position just behind the line and then in front of their main line, receiving enemy fire for over twentyfour hours. Sometime during that day, July 11, 1863, Corporal Paff committed suicide. ${ }^{17}$ With continual action and no time to recover Paff may have reached his breaking point quickly.

1864 is the year most known for continuous campaigns, the most famous of which are Grant's Overland Campaign in Virginia and Sherman's campaign in the south. Both campaigns would push the soldiers hard. "I'm getting tired of this kind of business," complained Jim Wilson in May, "for nearly three weeks now it has been march and fight all the time." ${ }^{, 18}$ Beginning in early May 1864, the Overland Campaign saw the Union and Confederate armies fight a continually southern-moving campaign until settling into a ten-month siege around Petersburg, VA in June. Writing in August, James Elliott reported that "on the height of Petersburg we remained there six weeks without being relieved ... our company is pretty well run down at this time."19 The campaign was broken in April 1865 in a series of movements that took the armies to Appomatox.

\footnotetext{
${ }^{17}$ Illinois. Military and Naval Department, Jasper N. Reece, and Isaac Hughes Elliott, Report of the Adjutant General of the State of Illinois, Volume IV, Containing Reports for the Years 1861-1866 (Springfield, IL: Phillips Bros, State Printers, 1901. GoogleBooks): 666; Terrence J. Winschel, The Civil War Diary of a Common Soldier, 25-65.

${ }^{18}$ Jim Wilson to Albert, May 18, 1864, SoldierStudies.org, accessed November 16, 2011.

${ }^{19}$ James Peters Elliott to George, August 7, 1864, SoldierStudies.org, accessed November 12, 2011.
} 
Lorenzo G. Babcock took his life May 6, 1864 near Todd's Tavern after the first engagement at the Wilderness and a few months later artilleryman Stephen Zoller committed suicide near Weldon Railroad as the armies settled into the siege of Petersburg. Campaigning through Georgia with Sherman, suicide was also the answer for Peter Jacot of the $16^{\text {th }}$ Illinois Cavalry; he killed himself on a battlefield near Atlanta, GA on July 31, 1864. A few months later William Hoerhold did the same; comrades estimated that they had spent forty-two days engaged in the siege of Atlanta and lost onefifth of the army before taking possession of the city. ${ }^{20}$

By charting the suicide cases following roughly defined campaign seasons - the months April to September usually saw more fighting than the months October to March - it is clear that battle was not the only factor influencing suicidal decisions (Figure D). There is a marked rise between the winter and campaign seasons in 1862 and 1863. However, distinct changes in numbers are absent for 1864 and 1865 when the

\footnotetext{
${ }^{20}$ Lorenzo G. Babcock: Annual Report of the Adjutant-General of the State of New York For the Year 1903. Registers of the One Hundred and Twenty-first, One Hundred and Twenty-second, One Hundred and Twenty-third, One Hundred and Twenty-fourth, One Hundred and Twenty-fifth, One Hundred and Twentysixth and One Hundred and Twenty-seventh Regiments of Infantry (Albany: Oliver A. Quayle, State Legislative Printer, 1904): 672, http://dmna.state.ny.us/historic/reghist/civil/rosters/Infantry/125th_Infantry_CW_Roster.pdf; Stephen Zoller: Annual Report of the Adjutant-General of the State of New York For the Year 1897. Register of the Fifteenth and Sixteenth Artillery in the War of the Rebellion (New York and Albany: Wynkoop Hallenbeck Crawford Co., State Printers, 1898): 420, http://dmna.state.ny.us/historic/reghist/civil/rosters/Artillery/16thArtCW_Roster.pdf; Peter Jacot: Illinois. Military and Naval Department, Jasper N. Reece, and Isaac Hughes Elliott. Report of the Adjutant General of the State of Illinois, Volume VIII. Containing Reports for the Years 1861-1866 (Springfield: Journal Company, Printers and Binders, 1901. GoogleBooks): 543; William Hoerhold: Annual Report of the Adjutant-General of the State of New York. For the Year 1904. Registers of the One Hundredth and FortySeventh, One Hundred and Forty-Eighth, One Hundred and Forty-Ninth, One Hundred and Fiftieth, One Hundred and Fifty-First, One Hundred and Fifty-Second, One Hundred and Fifty-Third, One Hundred and Fifty-Fourth, and One Hundred and Fifty-Fifth Regiments of Infantry (Albany: Brandow Printing Company, State Legislative Printers, 1905): 598, http://dmna.state.ny.us/historic/reghist/civil/rosters/Infantry/150th_Infantry_CW_Roster.pdf; Richard T. VanWyck, A War to Petrify the Heart: The Civil War Letters of a Duchess County, N.Y. Volunteer. Edited by Virginia Hughes Kaminsky (Hensonville, NY: Black Dome Press, 1997): 253-259, US Army Heritage and Education Center, PA; S.G. Cook and Charles E. Benton, ed. The "Dutchess County Regiment" $\left(150^{\text {th }}\right.$ Regiment of New York State Volunteer Infantry) in the Civil War; Its Story as Told by its Members (Danbury, CT: The Danbury Medical Printing Co., Inc., 1907): 106, 120, 127-128; Charles E. Benton, As Seen From the Ranks: A Boy in the Civil War (New York: G.P. Putnam's Sons, 1902): 209.
} 
combat pressure on soldiers increased. These figures suggest that there were other factors beyond battle influencing a soldier's mental state and tendencies toward selfharm. Experiences as wounded casualties and prisoners of war affected soldiers, as did age and time spend in the military.

\section{Suicide by Campaign Season}

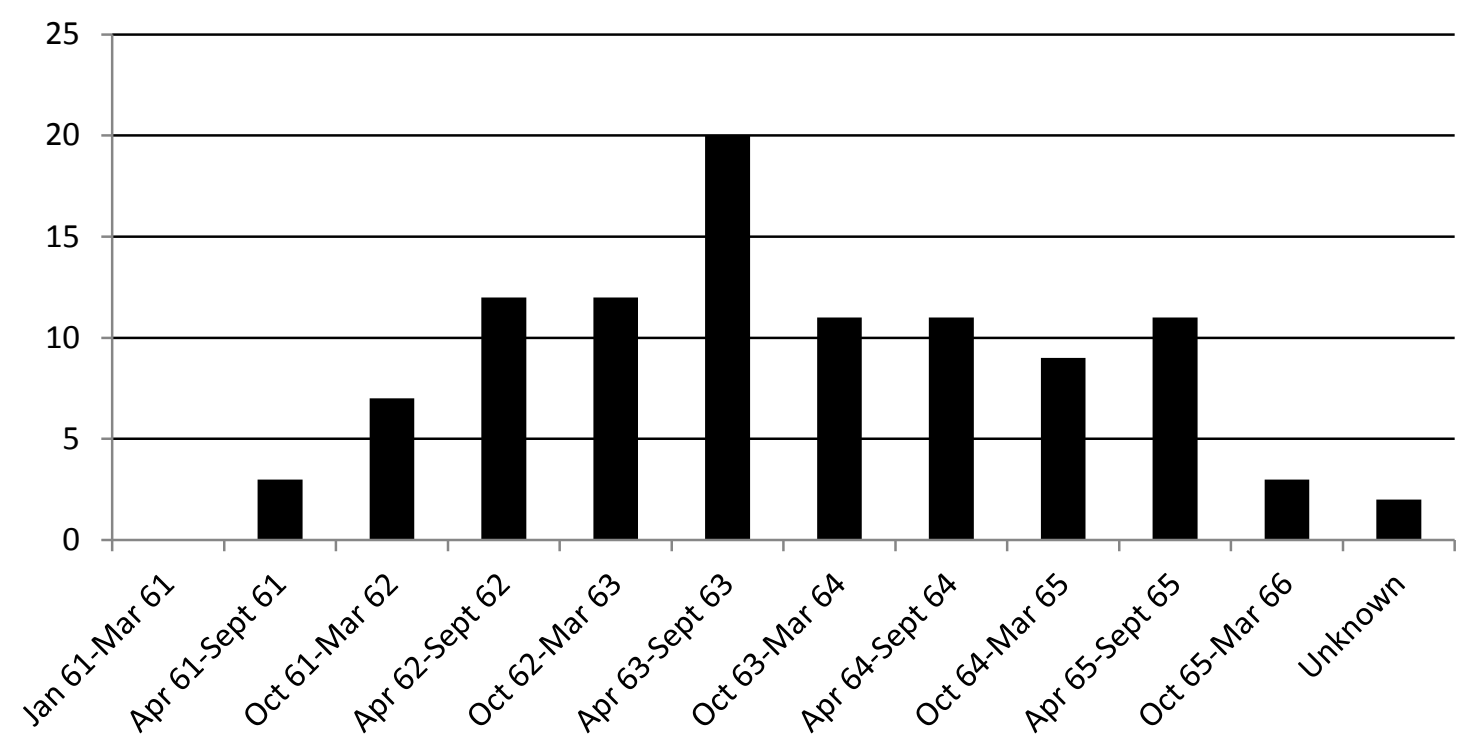

Figure D: Suicides by Campaign Season

For some soldiers, the battle continued long after the smoke cleared. The wounded could lie on the field for hours or even days before anyone could come to their aid, suffering from dehydration and pain. Even when they were rescued, wounded men were taken to field hospitals, temporary structures, barns, or houses where overworked, undertrained, and undersupplied doctors tried to keep up with the stream of casualties coming off the field. The sights, sounds, and smells of a hospital with its infected wounds, amputations, and slow deaths were unnerving to soldiers and the hasty burial of the dead made most soldiers try to avoid hospitals completely. "God save me from being 
sick and having hospital care such as I have seen," commented George Taylor. Men saw hospitals as places of indifference where surgeons were careless and soldiers faced neglect and a lonely death, making most pray that they would never have to go to one. ${ }^{21}$ These conditions were enough to drive men to despair. A "Mr. B" writing to friend and hospital matron Elvira J. Powers wrote of a hospital ward in Newark, New Jersey: "Last week, I am told, two men became so disgusted with the place, that one shot himself and the other hung himself, and others are thinking seriously of the same thing." 22

Illness or wounds certainly influenced some men in their decision to commit suicide. For some soldiers, the decision to commit suicide came after a period of affliction. Henry Johnson was left behind at the hospital at Camp Butler when his regiment left for the front and there he drowned himself in a nearby lake before he could rejoin them. Kimball Wellington of the $161^{\text {st }}$ New York Infantry committed suicide at a Regimental Hospital and Casper Diatz killed himself at a Fifth Corps Hospital. Francis Steck, in a hospital after the Battle of Chancellorsville in May 1863 was sent to the Government Hospital for the Insane in Washington where he drowned himself on October 21,1863 . A private of the $157^{\text {th }}$ New York Infantry who was attached to the Invalid Corps after an unknown affliction also killed himself. Another soldier, Alexander Anderson, was listed in the adjutant report as "shot himself, fit of insanity at Memphis, June 27, ' 62 ” but a history of his artillery battery provides a different story. That account reads: "During our march to Memphis, Alex. Anderson ... was taken alarmingly sick, and immediately on our arrival at Memphis, was placed in the Gayoso Hospital ... He

\footnotetext{
${ }^{21}$ Reid Mitchell, Civil War Soldiers, 61-64; Earl J. Hess, The Union Soldier in Battle, 32-33; Gerald F. Linderman, Embattled Courage, 128-133; Mark H. Dunkleman, Brothers One and All, 116 (quote).

${ }^{22}$ Elvira J. Powers, Hospital Pencilings: Being a Diary While in Jefferson General Hospital, Jeffersonville, Indiana and Others at Nashville, Tennessee as Matron and Visitor (Boston, MA: E. L. Mitchell, 1866; Accessed February 3, 2011, American Civil War Diaries and Letters): letter is February 19, 1865.
} 
became violently insane, and, breaking away from the attendants, jumped from the fourth story window, landing on the hard pavement below." He died shortly after from his injuries. For these soldiers, their illness and pain or frustrations with feeling not whole or helpless may have influenced their actions. ${ }^{23}$ This may be best illustrated by the case of New Yorker John Rabus. When Rabus committed suicide in Philadelphia six months after he was discharged for disability from Mower General Hospital he left behind a rare suicide note that was preserved by publication in Harper's Weekly:

I was a soldier in the Fifteenth New York Heavy Artillery, U.S.A., and I got a disease (palsy) in the service, from the effects of which I was obliged to stop work; in consequence I applied for a pension from the United States Government. Not receiving any support from the government, this is to inform my friends and acquaintances I have been obliged to kill myself.

$$
\text { John Rabus, from Gotha. }{ }^{24}
$$

Rabus expressed hopelessness in his inability to support himself, blaming his suicidal actions on a government who would not relieve his situation.

\footnotetext{
${ }^{23}$ Henry Johnson: Albert O'Connell Marshall, "Memoir of Albert O'Connell Marshall,” 30-31; Illinois. Military and Naval Department, Jasper N. Reece, and Isaac Hughes Elliott, Report of the Adjutant General of the State of Illinois, Volume II, Containing Reports for the Years 1861-1866 (Springfield, IL: Phillips Bros, State Printers, 1900. Google Books): 614; Kimball Wellington: Annual Report of the AdjutantGeneral of the State of New York For the Year 1904. Registers of the One Hundred and Fifty-Sixth, One Hundred and Fifty-Seventh, One Hundred and Fifty-Eighth, One Hundred and Fifty-Ninth, One Hundred and Sixtieth, One Hundred and Sixty-First, One Hundred and Sixty-Second, One Hundred and Sixty-Third, One Hundred and Sixty-Fourth, One Hundred and Sixty-Fifth, One Hundred and Sixty-Sixth and One Hundred and Sixty-Seventh Regiments of Infantry (Albany: Brandow Printing Company, State Legislative Printers, 1905): 804, http://dmna.state.ny.us/historic/reghist/civil/rosters/Infantry/161st_Infantry_CW_Roster.pdf ; Casper Diatz: Annual Report of the Adjutant-General of the State of New York For the Year 1897. Register of the Fifteenth and Sixteenth Artillery in the War of the Rebellion (New York and Albany: Wynkoop Hallenbeck Crawford Co., State Printers, 1898): 71, http://dmna.state.ny.us/historic/reghist/civil/rosters/Artillery/16thArtCW_Roster.pdf; Francis Steck: Eric T. Dean, Jr., Shook Over Hell, 122; Unnamed: “Army and Navy Items," Harper's Weekly, February 13, 1864, 99, HarpWeek, Accessed February 4, 2011; Alexander Anderson: Charles B. Kimball, History of Battery “A," 51; Illinois. Military and Naval Department, Jasper N. Reece, and Isaac Hughes Elliott, Report of the Adjutant General of the State of Illinois, Volume III, Containing Reports for the Years 1861-1866 (Springfield, IL: Phillips Bros, State Printers, 1901. Google Books): 544.

24“"Domestic Intelligence: News Items." Harper's Weekly, April 7, 1866, 222. HarpWeek, Accessed February 4, 2011; Annual Report of the Adjutant-General of the State of New York. For the Year 1897. Registers of the Fifteenth and Sixteenth Artillery in the War of the Rebellion (New York and Albany: Wynkoop Hallenbeck Crawford Co., State Printers, 1898): 289.
} 
Other soldiers made more immediate decisions about suicide, quickly weighing the pain and danger of their situation. Told that he only had a few hours to live due to mortal wounds received at Antietam, a sergeant shot himself with a revolver, perhaps not willing to suffer the pain with no hope of recovery. One wounded soldier did not even make it off the battlefield before he took his own life. At Fredericksburg, Thomas H. Evans of the $12^{\text {th }}$ US Regulars reported passing over the battlefield on Marye's Heights immediately after the engagement, hearing a shot, and then finding a body with a rifle lying across it, powder burns on the clothing, and the head shattered from the chin upwards. Evans wrote: "He had probably mistaken our approach for a body of the enemy, and in his agony and horror of becoming a wounded prisoner, had blown out the remains of his life by his own act."25

The Fredericksburg soldier had reason to fear becoming a prisoner of war for they were another group that faced particular traumas. Early in the war, prisoners were usually kept only for a few days before being paroled. Soldiers, although enemies, felt a certain bond through their shared experience, so prisoners were usually treated well by front-line soldiers. Later in the war, however, the system collapsed over disputes about how to deal with African-American prisoners. Prisoner exchanges came to a halt and led to extended situations in prisons such as Andersonville, Georgia and Elmira, New York. While POWs were still treated civilly on the frontlines, they faced harsher treatment by the soldiers controlling prison camps. In the unfortunate circumstances of these camps, prisoners had inadequate shelter, clothing, food, and little stimulation. ${ }^{26}$

\footnotetext{
${ }^{25}$ Earl J. Hess, The Union Soldier in Battle, 90; Thomas H. Evans, “The Cries of the Wounded," 33.

${ }^{26}$ Gerald Linderman, Embattled Courage, 236-239; Eric T. Dean, Jr., Shook Over Hell, 81-83.
} 
The foundations soldiers clutched to manage their wartime experiences completely broke down in the environment of prisoner camps, even breaking the bonds of camaraderie so crucial to surviving camp life and battle. Deprivation, monotony, cruelty, disease, and death forced some prisoners to sink into apathy and face long-standing psychological and physical issues and others to consider or commit suicide. Francis Amasa Walker wrote of his time as a prisoner of war that he suffered "a period of nervous horror such as I had never before and have never since experienced, and memories of which have always made it perfectly clear how one can be driven on, unwilling and vainly resisting, to suicide. I remember watching the bars at my window and wondering whether I should hang myself from them."27 Walker resisted such temptation, but others could not, despite the restrictions of available materials in the prison camp. One cavalryman tried to cut his throat with a dull knife and another man used his suspenders as a noose. The "dead line" was an apparently popular form of committing suicide; this was a perimeter set up at many prison camps, either an imaginary line or marked in ways such as the "narrow strip of board nailed on uprights running about the enclosure" described by one Andersonville inmate. This marked the point prisoners could not pass without being shot by the guards. "One step over," wrote Austin Carr in 1864, "and the penalty is death." 28 For prisoners with no other means of ending their lives, this was an opportunity to have others do it for them. There are reports of several men purposely stepping over that line, including one whose mission failed when the guard refused to shoot him. There is no question that these men wanted death; one soldier stepped over the line and challenged the sentry to shoot him, after two failed

\footnotetext{
${ }^{27}$ Gerald Linderman, Embattled Courage, 260.

${ }^{28}$ Austin Carr diary (excerpted transcript), US Army Heritage and Education Center, Carlisle, PA, The Harrisburg Civil War Round Table Collection, Box 7.
} 
shots he yelled at the guard to do his duty and the third shot hit him in the head, killing him instantly. ${ }^{29}$

\section{Suicides Over the Course of the War}

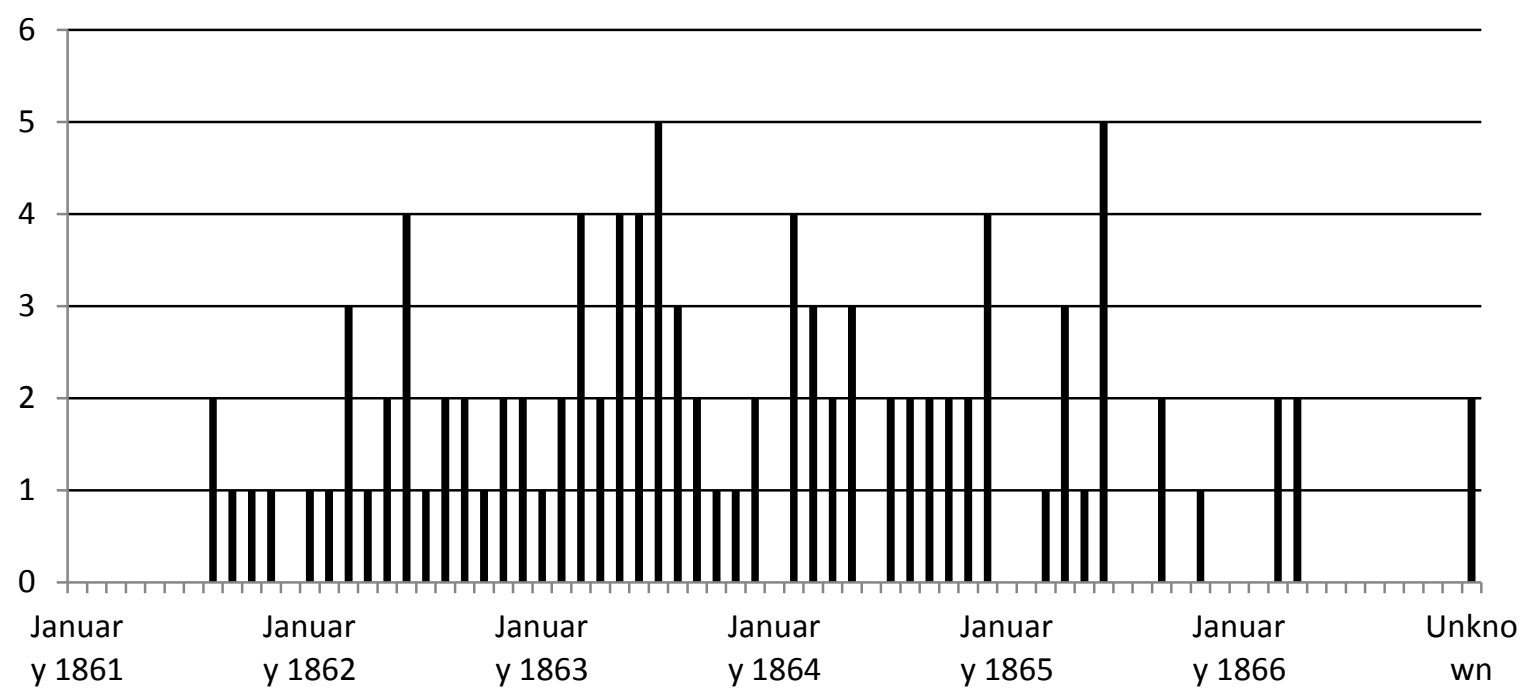

Figure E: Suicides Over the Course of the War

Moving away from specific stressors and looking at patterns of suicide on a wider scope, matters of time play a large role. When plotting the suicides over the course of the war (Figure E) the suicides have slight variations in rate throughout the war, starting low in 1861, escalating in 1863 (as previously discussed) and thinning out again after 1865. The two highest rates appear in July 1863 and in June 1865. The timing of these increases represent times of victory for the Union army, coming after Gettysburg and Vicksburg and again after the end of the war. It seems ironic that the suicide rate would peak during times of victory, but July 1863 and June 1865 also represent the end of long, hard campaigns when men had been pushed to their limits. It is interesting though that

\footnotetext{
${ }^{29}$ William Marvel, Andersonville, 157, 190; Eric T. Dean, Jr., Shook Over Hell, 81, 83; Alfred Lyth, "The Andersonville Diary of Private Alfred Lyth," Niagra frontier 8, no. 1 (1961): 22; Gerald Linderman, Embattled Courage, 257-261.
} 
the end of the war, a time when soldiers would be looking forward to returning home to family and civilian life, would also see a suicide spike.

When broken down by month (Figure F) two increases appear once again, in March and in June. An increase in suicides in March might result from the winding down of the winter encampment, which was often dull and occurred under poor conditions, and the approach of a new campaign season which was not close enough to increase morale but close enough to contemplate. The increased morale that usually occurred at the beginning of a campaign could explain the dip in April and May, while another rise in June could be evidence of that morale beginning to wear off as the campaign continued. ${ }^{30}$

In terms of enlistment, men who enlisted in the first year of the war saw the greatest rate of suicide (Figure G). This figure can be misleading, however, because not every soldier enlisted during 1861 or even 1862 . Men enlisted during the entire war, including an influx in 1864 as three-year enlistments ended, and recruitment continued even into $1865 .^{31}$ By instead breaking down the figures into the number of months between enlistment and death by suicide, an interesting pattern appears (Figure H). The shortest enlistment time was a matter of days and the longest was a full forty-eight months; however, most suicides occurred within the first year of service and the highest rates occurred at three months and two months, respectively. The second year saw much lower numbers, and there were very few past the two-year mark. It can be concluded from these figures that the adjustment to war was the hardest period, no matter when a

\footnotetext{
${ }^{30}$ Eric T. Dean, Jr., Shook Over Hell, 213.

${ }^{31}$ Benjamin Apthorp Gould, Investigations in the Military and Anthropological Statistics of American Soldiers (New York: Published for the U.S. Sanitary Commission, by Hurd and Houghton; Cambridge: Riverside Press, 1869): 5.
} 


\section{Suicides By Month}

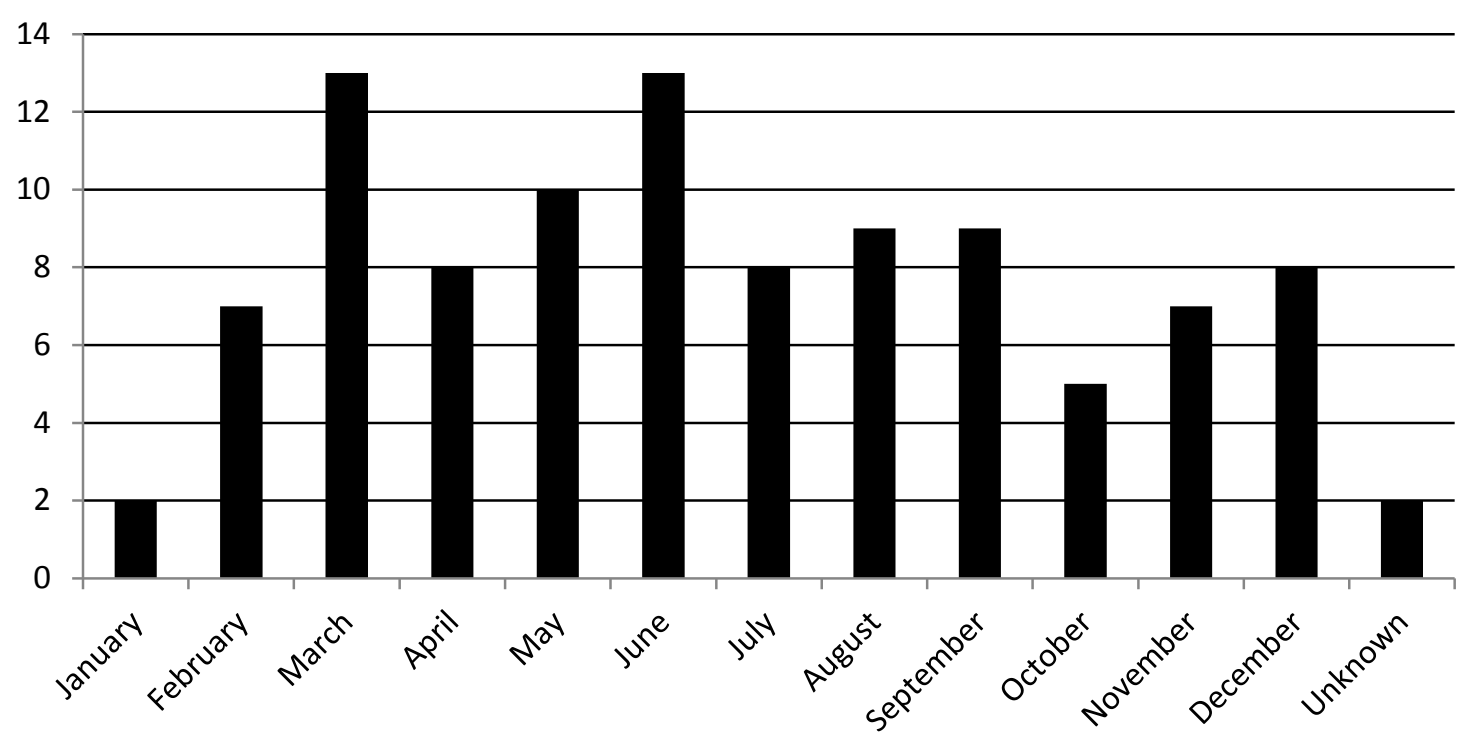

\begin{tabular}{|c|c|}
\hline Month & Number of Identified Suicides \\
\hline January & 2 \\
\hline February & 7 \\
\hline March & 13 \\
\hline April & 8 \\
\hline May & 10 \\
\hline June & 13 \\
\hline July & 8 \\
\hline August & 9 \\
\hline September & 9 \\
\hline October & 5 \\
\hline November & 7 \\
\hline December & 8 \\
\hline Unknown & 2 \\
\hline
\end{tabular}

Figure F: Suicide Cases By Month

soldier enlisted. During the time when men were undergoing the transformation from civilian to soldier, in which their priorities, expectations, responsibilities, experiences, and fundamental identity were changing, they were most at risk of suicide. 


\section{Suicides By Enlistment Year}

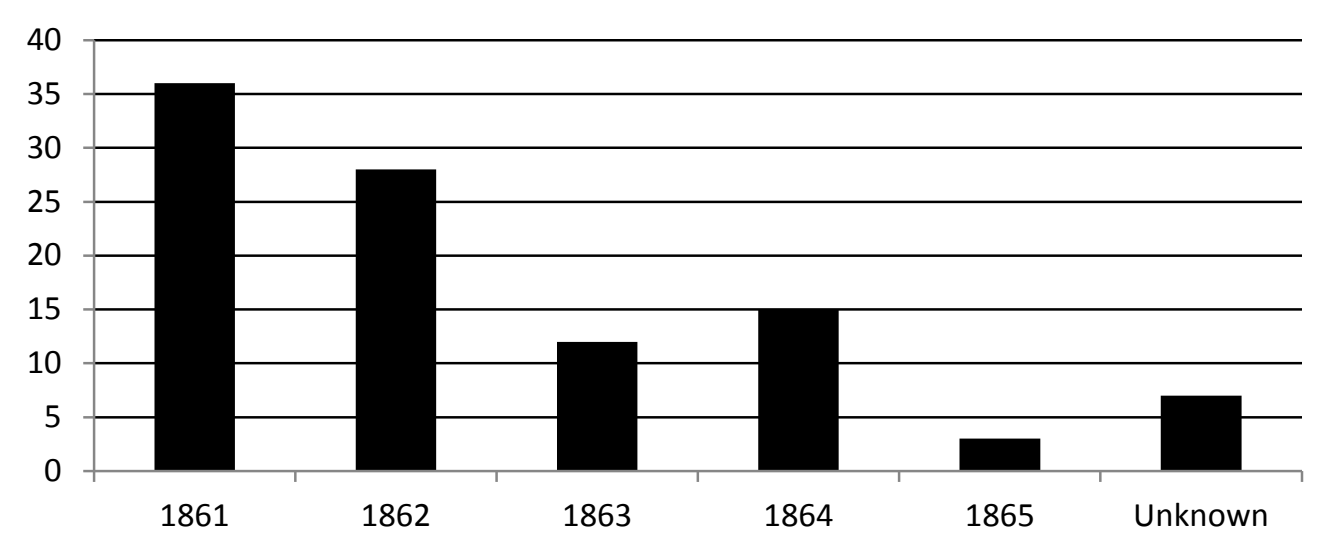

\begin{tabular}{|c|c|}
\hline Year of Enlistment & Number of Identified Suicides \\
\hline 1861 & 36 \\
\hline 1862 & 28 \\
\hline 1863 & 12 \\
\hline 1864 & 15 \\
\hline 1865 & 3 \\
\hline Unknown & 7 \\
\hline
\end{tabular}

Figure G: Suicides by Enlistment Year

\section{Suicides by Months from Enlistment to Death}

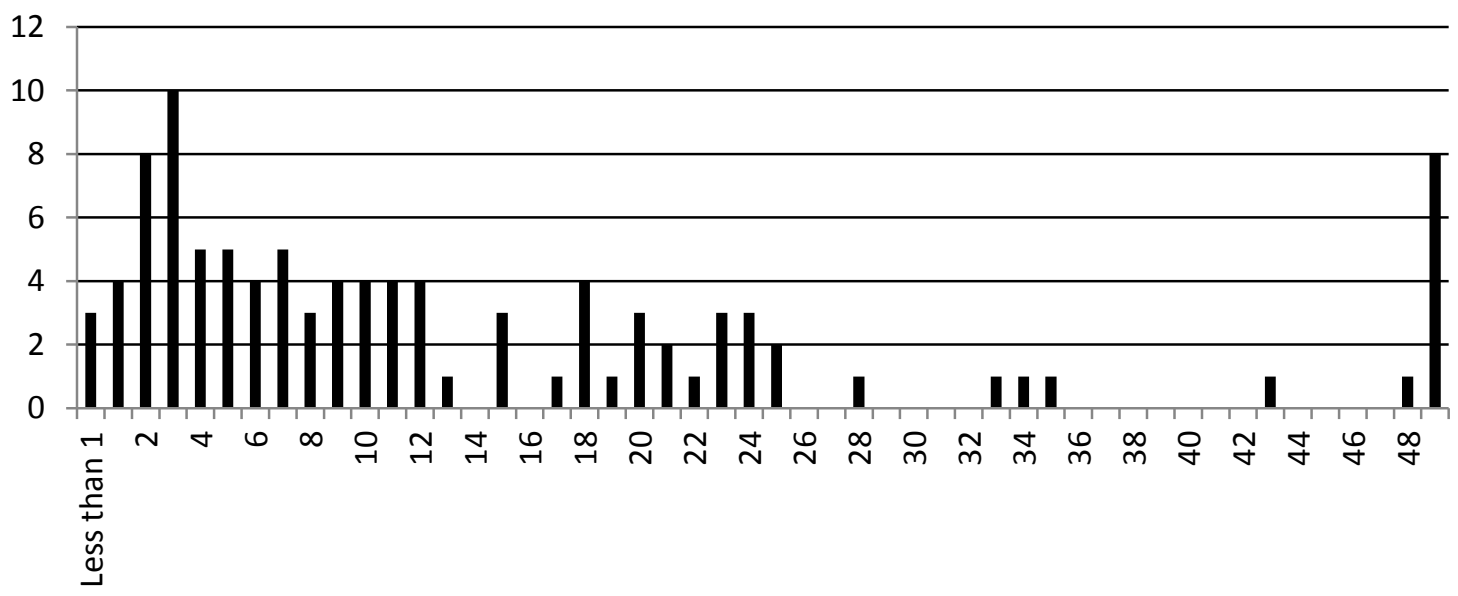

Figure H: Time Between Enlistment and Death By Suicide

\{The last figure represents the unknown cases. Figures are calculated to represent total completed months between enlistment and death; for example, if a soldier enlisted on August 20, 1862 and died July 12, 1863 (as Frank Kimberly did) he would be represented under 10 months because he did not live until July $20^{\text {th }}$ to complete the $11^{\text {th }}$ month. These were calculated from the first known enlistment date of a soldier; in some cases more than one enlistment is represented in a figure.\} 
Eric Dean suggests that younger soldiers fared better with the transition into war because they were better able to adapt than older soldiers; he claimed that men eighteen to twenty-five experienced the fewest problems with mental trauma and that the odds of experiencing that trauma increased with age. ${ }^{32}$ On the contrary, a study by psychologists and doctors on the records of around 15,000 Civil War soldiers found that those who enlisted at an earlier age were more likely to show signs of cardiovascular, gastrointestinal, and/or nervous disease after the war. ${ }^{33}$ The youngest suicide in my sample was sixteen and the oldest forty-five, but the greatest volume occurred in soldiers who were in their twenties; thirty-four out of fifty-six cases in which the age was identified occurred between the ages of twenty-one and thirty (Figure I). ${ }^{34}$ These rates can be explained by their relationship with the average age of the Union army. While there was a significant group of soldiers under eighteen and some soldiers whose ages reached into the forties, fifties, and even sixties, the largest bulk of Union men were between the ages of eighteen and forty-five (roughly the same range as the suicide cases). In the first year of the war the largest age group was eighteen year olds (even allowing for those who lied about their age to enlist), followed by twenty-one years olds; after that the age groups steadily decreased in size. The estimated average age of the Union soldier ranged from 25.10 years old in July 1862 to 26.32 years old in May 1865; these averages

\footnotetext{
${ }^{32}$ Eric T. Dean, Jr., Shook Over Hell, 37.

${ }^{33}$ Judith Pizarro, Roxane Cohen Silver, and JoAnn Prause, "Physical and Mental Health Costs of Traumatic War Experiences Among Civil War Veterans," Arch Gen Psychiatry 63 (Feb 2006): 196-198.

${ }^{34}$ Only Massachusetts and New York reported the soldier's age in the adjutant reports; Ages are missing for soldiers from California, Connecticut, and Illinois, as well as some New Yorkers where the age was not specified.
} 
fall right in the middle of the twenty-one to thirty year old range which saw the most suicides in this data set. ${ }^{35}$

\section{Suicide Cases By Age in Years}

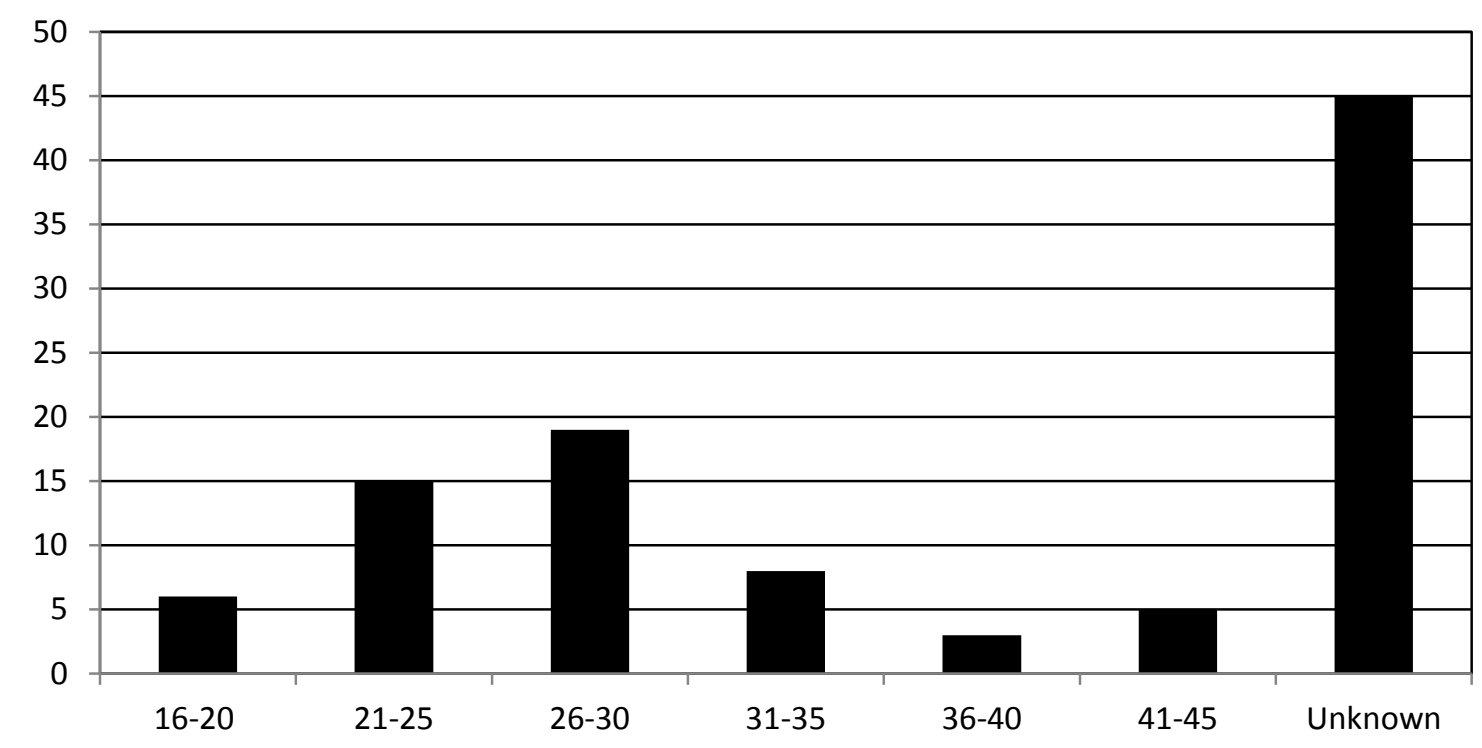

\begin{tabular}{|c|c|}
\hline Age Groups & Age of Suicides \\
\hline $16-20$ & 6 \\
\hline $21-25$ & 15 \\
\hline $26-30$ & 19 \\
\hline $31-35$ & 8 \\
\hline $36-40$ & 3 \\
\hline $41-45$ & 5 \\
\hline Unknown & 45 \\
\hline
\end{tabular}

Figure I: Suicide Cases by Age

\{Only Massachusetts and New York reported the soldier's age in the adjutant reports; Ages are missing for soldiers from California, Connecticut, and Illinois, as well as some New Yorkers where the age was not specified.\}

\footnotetext{
${ }^{35}$ Bell I. Wiley, The Life of Billy Yank: The Common Soldier of the Union (New York: The Bobbs-Merrill Company, 1951): 298-303.
} 


\section{Enlistments By Age}

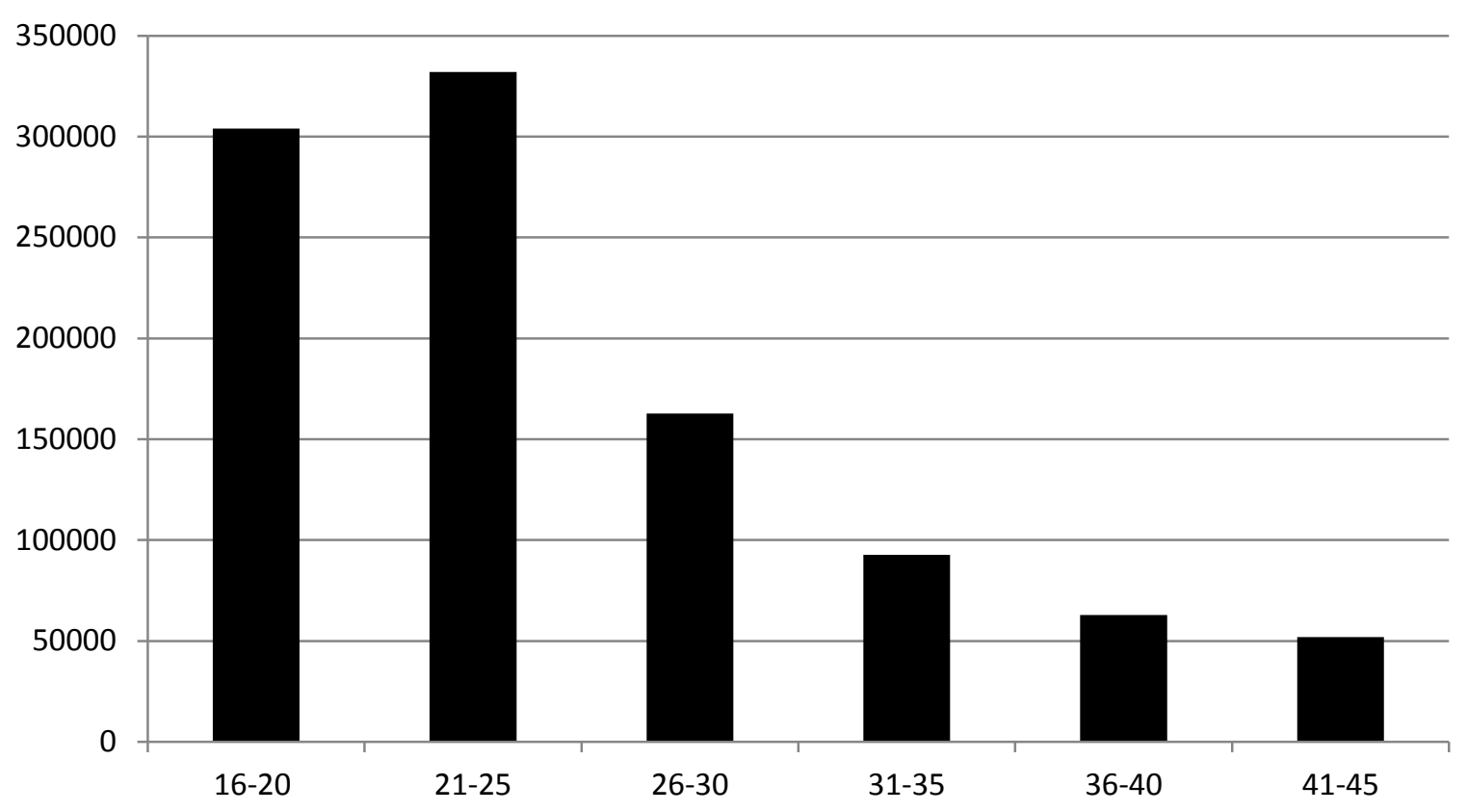

Figure J: Enlistments by Age

\{This data is taken from Benjamin Apthorp Gould, Investigations in the Military and Anthropological Statistics of American Soldiers. New York: Published for the U.S. Sanitary Commission, by Hurd and Houghton; Cambridge: Riverside Press, 1869, page 34.\}

When compared to age data from a sample of Union soldiers (Figure J), suicides in the sixteen to twenty-five range are indeed low. In the twenty-six to thirty range, however, enlistments fall to almost half of those between twenty-one and twenty-five but the suicide rate rises. From these figures, it seems that the youngest soldiers (up to age twenty) may have had fewer problems with mental stress during the war, even through that range included the largest single age group represented. The evidence supports Dean's assertion that eighteen to twenty-five year olds were most resilient even though we see the suicide numbers begin to rise rapidly after age twenty. However, his claim that the odds increased with older age is not entirely supported. After age thirty the number of suicides drops sharply off at such a rate that cannot simply be explained by 
lower representation in those older age groups. Even the slight rise in the forty-one to forty-five age bracket does not compare to the rate in the twenty-six to thirty year old range. The evidence drawn from my sample suggests that soldiers between the ages of twenty-six and thirty were the most at risk for suicide. Family situations possibly explain the particular vulnerability of this age group. Younger men, while still discovering their manhood and identity, were tied to their childhood households; they had deep connections to their parents and siblings. Older men connected deeply with families of their own with relationships to wives and children. In addition, older soldiers were more stable in their faith, identities, and cultural surroundings. As the next chapter argues, these cultural elements and connections to other people were crucial to surviving the war experience. The twenty-six to thirty age bracket represents men in between the two stable groups of older and younger soldiers. Their cultural identity was in transition and they were at a stage where connections to parental households were weakening while relationships with families of their own were not yet established. Thus, the tools many men used to manage their lives as a soldier were not as strong for that age group, as reflected by an increased suicide rate.

\section{Was Combat Experience Enough to Cause Suicide?}

The experiences of combat and military life were admittedly hard on the men volunteering for the Union army, but was that they enough to drive a man to selfdestruction? Every man was changed by being a soldier, and many experienced varying degrees of mental trauma and stress, but, as we have seen, the number of suicides was very low. Emile Durkheim was the first to theorize about suicide, publishing his book in 1897; as a sociological study his theory centers around the disruption of the individual by 
social forces. Of the four types of suicide he identifies, "altruistic" suicide is caused by a high level of integration into society which causes a loss of individuality and heightened willingness to sacrifice themselves to the interest of the group. ${ }^{36}$ Seen through this lens, the rate of soldier suicide should be higher; the lives of individuals were disrupted greatly by the forces of the war and the nature of the military required soldiers to think and act as units instead of individuals, despite their protestations. ${ }^{37}$ Edwin Shneidman, turns the focus inward, arguing that suicide is caused by intense psychological pain that he labeled "psychache," created when the routine pain and unhappiness that everyone experiences along with the joys of life is experienced in a heightened degree. ${ }^{38}$ An environment such as that experienced by Civil War soldiers certainly counts as one in which sorrow, shame, fear, dread, defeat, and anxiety are present in heightened levels. Similarly, Roy Baumeister argues that suicide is a form of escape when a person experiences a negative discrepancy between expectations and reality; soldiers held preconceived ideas of war which were shattered once they entered it. Exposure to trauma and the inability to develop ways to handle negative emotions factored into Marsha Lineham's theory of selfharm. When the normal mechanisms for regulating emotions have broken down, she argues, self-injury became a person's new mechanism. ${ }^{39}$ Again, these theories would

\footnotetext{
${ }^{36}$ Emile Durkheim, Suicide, for altruistic suicide see 217-240.

${ }^{37}$ Union soldiers valued their independence and autonomy, and hated the discipline and regimentation of military life; they were used to equality in their civilian lives and distained submitting to the will of an authority, especially if that authority was an officer whom they had been on an even footing with back home. Military punishment was seen as degrading manhood and freedom, and some made connections to enslavement; Reid Mitchell, Civil War Soldiers, 57-59; Lorien Foote, The Gentlemen and the Roughs: Manhood, Honor and Violence in the Union Army (New York: New York University Press, 2010): 147, 161; Gerald Linderman, Embattled Courage, 36-37.

${ }^{38}$ Edwin S. Shneidman, The Suicidal Mind (New York: Oxford University Press, 1996): 4, 6.

${ }^{39}$ Thomas Joiner, Why People Die By Suicide (Cambridge: Harvard University Press, 2005): 33-42; Gerald Linderman, Embattled Courage, 113.
} 
seem to indicate there should be a higher rate of Union suicides because each theory contains circumstances encountered and experienced by soldiers.

The interpersonal-psychological theory of suicide introduced by Thomas Joiner in his 2005 work Why People Die By Suicide, provides a foundation to explain why the rates of suicide were low among Union soldiers despite the presence of multiple stressors and evidence of mental trauma. There are many people who feel or exhibit signs of suicidality, but very few successfully commit the action. This is because there are three variables to a successful suicide_- perceived burdensomeness, failed belongingness, and the capability for self-harm — and without all three a suicide will fail. The first two factors deal with the interactions and connections between people, both of which Joiner identified as "fundamental needs." Humans need to interact with others as well as feel cared for; simple connections with many people and deep connections with specific people are very important. These relationships are mutual; when a person feels ineffective, helpless, and unable to contribute a sense of burdensomeness develops. Perceived burdensomeness and failed belongingness constitute the desire for death (which most people feel at some time in their life), but not the ability. This is the third variable: acquired capability for self harm. A body's natural instinct of self-preservation is very difficult to overcome, even if the desire to die is present; however, if a person becomes used to danger and self-injury (whether through harming themselves in gradually worse ways or being exposed to dangerous situations) then the danger signals that should accompany self-harm no longer occur. The destruction of this natural barrier 
allows those with the desire to die to actually go through with it; without it the idea would be dismissed or attempts would fail. ${ }^{40}$

Modern studies have demonstrated that soldiers can experience an increased capability for suicide because of exposure to the violence and death of combat and training in fighting and killing. Even if not actually committing acts of self-harm to acquire capability, exposure to violence is another way to habituate to pain. A Vermont private wrote, "The more we get used to being killed, the better we like it." The "hardening" process that accustomed soldiers to battle and death meant they would no longer fear it. A soldier who has suppressed their emotional responses to the war, has become desensitized to violence, has lost compassion for life, and seeks the relief of death may find it easier or more alluring to end his own life. Take, for example, the writings of Confederate soldier Thomas Hampton: "I rather believe if my friends knew the hardships that is incumbent on a soldier that they would scarcely begrudge a withdrawal from this Tabernacle of Mortality to that of Immortal Glory for which I often long to see." However, acquired capability alone does not create a basis for suicidality; perceived burdensomeness and failed belonging are necessary and these are not created by combat experience. ${ }^{41}$

A strong cultural support system combated disconnect and ineffectiveness, as will be discussed in the next chapter; there were times, however, when parts of the support system weakened. Soldiers were anxious to maintain connections with family at home to

\footnotetext{
${ }^{40}$ Thomas Joiner, Why People Die By Suicide, 46-136.

${ }^{41}$ Drew Gilpin Faust, This Republic of Suffering, 59 (Fisk quote), 176 (Hampton quote); Craig J. Bryan, et al, "Combat Experience and the Acquired Capability for Suicide," Journal of Clinical Psychology 66, no. 10 (2010): 1044-1056. This study used Joiner's theory to study modern servicemembers. They hypothesized that combat experience would predict acquired capability, but not perceived burdensomeness or thwarted belonging; their findings supported this hypothesis.
} 
help them bear the hardships of their military life and resist the new temptations they encountered; these connections would be vital for soldiers to continue feeling as though they belonged at home, even while they were far away. ${ }^{42}$ For some the trials of distance were too much. An example comes from a southern soldier (who, being a Confederate, is technically outside the scope of this study). David Funsten, a private in the $11^{\text {th }}$ Virginia Infantry, wrote to his wife in December 1861:

For a long time, I kept you all out of my thoughts, as much as possible, but when I began to think of a furlough \& you always the embodiment of every hop [sic] \& desire connected with it I found myself often overwhelmed as day after day \& week after week passes away without the expected leave of absence ... There was a young man from one of the Southern states who applied a few days ago for a furlough \& it was refused. He was afterwards on guard ... seeking an opportunity he stepped into a tent $\&$ blew his brains out. ${ }^{43}$

Funsten knew his own struggles with being away from his family and he connected them with the young soldier who killed himself after a failed attempt at receiving a furlough. We do not know if there was a specific reason the soldier wanted the furlough-if there was a crisis at home he may have felt ineffective as a husband and father-but denial of a chance to see and reconnect with his family seemingly led to his demise.

Soldiers experienced isolation from their families, and as that support system faded they turned to their comrades instead. A soldiers' mess became his family and his home; these comrades could understand what they felt because they were experiencing the same thing. Outside a soldier's personal group, identification with the regiment was crucial as well, an esprit de corps that surpassed almost any other ties, as Mark Dunkleman argues. The tight bonds of comradeship built through marching and camp life and the respect for a beloved officer helped a soldier in battle, knowing these men

\footnotetext{
${ }^{42}$ Eric T. Dean, Jr., Shook Over Hell, 92-93.

${ }^{43}$ Aaron Sheehan-Dean, Why Confederates Fought: Family \& Nation in Civil War Virginia (Chapel Hill: The University of North Carolina Press, 2007): 57-58.
} 
were fighting in line beside him, as well as through daily military life. This support structure could become a liability, however; as battle and disease continued to take their toll an increasing number of officers and comrades were absent from roll call. As more and more of the men with whom they had entered the war and built bonds with died or went away, a soldier started to feel very alone. After Chancellorsville, George Newcomb of the $154^{\text {th }}$ New York mourned the losses of his regiment. "All the boys that I used to associate with are gone," he wrote, then added a few days later, "It makes one feel lonesome to look at our little company." With increasing numbers of casualties reducing companies and regiments to well below strength, units were disbanded and consolidated. This process created dissatisfaction because it broke up the regimental identity so important to soldiers. Perhaps a broken esprit de corps is the answer behind the suicide of Dennis O’Donahue; he killed himself twelve days after his brigade was dissolved and scattered while serving in Florida, and four days after his regiment was also divided into two parts, each serving in different locations. ${ }^{44}$

Feeling disconnected from family and friends may explain why some soldiers committed suicide at the end of their enlistment or at the end of the war, at a time when most would be looking forward to returning to civilian life. Soldiers from any conflict can attest that reentering the civilian realm after military service is difficult. They were

\footnotetext{
${ }^{44}$ Eric T. Dean, Jr., Shook Over Hell: 92-93; Earl J. Hess, The Union Soldier in Battle, 109, 111-122, 126; Gerald F. Linderman, Embattled Courage, 234-236, 245-247; Mark H. Dunkleman, Brothers One and All, 5-6, 9-10, 94 (quote); Annual Report of the Adjutant-General of the State of New York. For the Year 1904. Registers of the One Hundredth and Fifty-Sixth, One Hundred and Fifty-Seventh, One Hundred and FiftyEighth, One Hundred and Fifty-Ninth, One Hundred and Sixtieth, One Hundred and Sixty-First, One Hundred and Sixty-Second, One Hundred and Sixty-Third, One Hundred and Sixty-Fourth, One Hundred and Sixty-Fifth, One Hundred and Sixty-Sixth, and One Hundred and Sixty-Seventh Regiments of Infantry (Albany: Brandow Printing Company, State Legislative Printers, 1905): 264, http://dmna.state.ny.us/historic/reghist/civil/rosters/Infantry/157th_Infantry_CW_Roster.pdf; Isabel Bracy, comp. $157^{\text {th }}$ New York Volunteer (Infantry) Regiment, 1862-1865, Madison and Cortland Counties, New York (Interlaken, NY: Heart of the Lakes Publishing, 1991): 48.
} 
different people from when they left and they had to reconstitute social norms that were broken out of the necessity of war. Charles L. Francke of $178^{\text {th }}$ New York Infantry killed himself on June 1, 1865 while his regiment was on guard duty near Montgomery, Alabama. He knew the war was over - the regiment had heard of Appomattox, the assassination of Lincoln, and knew "that the war was at an end"-yet Franke would not live to see home once again. ${ }^{45}$ Jonas Forsells was closer to home when he committed suicide. The $75^{\text {th }}$ Illinois arrived back in Chicago, Illinois on June 17, 1865 and settled at Camp Douglas to await final payment and discharge on July 1; on June 27 Forsells was dead. ${ }^{46}$ Some even killed themselves after long terms of service. New Yorker William Bowman served for all four years of the war (enlisting on August 20, 1861), but he committed suicide in September 1865, one month before the regiment was discharged. Bowman's situation suggests that extended time in the military — and thus time to grow accustomed and hardened to war-did not necessarily lead to an increased capability to survive the ordeal. ${ }^{47}$ One soldier even killed himself while home on furlough-we will

\footnotetext{
${ }^{45}$ Annual Report of the Adjutant-General of the State of New York. For the Year 1905. Registers of the One Hundredth and Seventy-Eighth, One Hundred and Seventy-Ninth, One Hundred and Eightieth, One Hundred and Eighty-First, One Hundred and Eighty-Second, One Hundred and Eighty-Third, One Hundred and Eighty-Fourth, One Hundred and Eighty-Fifth, One Hundred and Eighty-Sixth, and One Hundred and Eighty-Seventh Regiments of Infantry (Albany: Brandow Printing Company, State Legislative Printers, 1906): 35 , http://dmna.state.ny.us/historic/reghist/civil/rosters/Infantry/178th_Infantry_CW_Roster.pdf; Diary of Charles H. Tiedman, "D" Co. $178^{\text {th }}$ Regt. N.Y. Volunteers. Army Heritage and Education Center, Carlisle, PA. Civil War Miscellaneous Collection, Box 103; Stephen H. Smith diary. Army Heritage and Education Center, Carlisle, PA. Civil War Miscellaneous Collection, Box 96.

${ }^{46}$ Illinois Military and Naval Department, Jasper N. Reece, and Isaac Hughes Elliott, Report of the Adjutant General of the State of Illinois, Volume IV, Containing Reports for the years 1861-1866 (Springfield, IL:

Phillips Bros, State Printers, 1901): 45, GoogleBooks; William Sumner Dodge, A Waif of the War; Or, the History of the Seventy-fifth Illinois Infantry, Embracing the Entire Campaigns of the Army of the Cumberland (Chicago: Church and Goodman, Publishers, 1866): 210; Fred S. South, It Never Recoiled: A History of the Seventy-Fifth Illinois Volunteer Infantry, (Prophetstown, IL: 1995): 73.

${ }^{47}$ Annual Report of the Adjutant-General of the State of New York For the Year 1900. Registers of the Fifty-first, Fifty-second, Fifty-third, Fifty-fourth, Fifty-fifth and Fifty-sixth Regiments of Infantry (Albany: James B. Lyon, State Printer, 1901): 999, http://dmna.state.ny.us/historic/reghist/civil/rosters/Infantry/56th_Infantry_CW_Roster.pdf; Joel C. Fisk and William H.D. Blake, A Condensed History of the $56^{\text {th }}$ Regiment New York Veteran Volunteer Infantry,
} 
never know if his decision was due to a realization of how different his relationships with home had become or from a dread of going back to the front. ${ }^{48}$

On quite the opposite end of the spectrum, one suicide demonstrates that psychological issues could predate the war. The $109^{\text {th }}$ Illinois Infantry was mustered into service on September 11, 1862, among which was Andrew J. Bailey. Six days later Bailey was dead by his own hand, before the regiment had even moved from its camp. ${ }^{49}$ What is more disturbing is how he went about his suicide. Fellow volunteer, James Evans, wrote about Bailey's death:

A soldier belonging to Company D (Capt Andrews) while in a despondent state of mind, committed suicide by blowing his brains out with a revolver on Wednesday night of last week. He borrowed a pistol from one of the boys in camp saying he intended shooting some chickens. On going home he told his wife he intended to end his existence, and was determined that she should share his fate. Becoming frightened she fled from the room, when he deliberately placed the muzzle of the revolver to his head and fired. His own daughter, a little girl of some ten years, was the only witness of the sad deed. The unfortunate man lived but about an hour after receiving his wound. ${ }^{50}$

Which was a Part of the Organization Known as the "Tenth Legion" in the Civil War, 1861-1865 (Newburgh Journal Printing House and Book Bindery, 1906): 87, 96.

${ }^{48}$ Edwin Wilber, $44^{\text {th }} \mathrm{NY}$ Infantry: Annual Report of the Adjutant-General of the State of New York For the Year 1899. Registers of the Forty-fourth, Forty-fifth, Forty-sixth, Forty-seventh, Forty-eighth, and Fortyninth Regiments of Infantry (Albany: James B. Lyon, State Printer, 1901): 235,

http://dmna.state.ny.us/historic/reghist/civil/rosters/Infantry/44th_Infantry_CW_Roster.pdf; Eugene Arus Nash, A History of the Forty-fourth Regiment New York Volunteer Infantry in the Civil War, 1861-1865 (Chicago: R.R. Donnelley \& Sons Company, 1911): 466.

${ }^{49}$ Illinois. Military and Naval Department, Jasper N. Reece, and Jasper Hughes Elliott, Report of the Adjutant General of the State of Illinois, Volume VI. Containing Reports for the Years 1861-1866 (Springfield: Journal Company, Printers and Binders, 1900): 81, GoogleBooks; George E. Parks, "The Long Winter"; Being a Factual Narrative of One Story of the "Unusual" $109^{\text {th }}$ Regiment Volunteer Infantry of State of Illinois, 1862-1863 (Published in commemoration of the Centennial of the $109^{\text {th }}$ Regiment of Illinois Volunteer Infantry, 1963): ii.

50 Patrick Brumleve, ed., The Letters of James Evans, 2. Evans was slightly confused about the identity of the suicide. Captain Hugh Andrews was indeed captain in Company D; however he did not commit suicide and was discharged in April 1863. Andrew J. Bailey did commit suicide on September 17, suggesting that Evans mixed up whether Andrew was the first or last name. Interestingly, the records of both men list them as unmarried. "Illinois Civil War Muster and Descriptive Rolls Database." Illinois State Archives. www.ilsos.gov/genealogy/CivilWarController. Accessed February 17, 2012. 
Bailey's suicidal tendencies must have dated from before his August enlistment. His violence towards his wife and disregard for his young daughter suggest that he felt little of the connection expected between husband and wife or father and child. Perhaps he thought enlistment in the army would serve as some sort of remedy; when that failed, suicide was his escape.

Feelings of isolation within specific, deep relationships (primarily with family members) could be exasperated by disconnect with the body of citizens in the north. As soldiers experienced war they found that attempts to maintain pre-war ideas of warfare and behavior went unrealized. The war they expected to fight was not the war they experienced. Soldiers were changed by what they saw and did, and their civilian support system could not keep up with changes they did not also experience. As Gerald Linderman points out, there were two wars occurring at the same time: the war the soldier experienced and was changed by, and the war that civilians expected and saw. The initial respect and support soldiers felt from the homefront evolved into a sense of alienation; civilians could not understand the experiences of the soldier and the soldier could not effectively communicate to civilians what he did and saw. In some cases, alienation turned to resentment or bitterness towards civilians that appeared not to support the soldiers enough or prospered at home as soldiers suffered, and some soldiers even blamed the war on certain civilians, such as businessmen, service evaders, and peace Democrats. ${ }^{51}$ After the horror of Chancellorsville, Albinus Fell wrote that such scenes of

\footnotetext{
${ }^{51}$ Reid Mitchell, Civil War Soldiers, 64-68, 74; Eric T. Dean, Jr., Shook Over Hell, 92-93, 213; Gerald F. Linderman, Embattled Courage, 1-2, 79, 216-229; Earl J. Hess, The Union Soldier in Battle, 96-97, 156.
} 
war, "might of been closed but for the damned infernal God forsaken "Copperheads" dam em and may god dam their souls if they have any."

Experiencing disconnect in relationships relates to Joiner's concept of thwarted belongingness and feeling ineffective in one's military role could relate to perceived burdensomeness. Not every soldier was out on the front lines, although that is where most of them expected to be. The $11^{\text {th }}$ New York Cavalry (which saw the suicide of Lieutenant Frederick Starkey on June 13, $1863^{53}$ ) patrolled Washington D.C. and the surrounding areas for much of their enlistment; Company A even served as the bodyguard to President Abraham Lincoln. Despite their high-profile activities of policing the capital, they were unhappy with their inactivity, as voiced by Henry Murray Calvert:

Good material in men and skillful training by accomplished teachers, had made us worthy to charge for God and the Union on any battlefield. We believed in Scott's Nine Hundred, and felt sure that we should give a handsome account of ourselves against any body of horse of equal numbers that could be brought against us. For these reasons we longed to go to the front. But where was the prospect that we should be allowed to do this? Our life as a regiment was active along the lines in which we had for the most part volunteered. Were we to be kept as a sort of Household Cavalry about the home and person of the President, to be splendidly mounted, efficiently disciplined, commodiously housed, and live in comparative clover, while others were bearing the brunt of the fray in the field $?^{54}$

Guard or provost duty took men away from the action; the $85^{\text {th }}$ New York had been on guard duty for four months when Samuel Lindsay shot himself in the head with a revolver. ${ }^{55}$ By enlisting, men expected to be active in their cause, not sit relatively idle.

\footnotetext{
${ }^{52}$ Albinus R. Fell, letter of September 1, 1863. SoldierStudies.org, accessed November 29, 2011.

${ }^{53}$ Annual Report of the Adjutant-General of the State of New York For the Year 1894. Volume III. Registers of the $9^{\text {th }}, 10^{\text {th }}, 11^{\text {th }}$ and $12^{\text {th }}$ Regiments of Cavalry, N.Y. Vols., in the War of the Rebellion (Albany: James B. Lyon, State Printer, 1895): 961, http://dmna.state.ny.us/historic/reghist/civil/rosters/cavalry/11thCavCW_Roster.pdf; Thomas West Smith, The Story of a Cavalry Regiment, 73, roster.

${ }^{54}$ Henry Murray Calvert, Reminiscences of a Boy in Blue, 1862-1865 (New York: G.P. Putnam;s Sons, 1920): 23.

${ }^{55}$ Annual Report of the Adjutant-General of the State of New York. For the Year 1901. Registers of the Eighty-first, Eighty-second, Eighty-third, Eighty-fourth, Eighty-fifth, Eighty-sixth and Eighty-seventh
} 
By the end of 1864 , members of the $12^{\text {th }}$ Illinois Cavalry were dissatisfied when they continued to be held in service in Louisiana where a cavalry war no longer existedCharles Vimpany killed himself that November. ${ }^{56}$ Perhaps no Union soldiers felt this problem more keenly than those enlisted in California regiments. As Union men they too enlisted to assist the war effort, but most never saw combat. Instead their stories are filled with monotony, bad weather, an occasional skirmish with Indians or (maybe) Confederate sympathizers, and internal discipline when men lashed out against their boredom. They enlisted for a cause they never got a chance to fight for, many were stationed in Oregon away from their own state, and "like all soldiers the California volunteers in the Coast Range spent their time waiting for something exciting to happen. Nothing did. ${ }^{, 57}$ These men had all taken on the identity of soldiers, yet they were not sharing the experiences, responsibilities, and dangers of soldier life.

Many factors affected the Civil War soldier during their service in the Union army. Men found it stressful to undergo the change in identity from citizen to soldier. The living conditions of an army on the move, the jarring experience of killing and the danger of being killed, and the sometimes continuous, breaking pace of operations

Regiments of Infantry. (Albany: J.B. Lyon Company, State Printers, 1902): 1053, http://dmna.state.ny.us/historic/reghist/civil/rosters/Infantry/85th_Infantry_CW_Roster.pdf; Wayne Mahood, The Plymouth Pilgrims: A History of the Eighty-Fifth New York Infantry in the Civil War (Hightstown, NJ: Longstreet House, 1991): 138-149; Sally Andrews Earnest, ed. Letters of Stephen Tuppet Andrews, 96-97-interestingly Andrews comments on Lindsay's popularity, large circle of friends, and young wife which would not suggest a lack of belongingness; however, the wife and friends were back home in Black Creek, NY so the connections may have frayed more than Andrews was aware.

${ }^{56}$ Illinois. Military and Naval Department, Jasper N. Reece, and Jasper Hughes Elliott, Report of the Adjutant General of the State of Illinois, Volume VIII. Containing Reports for the Years 1861-1866. (Springfield: Journal Company, Printers and Binders, 1901): 347, GoogleBooks; Samuel M. Blackwell, Jr., In The First Line of Battle: The $12^{\text {th }}$ Illinois Cavalry in the Civil War (Dekalb, IL: Northern Illinois University Press, 2002): 147-148.

${ }^{57}$ California Adjutant General's Office, Records of California Men in the War of the Rebellion, 1861 to 1867, Compiled by Brig.-Gen. Richard H. Otten (Sacramento: J. D. Young, 1890): 92, 224, 250, 260, 292, 433, 456, 646, 871, 872, 877, 882, 883,GoogleBooks; Gunter Barth, ed., All Quiet On the Yamhill: The Civil War in Oregon, The Journal of Corporal Royal A. Bensell, Company D, Fourth California Infantry (Eugene, OR: University of Oregon Books, 1959): vii-ix, 116-117. 
pushed Civil War soldiers to their limits. The men who returned home at the end of their enlistments or the end of the war were not the same men who said goodbye to their families and friends at the beginning of their service. Many faced the challenges of mental or physical trauma, and all had to cope with the memories of what they had seen and done. However, a very small number of men ended their own lives, driven by the convergence of a number of variables. Most managed their experience and survived their time as a soldier, albeit a bit battered and scarred. What held the rest of the Union soldiers together, when some fell apart? 


\section{Chapter 3 \\ "Whether "tis Nobler in the Mind": The Soldier's "Cultural Toolbox" and Wartime Survival}

Writing from Marietta, Georgia in the midst of fighting around Kennesaw Mountain in July 1864, James B. McNeal of the $96^{\text {th }}$ Illinois Infantry stated that the "boys are in very good spirits and today this army is as large as when we left Cleveland, Tennessee and troops are coming up almost every day." Fierce, continuous campaigns characterized 1864, but despite constant fighting, heavy losses numbering over one hundred to that point in the campaign, miserably hot weather, and being a "dirty, lousy and ragged set of soldiers," McNeal could still write that he and his fellow soldiers were in good spirits. As he said, "who cared for a rent in the rear of his pants if his hide is whole." Keeping up one's spirits was important in order to continue fighting in the war. Moral upkeep and physical health kept the Civil War soldier going, but mental discipline was crucial as well. "More men die of homesickness than all other diseases," wrote Cyrus F. Boyd in February 1863, "and when a man gives up and lies down he is a goner. Keep the mind occupied with something new and keep going all the time except when asleep." ${ }^{2}$ Facing the hardships of military life, the experiences of battle, and months or years away from home, soldiers needed to keep themselves going. The majority of Union

\footnotetext{
${ }^{1}$ James B. McNeal to A.J. Rockwell, July 2, 1864. SoldierStudies.org, accessed November 12, 2011; Charles Addison Partridge, History of the Ninety-Sixth Regiment, Illinois Volunteer Infantry (Chicago: Historical Society of the Regiment, 1887. GoogleBooks, accessed December 2, 2011): 373. McNeal names the city Merinetta, GA, but the $96^{\text {th }}$ Illinois was operating in Marietta at the time.

${ }^{2}$ Mildred Throne, ed. The Civil War Diary of Cyrus F. Boyd, 125 [emphasis his].
} 
soldiers were successful in this endeavor, using a support system built of cultural concepts to manage their war experiences. As the previous chapter has shown, the number of men who escaped their experiences by committing suicide was very small. The low suicide rate most likely resulted from the effectiveness of soldiers' support systems.

When Union soldiers went to war they packed up the gear they would need to fight: clothing, supplies, weapons, ammunition, and reminders of home. Soldiers also unconsciously packed another set of gear, a "cultural toolbox" to support them through the ordeal they were about to face. These resources consisted of religious beliefs, established methods of facing and mourning death, ideas about courage and masculinity, and ties to the civilian world they had left behind. These tools helped soldiers survive the mental trauma of the Civil War and allowed them to understand and frame their wartime experiences within comfortable and recognizable limits. Scholars have looked at each of these concepts in previous works, but they have usually examined them individually. ${ }^{3}$ These concepts would not have been isolated for Civil War soldiers; instead, soldiers drew upon multiple concepts simultaneously, utilizing elements of each to match the situations in which they found themselves.

\footnotetext{
${ }^{3}$ For Culture of Death see: Drew Gilpin Faust, This Republic of Suffering: Death and the American Civil War (New York: Alfred A. Knopf, 2008); Mark S. Schantz, Awaiting the Heavenly Country: The Civil War and America's Culture of Death (Ithaca: Cornell University Press, 2008); Christianity: George C. Rable, God's Almost Chosen People: A Religious History of the American Civil War (Chapel Hill: The University of North Carolina Press, 2010); Steven E. Woodworth, While God is Marching On: The Religious World of Civil War Soldiers (Lawrence, KS: University Press of Kansas, 2001); Courage: Gerald F. Linderman, Embattled Courage: The Experience of Combat in the American Civil War (New York: The Free Press, 1987); Masculinity: Reid Mitchell, The Vacant Chair: The Northern Soldier Leaves Home (New York: Oxford University Press, 1993); Amy S. Greenberg, Manifest Manhood and the Antebellum American Empire (New York: Cambridge University Press, 2005); Lorien Foote, The Gentlemen and the Roughs: Manhood, Honor and Violence in the Union Army (New York: New York University Press, 2010); Also see James M. McPherson, For Cause and Comrades: Why Men Fought in the Civil War (New York:

Oxford University Press, 1997).
} 
This chapter seeks to analyze the ways soldiers used their cultural tools by examining the resources soldiers took with them to war and how they used them collectively to define and survive their wartime experiences. The war would test certain concepts, strengthen some and weaken others, but for most soldiers this "toolbox" assisted them through the war. This section will examine the "tools" themselves leading to an attempt in the conclusion to understand why they prevented a higher suicide rate.

\section{The "Cultural Toolbox" of the Union Soldier}

As soldiers experienced the "simmering down" process within the ranks and discarded unnecessary equipment, they could not afford to undergo the same process with their cultural resources. Facing new experiences and psychological transformations as they became soldiers, men turned to the world they left behind for methods of understanding and models of behavior. Men utilized their religious backgrounds, social methods of confronting and mourning death, ideas of masculinity and courage, and connections to family and friends at home. Religion, faith, and comforting ideas about the acceptance of death and the afterlife were crucial in allowing soldiers to cope with the very real possibility of their own deaths. These dynamics recurred throughout the letters and diaries examined in this research. The belief that God protected men in battle or that he ordained a man's time to die gave soldiers comfort and peace as they faced the test of battle, and soldiers were outspoken in their gratitude for surviving the ordeal. Men remembered how they had seen death before the war, how their society had dealt with the dead, and how they had mourned; when they saw widespread death on the battlefields or in camp, they used those practices to handle the demise of their comrades. The idea of the "Good Death" also encompassed elements of religion and Christianity and provided 
additional ways to frame wartime death. Ideas of courage and masculinity, while appearing less often in the letters of soldiers, shaped how men behaved during the war, both on and off the battlefield. Many men were away from home for the first time and as they entered the new world of the military, they looked for familiar standards. Even though there were different definitions of proper behavior, these concepts gave men guidelines to follow. Finally, despite physical and experiential distance, soldiers remained connected to their families and communities back home, which not only provided comfort and support but also shaped their behavior in the army. This combination of ideals was perhaps more important than their weapons and military training, or ideological ideas touted by other historians; these concepts dictated how a soldier would act in and react to their military life.

Religion, Christianity in most cases, provided guidelines for proper behavior and faith helped sustain morale for many soldiers in their new situation of army life. In letters, a wide range of soldiers made references to God. These could be continued expressions of devotion throughout military service or simple declarations of gratitude or hope for protection when facing battle. Although complete numbers are not available, scholars have argued that devout Christians were the minority in Civil War armies. However, whether or not a man claimed to be religious, the Civil War soldier was a product of a time when religion was quickly changing and in the public eye. The American Revolution inspired changes in religious thought as denominations tried to adjust to the new national culture, but the focus on theology grew rapidly in the 1820 s. There were more divergent voices and challenges to traditional methods, and the Second Great Awakening brought about an increase in revivalism, evangelicalism, and a new 
level of participation in religious discourse. Through the sectional crisis theology remained part of the national dialogue, and religious antagonism grew fierce as both Union men and Confederates declared their nation to be the "true Christian republic worthy of divine assistance." For the soldiers there was plenty of encouragement for spiritual reflection in camp. Christian men who enlisted attempted to continue their religious dedication, gathering to sing hymns and attend prayer meetings, services, and Sunday school sessions conducted by chaplains. Organizations such as the American Bible Society, the American Tract Society, and the United States Christian Commission supplied soldiers with testaments and evangelical tracts warning against the dangers of swearing, drinking, and gambling. Faith in God provided soldiers with personal psychological support as well as institutional support of country and cause. ${ }^{4}$

Spiritual tracts also included messages of salvation important to men who now had to face daily the possibility of their own deaths. Devout soldiers who made their peace with God and relied on Him for strength felt prepared to face the challenges ahead. Many agreed that Christians made the best soldiers due to their calm and steady nature in battle; their fear was of God, not of man. Other soldiers, impressed by the peace of Christian soldiers on the battlefield and on the deathbed, and faced with the greater possibility of their own deaths, found in the war their chance to convert. "I am trying to live a better man than I was at home," wrote a soldier in the $114^{\text {th }}$ Ohio, "I see the

\footnotetext{
${ }^{4}$ Mark A. Noll, America's God: From Jonathan Edwards to Abraham Lincoln (New York: Oxford University Press, 2002): 292-294, 368-369; Daniel Walker Howe, What Hath God Wrought: The Transformation of America, 1815-1848 (Oxford University Press, 2007): 164-202, 285-327; David Rolfs, No Peace for the Wicked: Northern Protestant Soldiers and the American Civil War (Knoxville: The University of Tennessee Press, 2009): 4-5 (quote), 21; George C. Rable, God's Almost Chosen People: A Religious History of the American Civil War (Chapel Hill: The University of North Carolina Press, 2010): 127-129, 132-133; James M. McPherson, For Cause and Comrades, 63.
} 
necessity of living a Christian here where thy ar dropping all around you." ${ }^{\circ 5}$ The horrific nature of battle encouraged prayer and an increased interest or renewed commitment to God. Writing after surviving the Battle of Cold Harbor, a member of the $4^{\text {th }}$ Delaware wrote: "In that dreadful place I resolved to forsake my evil ways and to serve god." Survival and close calls were particularly inspiring. "It was pretty close dogging for me to have a shell pass between my arm and side, and I think none but a Divine hand directed it," wrote Private Moses A. Parker of the $3^{\text {rd }}$ Vermont. ${ }^{6}$ “[T]hank God I am still alive, after many hair-breadth escapes," wrote infantryman William Collins. "One ball passed through my cap, another through the skirt of my coat—but not a scratch on my skin." ${ }^{7}$ Religious revivals swept the armies beginning in 1862 and continued through the rest of the war. Of course, not every soldier was swept up in the movement and skepticism continued, along with the camp vices of gambling, drinking, swearing, and sexual immorality. For many soldiers, however, faith provided them consolation, understanding, and the ability to overcome the natural fear of death. ${ }^{8}$

Christian soldiers placed great weight on God's will, the belief in Providence and divine sovereignty that resulted from Protestantism, Puritanism, and the Great Awakening. Lewis O. Saum states that providence, the view that God directly or indirectly controlled all things, was the most pervasive and fundamental theme in preCivil War writings. The war itself, and all of the death and destruction that came with it, was perceived to be part of a larger plan and a higher purpose. Soldiers went into battle

\footnotetext{
${ }^{5}$ James M. McPherson, For Cause and Comrades, 64.

${ }^{6}$ Steven E. Woodworth, While God is Marching On: The Religious World of Civil War Soldiers (Lawrence, KS: University Press of Kansas, 2001): 193.

${ }^{7}$ William H. Collins to wife, July 23, 1861. SoldierStudies.org, accessed November 29, 2011.

${ }^{8}$ George C. Rable, God's Almost Chosen People, 8-9, 132-133, 139-144, 162; Steven E. Woodworth, While God is Marching On, 194-195, 207-208, 215-216.
} 
believing that God's will would be evident in the outcome of the contest and the casualties; this provided a kind of relief to soldiers who believed that their actions would not result in their demise. ${ }^{9}$ Shirking would not protect them and going forward into danger would not harm them because the ultimate decision of life and death lay with God. The devout Henry Kellogg wrote "Trust in God he is good \& will do right."10 Even the belief in Providence and God's Will did not stop soldiers from turning seriously to prayer before battle, searching for strength and a reassurance of faith. "To his care I commit myself, he doeth all things well," Kellogg wrote several days later, "If it be thy will O God! spare me to support and cheer my wife and boy and comfort my aged parents, but if thou has ordained otherwise . . help all to say thy will be done." 11 Praying before and even during battle, some soldiers found a sense of peace and forgot the fear of death. "I feel very calm," wrote Elisha Hunt Rhodes in early May 1864, just before the campaign began, "trusting in God that his protecting care will be over me. While I do not feel that I am more safe than others, yet I have a firm reliance upon my Heavenly Father and am willing to leave all to him." This reliance on heavenly protection gave some soldiers the strength to step into the world of battle. ${ }^{12}$

God's support, soldiers believed, also extended to the Union cause as well, an idea promoted by military authorities through days of thanksgiving and prayer. Meant to continue God's favor, days of thanksgiving expressed joy in success and days of prayer followed failure. God's support and the belief that putting down a rebellion that was

\footnotetext{
${ }^{9}$ George C. Rable, God's Almost Chosen People, 1-2, 9; Lewis O. Saum, The Popular Mood of Pre-Civil War America (Westport, CT: Greenwood Press, 1980): 3; David Rolfs, No Peace for the Wicked, 106-108.

${ }^{10}$ Henry C. Kellogg to wife, May 6, 1863. SoldierStudies.org, accessed November 19, 2011.

${ }^{11}$ Michael R. Cunningham, "Follow me to victory or death": The diaries and letter of Captain Henry Martin Kellogg, 33 ${ }^{\text {rd }}$ Illinois Volunteer Infantry (1993): 33.

${ }^{12}$ George C. Rable, God's Almost Chosen People, 160-161; Steven E. Woodworth, While God is Marching On, 238 (quote).
} 
wicked and wrong was a just cause spurred some soldiers to continue fighting, and they did not want anything to jeopardize that favor. ${ }^{13}$ For example, fighting on the Sabbath concerned some soldiers. "I hope our army will not attack the enemy to-morrow," wrote Cyrus F. Boyd during the advance on Corinth, Mississippi, "as it is Sunday and our men seem to have a dread of going into battle on that day unless it is defence [sic]." These wary soldiers had good cause to feel that way: "The terrible Sunday at Pittsburgh [Shiloh] is pointed to and the reason given that the enemy was defeated because they commenced the fight on that day." ${ }^{\prime 14}$ Reflecting in 1865 on orders to fight on Sunday, June 14, 1863, William Jones echoed this protest: "Public attention had already been several times called to the fact that those who made the attack on that day [Sunday], were almost always unsuccessful, and in this case it seemed so unnecessary." Jones was not surprised that such decisions created dissent among the ranks, for almost every man had been taught from an early age to revere the Sabbath. But they must go forward, he concluded, for "it is the soldier's duty to obey implicitly and faithfully." 15

A sense of duty was key, and in some cases the relationship between God and country became so close that they almost meshed together. Civic religion emphasized national virtue, national purpose, and national destiny, and boasted of a strong relationship with God. Soldiers were willing to put duty to country before duty to family because of their devotion to their nation as a Christian republic. Americans, George Rable argues, believed they were God's chosen people who were carrying out His mission. Some soldiers even believed that by fighting and dying for the cause of their

\footnotetext{
${ }^{13}$ Steven E. Woodworth, While God is Marching On, 99-100.

${ }_{15}^{14}$ Mildred Throne, ed., The Civil War Diary of Cyrus F. Boyd, 47.

${ }^{15}$ William E. Jones, The Military history of the One Hundred and Sixty-first New York Volunteers, Infantry, from August $15^{\text {th }}, 1862$ to October 17, 1865 (1865). Army Heritage and Education Center, Carlisle, PA. U.S. Army Military History Research Collection.
} 
country, they would be guaranteed admission into heaven, bypassing the traditional Christian path of obtaining salvation through faith in Jesus Christ. ${ }^{16}$

The most fervent expressions of religious faith were made in gratitude for surviving a battle. Soldiers who believed in God's Will and Providence knew that it was He who had spared them in whatever engagement they had just survived. "Our good father led me safe through," wrote a soldier fighting near Mobile, Alabama, "\& know that it was through his kind providence that I was spared." ${ }^{17}$ The language varied, from a simple "[t]hrough the protection of the Almighty I have come off safe" after the Battle of Antietam to the more flowery "He who numbers the very hairs of our head and notes even the fall of the sparrow shielded me in the hour when bullets rained like hail around me," but the message was the same. ${ }^{18}$ Soldiers believed that God's protection kept them safe. "Any man who escaped with his life from that field [Gettysburg] although badly wounded may consider himself fortunate and preserved by some power above human."19 Even outside the immediate effects of battle soldiers praised God for their survival. Reflecting on the anniversary of one year in the service, Cyrus F. Boyd thanked God for his preservation and for both the enjoyments and hardships he had faced during that time. $^{20}$

\footnotetext{
${ }^{16}$ Steven E. Woodworth, While God is Marching On, 105-107; George C. Rable, God's Almost Chosen People, 3; David Rolfs, No Peace for the Wicked, 46-53.

${ }^{17}$ Joseph Prutzman to wife and children, May 23, 1865. SoldierStudies.org, accessed November 12, 2011.

${ }^{18}$ William Gilfillan Gavin, Infantryman Pettit: The Civil War Letters of Corporal Frederick Pettit, Late of Company C, 100 th Pennsylvania Veteran Volunteer Infantry Regiment "The Roundheads," 1862-1864 (Shippensburg, PA: White Mane Publishing Company, Inc., 1990): 14; Steven E. Woodworth, While God is Marching On, 193.

${ }^{19}$ J. Henry Blakeman, July 21, 1863. SoldierStudies.org, accessed November 29, 2011. The author was writing from Jarvis Hosptial in Baltimore, thus the comment about being thankful "although badly wounded".

${ }^{20}$ Mildred Throne, ed., The Civil War Diary of Cyrus F. Boyd, 80.
} 
With each sigh of relief and prayer of gratitude, however, soldiers knew that death could still be their fate in the next battle. Religion played a large role in their efforts to cope with the widespread death of war, but soldiers also carried other cultural understandings of death into the war in order to make sense of the casualties they saw. Mark Schantz argues that nineteenth-century America was a "death-embracing" society in which cultural scripts determined how people behaved on their deathbed and how they imagined death and the afterlife. Similarly, Drew Faust argues that the experience of death was a unifying experience for the American nation. Lewis Saum saw antebellum America as a culture focused on death simply because that was the reality of life. Mortality rates produced a constant discourse on the subject, a steady consciousness of the possibility of death led to fatalism and caution, and the lack of professional services for handling the dead and dying resulted in a widespread intimacy with the dead. The experiences of the antebellum age and the ways Americans engaged with death before the Civil War certainly had an impact on experiencing death during the war. To say, as Shantz does, that the "very pervasiveness of death in antebellum America trained up an entire generation to see it not as something to be avoided, but as the inevitable destiny of humanity"- thus making the Civil War generation more willing to accept war and death on the battlefield —may be going a bit too far, but this grounding certainly provided soldiers with a way to frame their wartime experiences. ${ }^{21}$

In addition to experiencing death within one's circle of family and friends, Shantz argues that antebellum Americans also encountered death in daily life through literature, art, cemeteries, and ideas of heaven. For example, poetry in the 1840s and 1850s

\footnotetext{
${ }^{21}$ Mark S. Schantz, Awaiting the Heavenly Country, 2-4, 8-10, 13-15; Drew Gilpin Faust, This Republic of Suffering, xii-xiv; Lewis O. Saum, The Popular Mood, 83, 86-90; Lewis O. Saum, "Death in the Popular Mind of Pre-Civil War America," American Quarterly 26, no. 5 (December 1974): 479-481.
} 
valorized death, especially massacres and slaughters, and the Greek revival re-introduced elements of martial tradition and heroic death. The concept of "heroic death" claimed that it was glorious for young men to die in battle, thus cheating the aging process. These brave young men would then be memorialized for eternity in the rise of the rural cemetery as places where the dead could be commemorated; their service would be remembered by the nation long after they were gone. The Mexican War was the first conflict wrapped up in these ideas and it made Americans deal with battlefield deaths far from home. In response, they wrapped the deaths of Mexican War soldiers in heroism and stylized last words and actions, bringing together a country-wide community to mourn. $^{22}$

The perfect last moments of a hero's life exemplified resignation and acceptance mixed with Christian piety and faith, and these ideas carried over to the Civil War. Part of this acceptance of death stemmed from emerging images of the afterlife. Preparing for an April 2 assault on Petersburg in the last year of the war, a soldier of the $86^{\text {th }}$ New York wrote: "Jesus owns me, O, how sweet to feel that if we fall on the field of strife, we only fall to rise to higher and more perfect bliss than this world can give. My object is to live for heaven." 23 A new, "modern" heaven was a perfected and more beautiful version of the life they knew, in which resurrected people would be reborn in perfected bodies, reunited with family and friends. The most important element of this vision was the fact that people would recognize each other when reunited in heaven; even though soldiers died away from home without their family, they would still see each other again after death. "May we meet again on earth," Captain Henry Kellogg wrote home, one of

\footnotetext{
${ }^{22}$ Mark S. Schantz, Awaiting the Heavenly Country, 8-9, 19, 26-30, 73, 82-87, 92, 119.

${ }^{23}$ Steven E. Woodworth, While God is Marching On, 254.
} 
several times he mentioned heavenly reunion, "but above all may we meet in heaven our home never more to part." 24 The image of heavenly reunion was a comfort to both soldiers and families, and lessened the fear of death for those who had to face it daily. ${ }^{25}$

The second part of accepting death concerned the prevalent idea of the "good death" in American culture. The idea of the "good death" was central to Christian and American life, but it owed its roots back to the Ars Moriendi of fifteenth century Europe. During that period Europe was recovering from millions of deaths caused by the bubonic plague and warfare at the same time interior and exterior forces challenged ecclesiastical authority. Social rites and ceremonies preserve the values of a society; the Ars Moriendi emerged to uphold the Church's values in the midst of chaos. Two fifteenth century texts, the Tractatus, or Speculum, artis bene moreiendi and the Ars Moriendi were the beginning of the literary tradition of "dying well" (the Ars Moriendi was translated into English in a volume entitled the Crafte of Dying); this literary tradition developed into a social method of handling the death process. The Ars Moriendi explained the importance of learning the art of dying and alleviated the natural fear of death, outlined the temptations the dying person would face and the best ways to combat them, and directed bystanders how to help the dying man prepare himself. Included were interrogations to ask the dying person to establish their faith, prayers to be said by the dying person and prayers to be said over the person by those around them. In the whole process the dying person was expected to imitate Christ as much as possible, suffering their death

\footnotetext{
${ }^{24}$ Michael R. Cunningham, "Follow me to victory or death," 7.

${ }^{25}$ Mark S. Schantz, Awaiting the Heavenly Country, 19, 30-31, 38, 40, 60-62, 67; Drew Gilpin Faust, This Republic of Suffering, 180.
} 
"patiently, conforming and committing fully his will to God's will and to God's disposition alone ..." in order to attain the "good death."26

The tradition of the Ars Moriendi continued to be central in Europe through the next few centuries and preparation for death was a necessity of life as well as a part of religious consciousness. Both a "holy life and happy death" were upheld as the exemplary Christian way and family and friends gathered around the deathbed to witness the end of a life in the same way women gathered in a birthroom to witness the beginning of one. These witnesses watched the dying for signs of fortitude and grace and recorded words and silences to search for their significance. Quiet, calm deaths and confessions of faith were part of a "good death" and these deathbed scenes gave the survivors solace. A sudden death or death during sleep did not allow for such witnesses, but was interpreted by many as God taking the soul directly to its reward and did not necessarily signify a "bad death."27

Transferred to America, by the nineteenth century the cultural practices of the "good death" had been separated from their religious roots and were part of respectable, middle-class behavior. Literary death narratives in the antebellum years spanned all genders, ages, and races, but continually highlighted acceptance, submission, and embracing death. Accepting death without question (including mass death and violent death) was part of accepting providence. By the time of the Civil War Americans were “so well armed with models of 'good deaths' that death itself was made to seem

\footnotetext{
${ }^{26}$ Nancy Lee Beaty, The Craft of Dying: A Study in the Literary Tradition of the Ars Moriendi in England (New Haven: Yale University Press, 1970): 1-4, 7-8, 10-33, 38-45, 49; Frances M. M. Comper, ed., The Books of the Craft of Dying and Other Early English Tracts Concerning Death, Taken from Manuscripts and Printed in the British Museum and Bodleian Libraries, Now First Done into Modern Spelling and Edited by Frances M. M. Comper, with a Preface by the Rev. George Congreve, S. S. J. E. (New York: Longmans, Green, and Co., 1917): 6-7; Drew Gilpin Faust, This Republic of Suffering, 6.

${ }^{27}$ David Cressy, Birth, Marriage, and Death: Ritual, Religion, and the Life-Cycle in Tudor and Stuart England (New York: Oxford University Press, 1997): 389-392.
} 
instructive, redemptive, and even glorious." A proper death was one that was witnessed, not only to provide comfort for the departing, but to provide inspiration to those witnessing a proper display of behavior. This meant that gathering family and friends around the deathbed was a key ingredient of dying; an unattended death was feared. Civil War soldiers heeded the instructive nature of the "good death." As Faust writes, "Death in war does not simply happen; it requires action and agents. It must . . be inflicted," which was the purpose of millions of soldiers during the war. "But," she continues, "death also usually required participation and response; it must be experienced and handled. It is work to die, to know how to approach and endure life's last moments." Soldiers needed to be ready and willing to die and they turned to their culture to direct them as they faced death. ${ }^{28}$

The Civil War, however, shook the cultural foundations of “dying well." War presented a challenge not only in the unprecedented and unexpected number of casualties created by a large-scale conflict with changing military weapons and transportation methods, but also in the violation of ideas about who should die and when, where, and how. Infant mortality and deaths of the elderly were expected and the ill and infirm knew the chances of their death; however, young and healthy men were taken in war, often instantly and without warning. Men were dying on the field of battle, far away from home and family, and often unattended, without the witnesses usually present in a "good death." Americans tried to construct "good deaths" in the difficult environment of war, trying to maintain the values they held before the war to get them through what they were experiencing. Soldiers utilized the new technology of photography and carried pictures

\footnotetext{
${ }^{28}$ Drew Gilpin Faust, This Republic of Suffering, xviii (quote), 5-7; Mark S. Schantz, Awaiting the Heavenly Country, 18, 36; Lewis O. Saum, The Popular Mood, 94-95.
} 
of loved ones with them on campaign; dead soldiers were sometimes found with these photos in their hands, surrogates for the family members who should have witnessed their last moments. ${ }^{29}$

Letters became an important way to connect families back home with the deaths of their loved ones, and they were the medium which most reflected the ideas soldiers had about the "good death." Comrades wrote to families about the demise of friends to provide details of their deaths. Sometimes, soldiers wrote home themselves if they were sick or wounded, occasionally even detailing premonitions of their own deaths. The writers tried to give solace to family members by framing the deaths in the familiar terms of the "good death," giving details to make family members "witnesses" to the event, reporting last words and actions, and speaking of good morals or religious values. ${ }^{30}$ When Captain Henry Martin Kellogg of the $33^{\text {rd }}$ Illinois Infantry was killed May 20, 1863 in battle around Vicksburg, his first lieutenant, Edward J. Lewis, wrote a letter reporting the death to Kellogg's wife:

...your noble husband is no more, he died the death of a brave man on the $20^{\text {th }}$ while leading his company, sword in hand, in an important advance to a close position under the fire of the enemies' works. The fatal blow from a piece of shell in the head was at least merciful, in so far as that he died quietly and without suffering. His comrades were especially around him, but he never spoke after the shot. We have made every effort, by his special request before his fall, to send his body to you; but as no boats are allowed to assault the river at present, we have been compelled to postpone this purpose for the present. We design to fulfill it at the earliest providable time. ${ }^{31}$

Lewis failed only to provide commentary on Kellogg's moral and religious character in following the model of "good death" narratives. He provided Mrs. Kellogg with details

\footnotetext{
${ }^{29}$ Drew Gilpin Faust, This Republic of Suffering, xii, 3-4, 11-12, 30-31. Amos Humiston of the $154^{\text {th }}$ New York is perhaps the most famous instance of a photograph found on the person of a dead soldier. After his death at Gettysburg on July 1, 1863, the ambrotype of three children found clutched in his hand eventually helped identify his remains and ensure a proper burial.

${ }^{30}$ Drew Gilpin Faust, This Republic of Suffering, 14-19.

${ }^{31}$ Michael R. Cunningham, "Follow me to victory or death," 1 (first page of letters section).
} 
of the mortal injury, assured her that her husband was surrounded by comrades at the time, and reported on final words and actions (in this case, none). Lewis also framed Kellogg as dying a brave death and gave his death consequence and meaning by telling her that it occurred during an important advance.

Christianity did factor into the letter sent to Frederick Pettit's family by his captain after he was killed by a sharpshooter in the trenches at Petersburg. Beginning as the Kellogg letter did, with "your noble son is no more," Captain Critchlow detailed the circumstances of Pettit's death, then assured the family that "he died as he lived, a devoted and exemplary Christian and I trust and believe your loss is his eternal gain."32 According to the ideal of the "good death" a believer prepared to die and welcomed the release from the world. As with the tradition of the Ars Moriendi, being conscious, prepared, and willing to die was important for the Civil War soldier. On the day before he died, Henry Kellogg wrote that "I suppose if we fight today my God must give me strength and success and prepare for death those who must die." ${ }^{, 33}$ Surrounded by the suddenness of death during war, never knowing when one might be struck down by bullet, shell, or disease, soldiers were encouraged to prepare themselves. The possibility of dying alone frightened them, but the fear of dying unprepared and without hope of salvation was worse for some men. ${ }^{34}$

Those who refused to prepare, who refused to repent of sins or died "unchristian," were considered "bad deaths," as were those who were executed for crimes instead of dying on the battlefield. Dying on the battlefield, or dying well off the battlefield, was

\footnotetext{
${ }^{32}$ William Gilfillan Gavin, Infantryman Pettit, 166.

${ }^{33}$ Michael R. Cunningham, "Follow me to victory or death,” 35.

${ }^{34}$ Drew Gilpin Faust, This Republic of Suffering, 17-19, 30-31; George C. Rable, God's Almost Chosen People, 166-169.
} 
important to soldiers, encompassing the ideas of "death before dishonor" and the "honorable death" or "honorable wound" received in combat. ${ }^{35}$ For some soldiers, the suicides of comrades were far from honorable deaths. Writing after learning of the suicide of Henry Johnson, Albert O'Connell Marshall wrote, "With a big war on hand and his command going to the front, it would seem that a soldier would know that he could have lots of good chances of being killed and to die in an honorable and useful way, and that he need not commit suicide." ${ }^{36}$ Similarly, John W. Jaques called the suicide of Joseph Fassbind "deplorable" and Charles Wright Wills labeled the suicide of a fellow soldier an act of "imprudence." ${ }^{37}$ Negative sentiments were not universal, however; some commentators expressed sadness or sympathy toward the suicide, chose to simply state the facts of the case, or used the language of insanity as explanation. Most soldiers remained silent on the suicides of comrades; for example, Nelson Chapin wrote to his wife stating "I have nothing you will call news to write you" only five days after the suicide in his regiment of Samuel Lindsay. ${ }^{38}$

Gerald Linderman argues that the set of values soldiers brought into the military centered on courage and, its opposite, the fear of cowardice. "In fact," wrote William Wheeler, "so all-important are the virtues of courage and firmness out here, that one has a

\footnotetext{
${ }^{35}$ Drew Gilpin Faust, This Republic of Suffering, 26-28; Gerald F. Linderman, Embattled Courage, 12, 32.

${ }^{36}$ Albert O'Connell Marshall, "Memoir of Albert O'Connell Marshall," 30-31.

${ }^{37}$ John W. Jaques, Three Years' Campaign of the Ninth, N.Y.S.M., During the Southern Rebellion (New York: Hilton \& Co., Publishers, 1865): 39; Charles Wright Wills, "Diary of Charles Wright Wills, June, 1861," in Army Life of an Illinois Soldier: Including a Day by Day Record of Sherman's March to the Sea: Letters and Diary of the Late Charles Wright Wills, Private and Sergeant $8^{\text {th }}$ Illinois Infantry, Lieutenant and Battalion Adjutant $7^{\text {th }}$ Illinois Cavalry, Captain, Major and Lieutenant Colonel 103 ${ }^{\text {rd }}$ Illinois Infantry, Compiled by Mary E. Kellogg (Globe Print Co., 1906): 21, accessed February 3, 2011, American Civil War Diaries and Letters.

${ }^{38}$ Nelson Chapin letters, letter of October 4, 1863. Army Heritage and Education Center, Carlisle, PA. Civil War Times Illustrated Collection, Box 5. Interestingly, another comrade of Chapin and Lindsay, Stephen Tuppet Andrews, commented on Lindsay's suicide in two separate letters, calling is a "sad affair," a "sad occurrence," and using the language of insanity, from Sally Andrews Earnest, ed., Letters of Stephen Tuppet, 96-97.
} 
tendency to forget that any other virtues are worth practicing." 39 Wartime evidence suggests that courage was not necessarily in the center of the Civil War soldier's toolbox, as Linderman claims. Linderman's reliance on post-war memoirs may explain his argument; courage may have factored more prominently in reminiscences far after the death and destruction had settled. Still, courage certainly assisted men in multiple ways during their military service. It helped maintain good discipline on the battlefield and steeled men against reacting to the sights of death and destruction all around them. William Phillips admitted that he did not like battle but he went in when ordered because his "stock in the trade was about an ounce of courage and the balance in pride and honor. With that, I manage to put on a bold face." ${ }^{40}$ Courage also ensured success, for they believed that the brave would live and the cowardly would die, and if the brave did die then they died well. In defeat, soldiers could still cheer their performance if they had fought to the best of their abilities. ${ }^{41}$

Soldiers strived to prove their courage through actions in which they betrayed no sense of fear, in combat, in camp, and in the hospital. "Every man marched up to the breastworks as cool and determined as if they were made of steel" wrote an infantryman in 1863 , describing a proper battlefield display. ${ }^{42}$ Resisting reactions of fear could truly be a struggle for some soldiers facing battle. Artilleryman William Christie admitted to his father that, even though he had stood firm on the field of battle before, an engagement before Vicksburg in late May 1863 made him feel so nervous he wanted to run away. Despite being "desperately afraid" he remained in his post, thinking about his duty and

\footnotetext{
${ }^{39}$ William Wheeler, Letters of William Wheeler of the Class of 1855, Y.C. (1875): 366 (letter of November 25, 1862). American Civil War Letters and Diaries, accessed December 1, 2011.

${ }^{40}$ William Beynon Phillips to Annie, July 4, 1864. SoldierStudies.org, accessed November 11, 2011.

${ }^{41}$ Gerald F. Linderman, Embattled Courage, 2, 43-45, 61-65.

${ }^{42}$ Delavan Bates to father, November 8, 1863. SoldierStudies.org, accessed December 1, 2011.
} 
trusting in God, but, he told his father, "could you have seen my inner self, you would have seen a very strange trial of strength."43 These actions proved one's manhood and masculinity — Christie said that his actions in the very battle in which he had his inner struggle of courage encouraged comrades to consider him "good coin anywhere"—or jeopardized one's reputation if they failed the test. ${ }^{44}$

While soldiers wrote about courage, bravery, and valor, they more often spoke of its opposite, cowardice. Civil War soldiers were afraid of battle, and as they passed their first tests of fire they began to admit it more openly. "The man who does not dread to die or to be mutilated is a lunatic," wrote veteran John W. De Forest after the war. But, despite this fear soldiers still went forward because they were more afraid of cowardice than of death. After the Battle of the Wilderness in May 1864, in which his regiment had lost eighty men killed and 254 wounded over two days, Wilbur Fisk of the $2^{\text {nd }}$ Vermont wrote, "I am sure that if I had acted just as I felt I should have gone in the opposite direction . . . but I wouldn't act the coward." Those who did "act the coward" were labeled skulkers and faced shame and derision from fellow comrades and in some cases faced formal punishment that could severely damage one's reputation. "The others shame those few so much," reported a New Hampshire man, "that they must of necessity come up to scratch or be in disgrace." Not only were men in danger of censure in the army, but reports of cowardice swiftly made it home in letters and newspaper reports; in order to keep his own good name and that of his family, a soldier had to avoid the label of coward. In some cases, men went so far as to go into battle even though they were wounded or ill, and men in behind-the-lines positions pulled strings to be placed in

\footnotetext{
${ }^{43}$ William G. Christie to father, May 31, 1863. SoldierStudies.org, accessed November 29, 2011.

${ }^{44}$ Gerald F. Linderman, Embattled Courage, 20-23, 27.
} 
combat. A lieutenant colonel who broke down in June 1864 returned to his regiment after only a week in the hospital because "those who keep up are full of ugly feelings toward those who fall [behind], intimating in every way possible that it is cowardice that is the cause." By returning to the regiment and facing the same dangers as his men, he could avoid those charges. Courage as an ideal certainly inspired some men to face the test of battle, but more often it was the fear of shame resulting from a charge of cowardice that kept men in line. ${ }^{45}$

After Wilbur Fisk declared that he would not "act the coward" at the Wilderness despite his fear, he wrote that, "I clenched my musket and pushed ahead determined to die if I must, in my place and like a man." Notions of courage and bravery were interwoven with ideas of manhood and masculinity; a soldier who did his duty and fought well was a man, a coward was not. "I do most earnestly hope that I may be enabled to meet my duties like a man when the breath of battles blows around me," wrote a corporal in the $64^{\text {th }}$ Ohio, "I do hope I may be brave and true for of all names most terrible and to be dreaded is coward."46 Being brave and avoiding the shame of cowardice were the same as meeting the "duties" of manhood. War was a prime opportunity to prove one's manhood by showing proper displays of behavior, but the Civil War was a time "when the motto, 'Death, or an honorable life,' [tried] more sharply the manhood of him who adopts it" than previously. ${ }^{47}$ The environment of war made fulfilling these duties more

\footnotetext{
${ }^{45}$ James M. McPherson, For Cause and Comrades, 5, 37, $77-82$ (quotes); Gerald F. Linderman, Embattled Courage, 56-57.

${ }^{46}$ James M. McPherson, For Cause and Comrades, 82.

${ }^{47}$ James Kendall Hosmer, The Color-Guard: Being a Corporal's Notes of Military Service in the Nineteenth Army Corps (Boston: Walker Wise and Co., 1864): 83. American Civil War Letters and Diaries, accessed December 1, 2011.
} 
difficult, but soldiers looked to prove themselves within their personal definitions of manhood.

For soldiers in their late-teens and early-twenties, the Civil War was literally their “coming of age." Leaving home for war, many for the first time, these men explored new found freedom while trying to uphold expectations of masculinity, a boundary which itself was shifting. Americans in the middle of the nineteenth century experienced a shift in the definition of masculinity. There was no single conception of manhood going into the war years and men practiced their masculinity in a variety of ways, including boxing, melodrama and minstrelsy, self-restraint and discipline, membership in organizations or men's clubs, dueling, expressions of fraternal love (primarily within abolitionism), competition, and politics. These expressions were not necessarily divided by class, but Amy Greenberg argues that there were two main types that emerged. Restrained manhood put priority in family, faith, and business success, believed in domesticity as the moral center of the world, and refrained from blood sports and excessive drinking. This manhood was derived from being morally upright, reliable, and brave. Martial manhood, on the other hand, rejected these moral standards and believed their masculinity was defined by strength, aggressiveness, and violence. ${ }^{48}$

Of course, not all men fit squarely within these two categories, as Greenberg concedes and Lorien Foote argues. Foote argues that artificial categories should not be created to fit men into and that each man's individual values shaped his definition of masculinity. Her work practically mirrors Greenberg's argument, however, as she divides Union soldiers into the categories of "gentleman" and "rough." Her version of

\footnotetext{
${ }^{48}$ Reid Mitchell, The Vacant Chair: The Northern Soldier Leaves Home (New York: Oxford University Press, 1993): 5-7; Amy S. Greenberg, Manifest Manhood and the Antebellum American Empire (New York: Cambridge University Press, 2005): 9-14.
} 
restrained manhood is the moral Union soldier who attended worship throughout his military service and tried to reform the camps of drinking, dancing, women, gambling, cursing, and other vices. Some of these men held themselves to standards of gentility: self-control, self-improvement, cleanliness, and etiquette. These men resisted yielding to the temptations of camp. Byron B. Wilson wrote, "I am just the same here as at home. I know one need not lose his manhood in becoming a soldier."49 Other soldiers ascribed to camaraderie defined by noise, unruly behavior, and physical prowess; these men would fit into Greenberg's conception of the martial man. Neither the military nor all men fully supported either idea of "proper" behavior. Army regulations supported the moral conduct exhibited by the "gentlemen," but there was no set definition of these behaviors. On the other hand, the rowdy behavior of the "roughs" offended standards of army discipline, but violence was sometimes acceptable in matters of honor. Marylander John Rastall had to arrest five men who had forcefully cornered one of their lieutenants in a bar, but his solution to the situation was to call in his men and start a street fight. Called to confront "unhonorable" behavior, Rastall used similar behavior as his solution, illustrating how murky the lines of honor and manhood were. ${ }^{50}$ Both concepts were accepted, denied, and adapted by the army and its soldiers, and the men took elements of both to define their personal masculinity. With the shifting definitions of manhood in the nineteenth century, the most important thing was that others recognized and respected a man's conception of masculinity, their reputation for masculine self-restraint or

\footnotetext{
${ }^{49}$ Byron B. Wilson, Soldiers' Letters, from Camp, Battle-field and Prison (New York: Bunce \& Huntington, 1865): 99. American Civil War Letters and Diaries, accessed December 1, 2011.

${ }^{50}$ John E. Rastall to parents, May 20, 1864. SoldierStudies.org, accessed December 1, 2011.
} 
aggression, particularly the men in his company and regiment whom he interacted with closely. Only then could a man feel that he had proven himself. ${ }^{51}$

In addition to concepts of masculinity shaping soldiers' behavior, men also used cultural guidelines about masculinity to determine why they were fighting. Reid Mitchell, who stresses the importance of the more "restrained" masculinity as the definition of "true" masculinity, argues that simply volunteering to fight was a sign of manhood. A man's decision to become a soldier meant they accepted their responsibility to defend home and country and fight for one's immediate family, extended national family, ancestors and future generations. ${ }^{52}$ Duty to country certainly spurred some men to keep up the fight. "You spoke of my keeping up good courage," one soldier wrote, "in this when our country's and liberty is at stake, if we did not keep up good cheer I would not answer for the safety of our cause. ${ }^{, 53}$ Charles Lynch would have agreed when he wrote in June 1864, “[we] keep up courage very well as we endure these hardships, all for our country.",54

Fighting to defend one's home meant that connections to family and the civilian life left behind was important to Civil War soldiers, and their definitions of manhood. In one very real way the war was an extension of the home community; companies and regiments were often recruited within the same social organizations or towns, meaning many soldiers knew each other from civilian life. Those who remained at home could encourage enlistment or put pressure on soldiers to do their duty well; at the same time they worried that camp life would corrupt their loved ones. The military took these men

\footnotetext{
${ }^{51}$ Lorien Foote, The Gentlemen and The Roughs, 4, 19-28, 51, 55, 57, 67, 77, 89.

${ }^{52}$ Reid Mitchell, The Vacant Chair, 11-15.

${ }^{53}$ Justus G. Matteson to Mary, December 3, 1863. SoldierStudies.org, accessed November 11, 2011.

${ }^{54}$ Charles H. Lynch, diary entry for June 22, 1864. SoldierStudies.org, accessed November 11, 2011.
} 
from their normal environment in which Victorian culture could dictate their behavior. Women were the center of the virtuous household and central to good order; without a feminizing presence in the army men became rougher and more tempted by vice. There was a distrust of the professionalized military and a fear that soldiering would turn men into rough, harsh killers. Family members urged men going off to war to remain pure and reject moral degeneration, and initially soldiers saw the war as an extension of their home life where the same values and behavior applied. Manhood, however, could not be defined without its opposite, womanhood. The fact that there were no women in a soldier's daily life, and that the southern women they encountered often did not match their concept of virtuous womanhood, meant there was no example for men to ground their masculinity in. Soldiers found themselves straying into the boundaries of the female domain by taking on the tasks of washing, cooking, cleaning, mending, and providing nurture and care to wounded or sick comrades. The environment of a purely masculine world meant that soldiers had to fill the female void, placing further strain on their ability to define and prove their own masculinity. ${ }^{55}$

These men were anxious to maintain connections with family at home to help them bear the hardships of their military life and resist the new temptations they encountered. James McPherson claims, "without a firm base of support in the homes and communities from which these citizen soldiers came, their morale would have crumbled." ${ }^{, 56}$ Mail call was the biggest highlight of the day, when soldiers received news from loved ones at home. Communication between soldiers and civilians was an important support system; soldiers often wrote about how thinking about home and

\footnotetext{
${ }^{55}$ Reid Mitchell, The Vacant Chair, 11-15, 21-24, 72-87, 89-100; Gerald F. Linderman, Embattled Courage, 36, 73-78, 83-95; Earl J. Hess, The Union Soldier in Battle, 122-125, 154.

${ }^{56}$ James M. McPherson, For Cause and Comrades, 131.
} 
family sustained them through their experiences. When writing to his aunt and uncle, Homer A. Plimpton of the $39^{\text {th }}$ Illinois Infantry asked, "Did you know that often when undergoing some of the severe hardships \& exposed to the imminent dangers incident to a soldier's life we are many times encouraged by thoughts of our friends at homecheered by the thought that they may even now be thinking of us?" He added that "I sometimes think that our friends at home fail to appreciate the importance attached to this duty of writing often \& freely to the soldier."57 Battle was a hard experience, but it took more reassurance to stay in the army day after day. To stay in the ranks, soldiers looked for continual approval from home. ${ }^{58}$

Family members also used letters and newspaper reports to keep track of their loved ones, especially in terms of their behavior and morals. Soldiers monitored one another and reported successes and lapses back home; soldiers who planned to return to their communities after the war was over knew that they were being watched and, in most cases, tried to maintain respectable behavior. ${ }^{59}$ After newspaper correspondents charged his regiment with cowardice in July 1861 , a Captain in the $12^{\text {th }}$ New York Infantry wrote back in defense of his regiment's good name. He claimed that their retreat was ordered by their Colonel, and thus could not stain the reputation of the men in the eyes of others. $^{60}$

More importantly, thoughts of home sustained soldiers through the war. For O. W. Norton, the excitement of military life had passed by April 1862, causing him to look

\footnotetext{
${ }^{57}$ Homer A. Plimpton to uncle and aunt, September 16, 1864. SoldierStudies.org, accessed November 11, 2011.

${ }^{58}$ Eric T. Dean, Jr., Shook Over Hell, 92-93

${ }^{59}$ Reid Mitchell, The Vacant Chair, 24-31; Lorien Foote, The Gentlemen and the Roughs, 80.

${ }^{60}$ Augustus I. Root to The Daily Republican Advocate, July 23, 1861. SoldierStudies.org, accessed December 1, 2011.
} 
forward to the time he could settle down to farming and find a woman to marry, and William Beynon Phillips exclaimed, "[w] hat a blessing it would be . . to go around and about, to enjoy your society and caresses, without having to be disturbed by Rebel shot \& shell, to feel certain when I lay down to rest that I am safe from harm as far as lead and iron are concerned."61 As much as soldiers longed for the peaceful blessings of the civilian life they had left behind, those same blessings kept them fighting. "I can only think of home," wrote a man from Indiana, “[a]nd but for those at home I might feel less like serving my country." 62 Support from home kept soldiers going, not just as an ideal to which soldiers longed to return or the families that were waiting for them, but also as a reminder of what many of these men felt they were fighting for. Men frequently expressed delight on receiving letters, asked for or discussed news from home, begged for paper and stamps so they could keep up the correspondence, and expressed desires to be back with loved ones again once they completed their duty. Soldiers relied on these connections far more than grand ideas, revealed through language that expressed the need and longing for basic connections with loved ones.

The family was the prime social organization that defined expectations of manhood, and thus it became a commonly used metaphor, as well as a framework for structuring wartime relationships. The sectional crisis itself was portrayed as a family problem; the South was an errant child who needed to be punished and brought back into the fold. A July 1861 newspaper article stated, "I can think of but a single rebellion that will furnish any adequate parallel to the present rebellion of the cotton states of this country in 1861, and that is, the rebellion of the proud, luxurious, lascivious,

\footnotetext{
${ }^{61}$ O.W. Norton to "Sister L," April 21, 1862. SoldierStudies.org, accessed November 12, 2011; William Beynon Phillips to Annie, July 20, 1864. SoldierStudies.org, accessed November 12, 2011.

62 James M. McPherson, For Cause and Comrades, 131.
} 
unprincipled, murderous Absalom, against his noble, unsuspecting, too affectionate and over-indulgent father, David."63 Men described Abraham Lincoln, and more specifically their officers, as father figures who took care of them and were to be obeyed. In many cases, company officers were usually older men of the regiment's community who were in a "father-like" position before the war and had promised parents they would look after the "boys." Officers needed to show bravery, but more importantly they needed to look out for their men. Speaking of General Mott, Matthew Austin of the $5^{\text {th }}$ New Jersey wrote that Mott had "won the esteem of all who came in contact with him." The General had proven himself a brave man, Austin continued, but he was "brave, without being rash - knowing how to save his men from unnecessary danger or death — which required a cool head to judge of in the time of battle."64 Officers who commanded only for their own advancement, or to "retrieve lost 'reputation"” received little respect from the men they led. In addition, officers who did not lead by example, or worse showed cowardice, were reviled and those who enjoyed more comfort than their men were cast in a bad light. Enlisted men expected their officers to show the right balance of masculine bravery and feminine care. Beloved officers who commanded the respect of their troops on and off the field were often those who visited the sick and wounded in the hospital, made sure their men had the supplies and care they needed, and assisted with financial troubles. Officers understood their position and the power-structure of the camp; the colonel of the $54^{\text {th }}$ Ohio commented that men in his position were "compelled to be a father to a large family who call on him for every thing." More noted were the officers who shared the

\footnotetext{
${ }^{63}$ Harry Stout, Upon the Altar of the Nation: A Moral History of the American Civil War (New York: Viking, 2006): 42; This biblical story, interestingly enough, contains one of the few suicides detailed within the Bible. Absalom's advisor, Ahithophel, commits suicide after his counsel is rejected for that of another man, who happens to be working for David (2 Samuel 17:23).

${ }^{64}$ Matthew S. Austin to father, September 23, 1862. SoldierStudies.org, accessed December 1, 2011.
} 
burden of the march, marching with the men or allowing soldiers to ride their horse for periods of time, and who lived in the same conditions as the rest of the regiment; this garnered them respect from their troops that at times bordered on devotion. As the father of a military family, officers were expected to treat their soldiers with equality while maintaining their position of command and respect. ${ }^{65}$

If the officers were the patriarchs of the military family, a soldier's close companions and messmates were part of a brotherhood. Pride and honor in groups such as regiment, state, and nation were certainly motivators for soldiers, but the "primary" association fell with the small group men associated with in daily life. Soldiers created fictive families among their fellow enlisted men while they were away from their real family back home. This "band of brothers" was bonded through mutual dependence. "You would not believe that men could be so attached to each other," said a member of the $1^{\text {st }}$ Ohio Heavy Artillery, but "we are all like brothers." Not only did they support each other by sharing tents and company and cooking rations together, these men could also understand what each other felt because they were experiencing the same thing. The same trauma that could cause emotional or psychological damage also strengthened a soldier's connection within the unit because they all contributed to the same cause. The tight bonds of camaraderie built through marching, fighting, and camp life were a major factor in keeping men in the ranks. If one man shirked his duty or showed cowardice it might endanger the survival of the entire group; peer pressure among these small messes to avoid cowardice was heavy. The loss of self-respect and camaraderie caused by being ostracized from one's primary association group was incentive for soldiers to fight. "You

\footnotetext{
${ }^{65}$ James M. McPherson, For Cause and Comrades, 53-60 (quote); Reid Mitchell, The Vacant Chair, 115$119,127-132$.
} 
ask me if the thought of death does not alarm me. I will say I do not wish to die," admitted a New York soldier to his sister in 1864. "I myself am as big a coward as eny could be," he continued, "but give me the ball [bullet] before the coward when all my friends and companions are going forward." The strong bonds of comradeship not only supported soldiers physically and emotionally in camp, they also provided incentives and reinforcement on the field of battle. Standing side-by-side with their military family gave many men the strength to move forward on the battlefield. ${ }^{66}$

Relying on the support of fellow soldiers and officers, soldiers tried to recreate their civilian world within the environment of war. By creating "families" among their messmates soldiers formed bonds of mutual dependence and support they could lean on. Along with utilizing ideas of family to manage wartime experiences, soldiers clung to their civilian and societal identities by continuing to use concepts of religion, death and mourning, masculinity, and courage. The strength of this "toolbox" and the connections it maintained provide a possible explanation for the low suicide rate in the Union Army.

\footnotetext{
${ }^{66}$ Gerald F. Linderman, Embattled Courage, 234-236; Earl J. Hess, The Union Soldier in Battle, 111-122; James M. McPherson, For Cause and Comrades, 82-83, 85-87 (quote); Craig J. Bryan, et al, "Combat Experience," 1046-1047; Mark H. Dunkelman, Brothers One and All, 5-6, 10.
} 


\section{Conclusion: \\ The "Cultural Toolbox" and Suicide}

When entering the foreign, disorienting, and dangerous world of warfare, Civil War soldiers used the familiar aspects of their civilian life to deal with their experiences, unconsciously carrying a "cultural toolbox" to interpret the meanings of what they thought and did. Concepts of religion and the "good death," courage and masculinity, and ties to the civilian world dictated how soldiers would act in, react to, and survive the trials of war. Faith in heavenly protection and providential oversight gave men the courage to face battle, and the hope for a place in heaven eased their fear of death. Striving to follow the guidelines of the comfortable and familiar "good death" amidst the chaos of war gave soldiers a way to understand and frame the deaths of comrades and family members to give them meaning. In life, as in death, behavior and conduct were important to soldiers; here concepts of masculinity and courage shaped their behavior on and off the field of battle. Courage and, more specifically, the fear of cowardice spurred men to fight through fear in the hope of proving oneself a good soldier and a man. This good conduct was important not only to themselves, but to the families back home monitoring their loved ones. Continued connections to home inspired men to keep going until the day they were able to rejoin their families. Using their civilian families as models, soldiers built military families among their comrades and officers that acted as a primary support system and as arbiters of manhood during the war.

Civil War soldiers found themselves pulled in two directions. On the one side, they faced multiple challenges in entering the world of war. They left their homes and 
the lives they knew and faced a new world of poor conditions and hard combat. The sights, sounds, emotions, and responsibilities of soldiering placed a strain on these men, emotionally, physically and mentally. On the other hand, soldiers carried with them a support system of social and cultural norms and familial ties. Religion, mourning, masculinity, courage, and family provided modes of comprehension for men placed in unfamiliar circumstances. In addition, each of these elements provided connections to family or society that made soldiers continue to feel a sense of belonging. Soldiers felt the effects of both sides as they went through their military service, but the support system had to be stronger than or at least balance out the negative effects of war in order for soldiers to handle the experience well. When the hardships of soldiering began to overwhelm or break down a soldier's support system, the situation might arise where he would experience trauma or, at the most extreme, commit suicide.

While the combination of tools most likely varied between individual soldiers, they were just as important, if not more so, as physical needs in dictating a man's survival in the chaos of war. By transferring social norms and standards of behavior to their new life in the military, soldiers were able to rely on familiar concepts to manage their experiences. Adjusted and molded to fit the new situation, these tools still reflected the society they came from and provided a form of connection to the life these men left behind. As argued in Thomas Joiner's interpersonal-psychological theory of suicide, feeling connected is an important element in explaining why a person would not commit suicide; in his theory the potential for suicide increases with feelings of failed belongingness. It can be argued that most soldiers gained a certain level of acquired capability through witnessing and participating in an environment of extreme violence 
and wide-scale death. However, the other parts of Joiner's suicide equation were nonexistent for most Union soldiers.

Concrete connections were sustained with family and friends back home and built between comrades sharing the hardships of war. If, for some reason, a soldier experienced difficulty or a weakening in the familial bonds, they could look to the men around them for support, and if the brotherhood of arms failed a soldier looked back to family. For example, after catastrophic losses at Gettysburg William Charles wrote to his wife, "Since that Battle I have felt very lonesome \& if it was not for you \& those two little ones I would rather die than not you see all the Welsh boys are gone every one of them and I am left alone." ${ }^{67}$ Charles' bonds with his military family had weakened, but he still had his wife and children. Maintaining connections to one's civilian life were also sustained in more abstract forms; maintaining religious beliefs and relying on familiar social norms provided more subtle reminders of a larger community in which the soldier lived. The Union army was primarily one of volunteers who wanted to distinguish themselves from the professional soldier. By continually reasserting their position as civilians before soldiers, Union men reaffirmed their connections to their home society. Feeling close connections to individual family members, friends, and comrades, as well as broad connections to a wider society and military organization meant that soldiers had many places to turn in order to avoid feelings of failed belongingness.

Soldiers' connection and activity in the cause of the Union could explain the prevention of "perceived burdensomeness." As discussed previously, periods or positions of inactivity led to soldiers feeling useless. However, even during these periods

\footnotetext{
${ }^{67}$ Mark H. Dunkleman, Brothers One and All, 95.
} 
of inactivity (winter encampments or the time between battles, for example) soldiers could reassure themselves that they were still doing their duty by being with the army in the service of their country. Support and encouragement from wives, parents, and other family members prevented soldiers from feeling a burden on those left at home, mitigated further by the fact that most soldiers sent portions of their pay home to support those families. With a cause to fight for and the maintenance of multiple connections sustaining men in their military roles, soldiers could avoid two of the three elements in Joiner's theory_-failed belongingness and perceived burdensomeness. The trauma of warfare certainly affected the men who experienced it, but without those two pieces of the puzzle, the acquired capability created through war experience would not be enough to lead a soldier to suicide. Union soldiers had access to multiple resources which maintained their feelings of connection and usefulness; utilizing this support structure most likely explains why the suicide rate was relatively low in the Union army.

Suicide provides a focal point for the spectrum of reactions to war because it marks one extreme. By analyzing factors that influenced a soldier either negatively or positively along that spectrum, we can further understand their experiences fighting in the Civil War. By investigating suicides we learn how some men adjusted to specific traumas associated with battle, illness or injury, and time as a prisoner of war. Soldiers between the ages of twenty-six and thirty may have been more prone to trauma or the risk of suicide despite the expectation that younger men would be more resilient. Fighting with different branches of the military put soldiers into different levels of personal combat; infantrymen experienced the closest and most heated fighting and exhibited a 
larger suicide rate. We also see that the first year of enlistment was the most difficult, most likely due to the difficulties of transitioning from civilian to soldier.

By analyzing these cases through modern theories of suicide, particularly Thomas Joiner's interpersonal-psychological theory we learn how important it was to maintain feelings of connection to counter the heightened capability of self-harm attained by soldiers in violent situations. Soldiers preserved these connections by relying on concepts such as religion, mourning rituals, and standards of behavior which continually placed them in their wider society and reminded them of the civilian world to which they would eventually return. The connections a soldier maintained with family members and those they built with their fellow soldiers were even more tangible. Individual soldiers most likely found themselves at different points of the scale, but all were influenced by the convergence of the negative and positive factors analyzed here.

I find that soldiers relied on cultural elements more than ideological ones; they grounded their experiences and how they handled them in their civilian society. In the aftermath of the war soldiers could feel pride in the larger, positive outcomes of the war, themes of reunion, emancipation, and nationalism that were often touted at veterans reunions. However, away from the hype and sentiment of reunion, soldiers saw daily the impact of war on themselves, their families, and their community. For the individual soldier, the war was destructive, not productive. They were fundamentally changed by their experiences during the war and these alterations affected men's relationships with the people around them and even their own identity. In addition, soldiers who returned to home communities saw holes where comrades who did not return should have been. The 
impact on the individual soldier is the darker side of the Civil War, a war whose traditional narrative promotes the ideological triumph of unionism and freedom.

This understanding adds to the knowledge of wartime mental trauma, a subject that is receiving widespread attention in the modern age. By examining evidence of trauma in previous wars and the support systems that countered them, the current military may develop better programs and tools to assist soldiers and veterans with PostTraumatic Stress Disorder and other reactionary difficulties. The Civil War is not an isolated element in our history, it shapes and molds our perceptions and decisions as Americans even today. Studying the failure of Civil War soldiers to cope with their experiences in addition to the actions of those who succeeded, does not only lead us to more complex understandings of the Civil War. Examining the suicides of Union soldiers also tells us more about ourselves as human beings who are sometimes called to witness and experience different levels of trauma. The experience of a suicidal Union soldier is not relevant only to his time, but provides lessons to both soldiers and civilians today and in the future. 


\section{Appendix}

101 Soldier Cases Used for Analysis:

\begin{tabular}{|c|c|c|c|c|c|}
\hline Last Name & $\underline{\text { First }}$ & $\underline{\text { Regiment }}$ & $\underline{\text { Age }}$ & Enlistment Date & Death Date \\
\hline Abrams & Aaron & 2 NY Cav & 30 & December 12,1861 & March 15, 1863 \\
\hline Anderson & Alexander & $1 \mathrm{IL}$ Art & UNK & July 16,1861 & June 27,1862 \\
\hline Angelist & David & 7 CT Inf & UNK & September 7, 1861 & June 27,1863 \\
\hline Babcock & Lorenzo G. & 125 NY Inf & 26 & August 11, 1862 & May 6, 1864 \\
\hline Bailey & Andrew & 109 IL Inf & UNK & August 15,1862 & September 17,1862 \\
\hline Beckman & Heinrich & $138 \mathrm{IL}$ Inf & UNK & June 1,1864 & September 1, 1864 \\
\hline Bissell & Henry & $1 \mathrm{CACav}$ & UNK & August 12,1861 & June 16,1862 (or 17) \\
\hline Blum & Aaron & $82 \mathrm{NY}$ Inf & 36 & February 25,1864 & April 1, 1864 \\
\hline Boker & Antoine & $53 \mathrm{IL}$ Inf & UNK & January 25,1862 & May 7,1863 \\
\hline Bourke & Thomas & 4 CA Inf & UNK & May 7, 1862 & December 20, 1863 \\
\hline Bowman & William & 56 NY Inf & 35 & August 20, 1861 & September 1865 \\
\hline Bull & Lewis E. & 7 CT Inf & UNK & August 22, 1861 & October 20,1862 \\
\hline Busch & Carl & 3 NY Inf & 29 & June 2,1862 & November 14,1862 \\
\hline Carman & Sylvester & 4 NY Art & 21 & September 2, 1862 & July 1,1864 \\
\hline Congden & Martin & 2 NY MtRls & 28 & December 7, 1863 & March 9, 1864 \\
\hline Diatz & Casper & $15 \mathrm{NY}$ Art & 24 & March 1, 1864 & December 11,1864 \\
\hline Doring & August & 58 NY Inf & 16 & August 28, 1861 & April 2, 1865 \\
\hline Ellis & Thomas & 152 NY Inf & 25 & September 2, 1862 & May 16,1863 \\
\hline Ellison & Oliver & $10 \mathrm{IL}$ Cav & UNK & October 28,1861 & May 18,1863 \\
\hline Fassbind & Joseph & 83 NY Inf & 23 & May 27, 1861 & August 19,1861 \\
\hline Forsells & Jonas & $75 \mathrm{IL}$ Inf & UNK & December 27,1863 & June 27,1865 \\
\hline Fox & James & 32 NY Inf & 42 & August 27, 1862 & December 13,1862 \\
\hline Francke & Charles L. & 178 NY Inf & 22 & June 20,1863 & June 1,1865 \\
\hline Gough & Frank S. & 70 NY Inf & 27 & April 27, 1861 & April 15, 1862 \\
\hline Grizzle & A & $12 \mathrm{IL} \mathrm{Cav}$ & UNK & Unknown & March 30, 1866 \\
\hline Gullcross & Edward T & $5 \mathrm{IL} \mathrm{Cav}$ & UNK & September 6, 1861 & March 27, 1863 \\
\hline Gunn & George & $1 \mathrm{NY}$ Eng & 42 & August 15,1861 & January 21,1862 \\
\hline Heliner & Henry & 14 NY Cav & 27 & February 12,1864 & May 8,1864 \\
\hline Hill & James & $5 \mathrm{NY}$ Art & 22 & August 26, 1862 & March 4, 1863 \\
\hline Hinckley & Ambrose S. & $3 \mathrm{MA} \mathrm{Cav}$ & 32 & October 10,1862 & November 22,1864 \\
\hline Hoerhold & William & $150 \mathrm{NY}$ Inf & 28 & August 26, 1864 & October 20,1864 \\
\hline Hoffman & Louis & $31 \mathrm{NY}$ Inf & 28 & May 7,1861 & October 16,1861 \\
\hline Hustler & John & 174 NY Inf & 22 & November 8,1862 & April 7, 1863 \\
\hline Jackson & Thomas & 4 NY Cav & 22 & January 30,1863 & February 29,1864 \\
\hline Jacot & Peter & $16 \mathrm{IL} \mathrm{Cav}$ & UNK & January 31,1863 & July 31,1864 \\
\hline Johnson & Henry & 33 IL Inf & UNK & August 21,1861 & September 19,1861 \\
\hline Kelly & Barney & 3 CA Inf & UNK & November 28,1864 & March 20, 1865 \\
\hline Kimberly & Frank & 157 NY Inf & 33 & August 20, 1862 & July 12,1863 \\
\hline Koch & Simon & $10 \mathrm{IL}$ Cav & UNK & September 28,1861 & June 1,1862 \\
\hline Lindsay & Samuel & $85 \mathrm{NY}$ Inf & 18 & August 26, 1861 & September 29,1863 \\
\hline Lyon & Levi & $3 \mathrm{NY}$ Art & 45 & September 3, 1864 & December 5, 1864 \\
\hline
\end{tabular}




\begin{tabular}{|c|c|c|c|c|c|}
\hline Matlely & Conrad & $118 \mathrm{IL}$ Inf & UNK & March 15, 1865 & May 12,1865 \\
\hline McCann & John & 192 NY Inf & 25 & January 31,1865 & June 13,1865 \\
\hline McDougall & Frederick & 2 CA Inf & UNK & September 2, 1861 & March 13, 1862 \\
\hline McKinzie & Samuel & 14 IL Inf & UNK & May 25,1861 & May 25, 1863 \\
\hline McMahon & James & 9 CT Inf & UNK & September 5, 1861 & August 7, 1862 \\
\hline Miller & Charles & $5 \mathrm{NY}$ Art & 24 & October 24,1864 & April 19, 1865 \\
\hline Mitchell & John & 23 NY Cav & 18 & January 23, 1863 & April 2, 1863 ? \\
\hline Mosher & Howard C. & 177 NY Inf & 18 & November 10,1862 & July 5,1863 \\
\hline Oakley & Gilbert & 2 NY Cav & 20 & August 21, 1861 & September 6, 1862 \\
\hline O'Donahue & Dennis & 157 NY Inf & 27 & August 22,1862 & April 24, 1864 \\
\hline Olds & Philander & 154 NY Inf & 34 & September 1,1862 & June 20, 1863 \\
\hline Paff & Henry & 77 IL Inf & UNK & August 14,1862 & July 11,1863 \\
\hline Peterson & Carl & $31 \mathrm{NY}$ Inf & 26 & May 2,1861 & April 11, 1863 \\
\hline Peterson & Thomas & $56 \mathrm{NY}$ Inf & 29 & September 19,1864 & December 18,1864 \\
\hline Phillips & Albert & On. Ind. & 30 & October 21,1861 & June 12,1862 \\
\hline Pryor & Thomas & $2 \mathrm{NY} \mathrm{Cav}$ & 27 & September 7, 1864 & December 4, 1864 \\
\hline Rabus & John & $15 \mathrm{NY}$ Art & UNK & Unknown & March 18, 1866 \\
\hline Reed & Jason S. & $10 \mathrm{NY} \mathrm{Cav}$ & 22 & September 7, 1862 & January 11,1863 \\
\hline Regan & Thomas & 95 NY Inf & 30 & November 22,1861 & March 12, 1862 \\
\hline Reichardt & Julius & $68 \mathrm{NY}$ Inf & 27 & August 8,1861 & November 17,1863 \\
\hline Rhinehard & Ernest & $5 \mathrm{NY}$ Art & 28 & April 19, 1864 & August 2, 1864 \\
\hline Roche & Edward & $1 \mathrm{NY}$ MtRls & 18 & October 1,1861 & September 15,1864 \\
\hline Rockerath & Peter J. & 117 NY Inf & 44 & August 9,1862 & August 18,1862 \\
\hline Rotschild & Levi & 103 NY Inf & 32 & April 21, 1862 & July 1862 \\
\hline Schemedly & John & 97 NY Inf & 38 & August 7,1863 & October 19,1863 \\
\hline Schlund & Lewis & $8 \mathrm{IL} \mathrm{Cav}$ & UNK & September 20,1861 & September 12,1863 \\
\hline Schnemilch & William & 48 IL Inf & UNK & Unknown & July 20,1863 \\
\hline Schrafado & Joseph & $5 \mathrm{NY}$ Art & 24 & December 30, 1863 & May 7,1864 \\
\hline Scott & James & 15 NY Eng & 25 & November 25,1861 & August 11,1863 \\
\hline Seymour & George B. & $81 \mathrm{NY}$ Inf & 29 & December 7, 1864 & April 4, 1865 \\
\hline Smiley & R. Milton & 77 IL Inf & UNK & August 9, 1862 & June 6,1865 \\
\hline Smith & Thomas & 99 NY Inf & 26 & June 14,1861 & November 30,1861 \\
\hline Snell & Henry & $11 \mathrm{IL} \mathrm{Cav}$ & UNK & March 31, 1864 & September 19, 1865 \\
\hline Starkey & Frederick & $11 \mathrm{NY} \mathrm{Cav}$ & 33 & May 17,1862 & June 13,1863 \\
\hline Steede & Edward & $2 \mathrm{CA} \mathrm{Cav}$ & UNK & July 17,1864 & November 12,1865 \\
\hline Thompson & William & $18 \mathrm{NY} \mathrm{Cav}$ & 25 & December 2,1863 & February 15,1864 \\
\hline Tierney/Tumey & George B. & $2 \mathrm{CA} \mathrm{Cav}$ & UNK & October 7, 1862 & October 27,1864 \\
\hline Treat & Noyes & 15 CT Inf & UNK & August 11,1862 & February 15,1863 \\
\hline Trust & Daniel & $1 \mathrm{NY}$ Eng & 41 & May 11,1863 & March 5, 1864 \\
\hline Unknown & Unknown & Unknown & UNK & Unknown & December 13,1862 \\
\hline Vimpany & Charles & $12 \mathrm{IL} \mathrm{Cav}$ & UNK & December 30, 1861 & November 19,1864 \\
\hline Vossick & Henry & $10 \mathrm{IL} \mathrm{Cav}$ & UNK & August 26, 1861 & July 20, 1863 \\
\hline Wallingsford & James E. & $125 \mathrm{IL} \mathrm{Inf}$ & UNK & August 10,1862 & August 10,1863 \\
\hline Weise & Robert & $1 \mathrm{NY}$ Cav & 22 & February 29,1864 & March 17, 1864 \\
\hline Wellington & Kimball & $161 \mathrm{NY}$ Inf & 31 & August 22, 1862 & June 25,1863 \\
\hline Wenzier & Conrad & 48 NY Inf & UNK & Unknown & 1864 \\
\hline Westfall & Jerome & $70 \mathrm{NY}$ Inf & UNK & September 8,1862 & November 25, 1862 \\
\hline Wilber & Edwin & 44 NY Inf & UNK & Unknown & February 5, 1864 \\
\hline Wilkinson & William & $23 \mathrm{IL}$ Inf & UNK & April 11, 1865 & June 26,1865 \\
\hline
\end{tabular}




\begin{tabular}{|l|l|l|l|l|l|}
\hline William & John & 12 IL Inf & UNK & August 23, 1861 & May 18, 1862 \\
\hline Williams & John & 5 CT Inf & UNK & July 22, 1861 & February 28, 1862 \\
\hline Wing & Joseph B. & 2 CA Inf & UNK & November 6, 1861 & March 21, 1862 \\
\hline Winne & James & 2 CA Cav & UNK & September 23, 1861 & May 8, 1862 \\
\hline & & & & & $\begin{array}{l}\text { around February 13, } \\
\text { Witt Van Horkmburg }\end{array}$ \\
Unknown & 157 NY Inf & UNK & Unknown & February 3, 1863 \\
\hline Woldert & Adam & 14 CT Inf & UNK & July 23, 1862 & August 11, 1861 \\
\hline Younger & John & 32 NY Inf & 34 & April 25, 1861 & March 18, 1863 \\
\hline Youngs & Matthew & 143 NY Inf & 28 & August 13, 1862 & August 31, 1863 \\
\hline Zenkel & John & 8 IL Inf & UNK & August 19, 1861 & December 13, 1863 \\
\hline Zink & Bernhardt & 16 IL Cav & UNK & March 10, 1863 & Decen \\
\hline Zoller & Stephen & 15 NY Art & 37 & September 9, 1863 & August 31, 1864 \\
\hline
\end{tabular}

Inf - Infantry

Cav - Cavalry

Art - Artillery

MtRls - Mounted Rifles

Eng - Engineers

On. Ind. - Oneida Independent Company Cavalry 


\section{Bibliography}

\section{Manuscripts}

Austin, Matthew S. Letters. SoldierStudies.org.

Bates, Delavan. Letters. SoldierStudies.org.

Blakeman, J. Henry. Letters. SoldierStudies.org.

Carr, Austin. Diary (excerpted transcript). Army Heritage and Education Center, Carlisle, PA. The Harrisburg Civil War Round Table Collection, Box 7.

Chapin, Nelson. Letters. Army Heritage and Education Center, Carlisle, PA. Civil War Times Illustrated Collection, Box 5.

Christie, William G. Letters. SoldierStudies.org.

Collins, William H. Letters. SoldierStudies.org.

Elliott, James Peters. Letters. SoldierStudies.org.

Fell, Albinus R. Letters. SoldierStudies.org.

Freeman, Warren H. Letters. SoldierStudies.org.

Kellog, Henry C. Letters. SoldierStudies.org.

Lynch, Charles H. Diary. SoldierStudies.org.

Lyon, William P. Letters. SoldierStudies.org.

Matteson, Justus G. Letters. SoldierStudies.org.

McNeal, James B. Letters. SoldierStudies.org.

Morgan, Hance. Diary. Army Heritage and Education Center, Carlisle, PA. Civil War Times Illustrated Collection, Box 17.

Norton, O.W. Letters. SoldierStudies.org.

Phillips, William Beynon. Letters. SoldierStudies.org. 
Plimpton, Homer A. Letters. SoldierStudies.org.

Prutzman, Joseph. Letters. SoldierStudies.org.

Rastall, John E. Letters. SoldierStudies.org.

Root, Augustus I. Letters. SoldierStudies.org.

Smith, Stephen H. Diary. Army Heritage and Education Center, Carlisle, PA. Civil War Miscellaneous Collection, Box 96.

Tiedman, Charles H. Diary of Charles H. Tiedman, "D” Co. $178^{\text {th }}$ Regt. N.Y. Volunteers. Army Heritage and Education Center, Carlisle, PA. Civil War Miscellaneous Collection, Box 103.

Wills, Charles Wright. Letters. SoldierStudies.org.

Wilson, Jim. Letters. SoldierStudies.org.

\section{Published Primary Sources}

Adjutant General. Massachusetts Soldiers, Sailors, and Marines in the Civil War.

Norwood, MA: The Norwood Press, 1932-1933. Ancestry.com.

Annual Report of the Adjutant-General of the State of New York. Albany: printers vary, dates vary. http://dmna.state.ny.us/historic/mil-hist.htm.

Barr, Thomas F. "Cost and Compensations of the War." In Military Essays and Recollections: papers read before the Commandery of the State of Illinois, Military Order of the Loyal Legion of the United States, Volume I. Chicago: A.C. McClurg and Company, 1891.

Barth, Gunter, ed. All Quiet On the Yamhill: The Civil War in Oregon, The Journal of Corporal Royal A. Bensell, Company D, Fourth California Infantry. Eugene, OR: University of Oregon Books, 1959. 
Bee, Robert L., ed. The Boys From Rockville: Civil War Narratives of Sgt. Benjamin Hirst, Company D, $14^{\text {th }}$ Connecticut Volunteers. Knoxville: The University of Tennessee Press, 1998.

Benton, Charles E. As Seen From the Ranks: A Boy in the Civil War. New York: G.P. Putnam's Sons, 1902.

Brown, Augustus Cleveland. The Diary of a Line Officer. 1906. American Civil War Diaries and Letters, Accessed February 3, 2011.

Brumleve, Patrick, ed. The Letters of James Evans, $109^{\text {th }}$ Illinois Volunteer Infantry Regiment, August 23, 1862 to April 18, 1863. Union County Historical \& Genealogy Society, 1996.

California Adjutant General's Office. Records of California Men in the War of the Rebellion, 1861 to 1867. Compiled by Brig.-Gen. Richard H. Otten. Sacramento: J. D. Young, 1890. Google Books

Calvert, Henry Murray. Reminiscences of a Boy in Blue, 1862-1865. New York: G.P. Putnam's Sons, 1920.

Comper, Frances M. M., ed. The Books of the Craft of Dying and Other Early English Tracts Concerning Death, Taken from Manuscripts and Printed in the British Museum and Bodleian Libraries, Now First Done into Modern Spelling and Edited by Frances M. M. Comper, with a Preface by the Rev. George Congreve, S. S. J. E. New York: Longmans, Green, and Co., 1917. 
Cook, S.G., and Charles E. Benton, ed. The "Dutchess County Regiment" $\left(150^{\text {th }}\right.$ Regiment of New York State Volunteer Infantry) in the Civil War; Its Story as Told by its Members. Danbury, CT: The Danbury Medical Printing Co., Inc., 1907.

Cunningham, Michael R. "Follow me to victory or death": The diaries and letter of Captain Henry Martin Kellogg, 33 ${ }^{\text {rd }}$ Illinois Volunteer Infantry. 1993.

Dodge, William Sumner. A Waif of the War; Or, the History of the Seventy-fifth Illinois Infantry, Embracing the Entire Campaigns of the Army of the Cumberland. Chicago: Church and Goodman, Publishers, 1866.

Earnest, Sally Andrews, ed. Letters of Stephen Tuppet Andrews of the $85^{\text {th }}$ New York Volunteers, Company F, to Miss Margaret Little, Franklinville, New York, August 28, 1861 to March 28, 1865 during the Civil War. Pittsboro, NC: The Town House Press, 1998.

Evans, Thomas H. "The Cries of the Wounded were Piercing and Horrible," Civil War Times Illustrated 7 (July 1968): 28-38.

Fisk, Joel C., and William H.D. Blake. A Condensed History of the $56^{\text {th }}$ Regiment New York Veteran Volunteer Infantry, Which was a Part of the Organization Known as the "Tenth Legion" in the Civil War, 1861-1865. Newburgh Journal Printing House and Book Bindery, 1906.

Gavin, William Gilfillan. Infantryman Pettit: The Civil War Letters of Corporal Frederick Pettit, Late of Company C, $100^{\text {th }}$ Pennsylvania Veteran Volunteer Infantry Regiment “The Roundheads,” 1862-1864. Shippensburg, PA: White Mane Publishing Company, Inc., 1990. 
Gould, Benjamin Apthorp. Investigations in the Military and Anthropological Statistics of American Soldiers. New York: Published for the U.S. Sanitary Commission, by Hurd and Houghton; Cambridge: Riverside Press, 1869.

Hosmer, James Kendall. The Color-Guard: Being a Corporal's Notes of Military Service in the Nineteenth Army Corps. Boston: Walker Wise and Co., 1864. American Civil War Letters and Diaries, accessed December 1, 2011.

“Illinois Civil War Muster and Descriptive Rolls Database.” Illinois State Archives. www.ilsos.gov/genealogy/CivilWarController. Accessed February 17, 2012.

Illinois. Military and Naval Department, Jasper N. Reece, and Isaac Hughes Elliott. Report of the Adjutant-General of the State of Illinois. Springfield: Phillips Bros, State Printers, 1900- 1901. Google Books.

Jaques, John W. Three Years' Campaign of the Ninth, N.Y.S.M., During the Southern Rebellion. New York: Hilton \& Co., Publishers, 1865.

Jones, William E. The Military history of the One Hundred and Sixty-first New York Volunteers, Infantry, from August 15 ${ }^{\text {th }}, 1862$ to October 17, 1865 (1865). Army Heritage and Education Center, Carlisle, PA. U.S. Army Military History Research Collection.

Kimball, Charles B. History of Battery “A,” First Illinois Light Artillery Volunteers. Chicago: Cushing Printing Company, 1899. http://babel.hathitrust.org. Lyth, Alfred. "The Andersonville Diary of Private Alfred Lyth.” Niagra frontier 8, no. 1 (1961): 14, 19-24. 
Marshall, Albert O’Connell. "Memoir of Albert O'Connell Marshall.” In Army Life from a Soldier's Journal: Incidents, Sketches and Record of a Union Soldier's Army Life, in Camp and Field, 1861-1864. Joliet, IL: A. O. Marshall, 1883. American Civil War Diaries and Letters, Accessed February 3, 2011.

Meyer, Henry C. Experiences with the New York Cavalry: Under Bayard, Gregg, Kilpatrick, Custer, Raulston \& Newberry 1862-1864. Oakpost Ltd, 2010.

Nash, Eugene Arus. A History of the Forty-fourth Regiment New York Volunteer Infantry in the Civil War, 1861-1865. Chicago: R.R. Donnelley \& Sons Company, 1911.

Partridge, Charles Addison. History of the Ninety-Sixth Regiment, Illinois Volunteer Infantry. Chicago: Historical Society of the Regiment, 1887. GoogleBooks, accessed December 2, 2011.

Phisterer, Frederick. Statistical Record of the Armies of the United States. New York: Charles Scribner's Sons, 1883.

Porter, Burton B. One of the People: His Own Story. Burton B. Porter, 1907.

Powers, Elvira J. Hospital Pencilings: Being a Diary While in Jefferson General Hospital, Jeffersonville, Indiana and Others at Nashville, Tennessee as Matron and Visitor. Boston, MA: E. L. Mitchell, 1866. American Civil War Diaries and Letters, Accessed February 3, 2011.

Preston, N.D. History of the Tenth Regiment of Cavalry, New York State Volunteers, August, 1861, to August, 1865. New York: D. Appleton and Company, 1892. US Army Heritage and Education Center, Carlisle, PA. 
Records of Service of Connecticut Men in the army and navy of the United States during the War of the Rebellion. Hartford, CT: Press of the Case, Lockwood \& Brainard Co., 1889. Ancestry. com.

Smith, Thomas West. The Story of a Cavalry Regiment, "Scotts' 900, "Eleventh New York Cavalry, From the St. Lawrence River to the Gulf of Mexico, 1861-1865. Chicago: W.B. Conkey Co., 1897.

Throne, Mildred, ed. The Civil War Diary of Cyrus F. Boyd, Fifteenth Iowa Infantry, 1861-1863. Baton Rouge: Louisiana State University, 1953.

VanWyck, Richard T. A War to Petrify the Heart: The Civil War Letters of a Duchess County, N.Y. Volunteer. Edited by Virginia Hughes Kaminsky. Hensonville, NY: Black Dome Press, 1997. US Army Heritage and Education Center, PA.

Wheeler, William. Letters of William Wheeler of the Class of 1855, Y.C. 1875. American Civil War Letters and Diaries, accessed December 1, 2011.

Wilkeson, Frank. Recollections of a Private Soldier in the Army of the Potomac. New York and London: G.P. Putnam's Sons, 1887.

Wills, Charles Wright. "Diary of Charles Wright Wills, June, 1861," in Army Life of an Illinois Soldier: Including a Day by Day Record of Sherman's March to the Sea: Letters and Diary of the Late Charles Wright Wills, Private and Sergeant $8^{\text {th }}$ Illinois Infantry, Lieutenant and Battalion Adjutant $7^{\text {th }}$ Illinois Cavalry, Captain, Major and Lieutenant Colonel 103 ${ }^{\text {rd }}$ Illinois Infantry, Compiled by Mary E. Kellogg. Globe Print Co., 1906. Accessed February 3, 2011, American Civil War Diaries and Letters. 
Wilson, Byron B. Soldiers' Letters, from Camp, Battle-field and Prison. New York: Bunce \& Huntington, 1865. American Civil War Letters and Diaries, accessed December 1, 2011.

Winschel, Terrence J. The Civil War Diary of a Common Soldier: William Wiley of the $77^{\text {th }}$ Illinois Infantry. Baton Rouge: Louisiana State University Press, 2001.

\section{Secondary Sources}

Beaty, Nancy Lee. The Craft of Dying: A Study in the Literary Tradition of the Ars Moriendi in England. New Haven: Yale University Press, 1970.

Bell, Richard James. "Do Not Despair: The Cultural Significance of Suicide in America, 1780-1840.” PhD Dissertation, Harvard University, 2006.

Blackwell, Samuel M., Jr. In The First Line of Battle: The $12^{\text {th }}$ Illinois Cavalry in the Civil War. Dekalb, IL: Northern Illinois University Press, 2002.

Bracy, Isabel, comp. $157^{\text {th }}$ New York Volunteer (Infantry) Regiment, 1862-1865, Madison and Cortland Counties, New York. Interlaken, NY: Heart of the Lakes Publishing, 1991.

Bryan, Craig J. "The Clinical Utility of a Brief Measure of Perceived Burdonsomeness and Twarted Belongness for the Detection of Suicidal Military Personnel." Journal of Clinical Psychology 67, no. 10 (2011): 981-992.

Bryan, Craig J., et al, "Combat Experience and the Acquired Capability for Suicide." Journal of Clinical Psychology 66, no. 10 (2010): 1044-1056.

Burgess-Jackson, Keith. "The Legal Status of Suicide in Early America: A Comparison with the English Experience.” Wayne Law Review 29, no. 57 (1982): 57-87. 
Cressy, David. Birth, Marriage, and Death: Ritual, Religion, and the Life-Cycle in Tudor and Stuart England. New York: Oxford University Press, 1997.

Dean, Eric T., Jr. Shook Over Hell: Post-Traumatic Stress, Vietnam, and The Civil War. Cambridge, MA: Harvard University Press, 1997.

Dunkleman, Mark H. Brothers One and All: Esprit de Corps in a Civil War Regiment. Baton Rouge: Louisiana State University Press, 2004.

Durkheim, Emile. Suicide: A Study in Sociology. Translated by John A. Spaulding and George Simpson. Edited by George Simpson. Glencoe, IL: The Free Press, 1951.

Faust, Drew Gilpin. This Republic of Suffering: Death and the American Civil War. New York: Alfred A. Knopf, 2008.

Foote, Lorien. The Gentlemen and the Roughs: Manhood, Honor and Violence in the Union Army. New York: New York University Press, 2010.

Greenberg, Amy S. Manifest Manhood and the Antebellum American Empire. New York: Cambridge University Press, 2005.

Hess, Earl J. The Union Soldier in Battle: Enduring the Ordeal of Combat. Lawrence, KS: The University Press of Kansas, 1997.

Howe, Daniel Walker. What Hath God Wrought: The Transformation of America, 18151848. New York: Oxford University Press, 2007.

Joiner, Thomas. Why People Die By Suicide. Cambridge: Harvard University Press, 2005. Kushner, Howard I. Self-Destruction in the Promised Land: A Psychocultural Biology of American Suicide. New Brunswick: Rutgers University Press, 1989.

Linderman, Gerald F. Embattled Courage: The Experience of Combat in the American Civil War. New York: The Free Press, 1987. 
Mahood, Wayne. The Plymouth Pilgrims: A History of the Eighty-Fifth New York Infantry in the Civil War. Hightstown, NJ: Longstreet House, 1991.

Marvel, William. Andersonville: The Last Depot. Chapel Hill: The University of North Carolina Press, 1994.

McPherson, James M.For Cause and Comrades: Why Men Fought in the Civil War. New York: Oxford University Press, 1997.

Minois, Georges. History of Suicide: Voluntary Death in Western Culture. Baltimore: The Johns Hopkins University Press, 1999.

Mitchell, Reid. Civil War Soldiers: Their Expectations and Their Experiences. New York: Viking Penguin Inc., 1988.

---. The Vacant Chair: The Northern Soldier Leaves Home. New York: Oxford University Press, 1993.

Noll, Mark A. America's God: From Jonathan Edwards to Abraham Lincoln. New York: Oxford University Press, 2002.

Parks, George E. "The Long Winter”; Being a Factual Narrative of One Story of the “Unusual” $109^{\text {th }}$ Regiment Volunteer Infantry of State of Illinois, 1862-1863. Published in commemoration of the Centennial of the $109^{\text {th }}$ Regiment of Illinois Volunteer Infantry, 1963.

Pizarro, Judith, Roxane Cohen Silver, and JoAnn Prause, "Physical and Mental Health Costs of Traumatic War Experiences Among Civil War Veterans," Arch Gen Psychiatry 63 (Feb 2006):193-200.

Rable, George C. God's Almost Chosen People: A Religious History of the American Civil War. Chapel Hill: The University of North Carolina Press, 2010. 
---. "It Is Well That War Is So Terrible: The Carnage at Fredericksburg." In The Fredericksburg Campaign: Decisions on the Rappahannock, 48-79. Edited by Gary W. Gallagher. Chapel Hill: University of North Carolina Press, 1995.

Rolfs, David. No Peace for the Wicked: Northern Protestant Soldiers and the American Civil War. Knoxville: The University of Tennessee Press, 2009.

Saum, Lewis O. "Death in the Popular Mind of Pre-Civil War America." American Quarterly 26, no. 5 (December 1974): 477-495.

---. The Popular Mood of Pre-Civil War America. Westport, CT: Greenwood Press, 1980.

Schantz, Mark S. Awaiting the Heavenly Country: The Civil War and America's Culture of Death. Ithaca: Cornell University Press, 2008.

Sheehan-Dean, Aaron. Why Confederates Fought: Family \& Nation in Civil War Virginia. Chapel Hill: The University of North Carolina Press, 2007.

Shneidman, Edwin S. The Suicidal Mind. New York: Oxford University Press, 1996.

South, Fred S. It Never Recoiled: A History of the Seventy-Fifth Illinois Volunteer Infantry. Prophetstown, IL: 1995.

Stout, Harry. Upon the Altar of the Nation: A Moral History of the American Civil War. New York: Viking, 2006.

Wiley, Bell I. The Life of Billy Yank: The Common Soldier of the Union. New York: The Bobbs-Merrill Company, 1951.

Woodworth, Steven E. While God is Marching On: The Religious World of Civil War Soldiers. Lawrence, KS: University Press of Kansas, 2001. 